\title{
Hervorming en modernisering van het strafprocesrecht: de inrichting van het vooronderzoek
}

\author{
Philip Traest*
}

\section{Inleiding}

De keuze van het thema voor de jaarvergadering 2017 is in hoge mate geïnspireerd door de noodzaak van een aanpassing van het strafprocesrecht (en in het bijzonder de bepalingen die betrekking hebben op het vooronderzoek) aan de actuele noden enerzijds en de daarmee gepaard gaande noodzaak om welbepaalde en soms fundamentele keuzes te moeten maken omtrent de toekomstige regeling anderzijds. Dit laatste element verklaart logischerwijze de moeilijkheden van dergelijke hervorming en modernisering.

In tegenstelling tot wat voor Nederland geldt, heeft het Belgische strafprocesrecht sedert het ontstaan van de Belgische staatsstructuur nooit het voorwerp uitgemaakt van een grondige en algemene hervorming of modernisering. Waar vanzelfsprekend op bepaalde tijdstippen de tekst van het wetboek werd aangepast en vervolledigd en op die manier werd aangepast aan de noden van de tijd dringt zich de - jammere - vaststelling op dat de Belgische wetgever er tot op vandaag nooit in geslaagd is een volledig nieuw wetboek van strafprocesrecht ingang te doen vinden.

Het hoeft dan ook geen verwondering te wekken dat de vorige maar vooral de huidige minister van Justitie - respectievelijk mevrouw Turtelboom en de heer Geens - de wens hebben uitgedrukt te komen tot de redactie van een nieuw wetboek van strafprocesrecht.

Nadat in het regeerakkoord van de toenmalige federale regering van I december 201 I de intentie tot uitdrukking werd gebracht om een vernieuwd Wetboek van Strafvordering op te stellen werd door de vorige minister van Justitie in haar beleidsnota van 27 december 2012 aangegeven dat er nood is aan een onderzoek naar de knelpunten die de Belgische strafprocedure inefficiënt en ineffectief maken. ${ }^{\mathrm{I}}$ Als gevolg hiervan werd aan de Universiteit Gent verzocht dergelijk

\footnotetext{
* Prof. dr. Philip TRAest is buitengewoon hoogleraar in de vakgebieden strafrecht en strafvordering aan de Universiteit Gent (faculteit Recht en Criminologie, vakgroep criminologie, strafrecht en sociaal recht)

I Algemene beleidsnota justitie, Parl. St. Kamer, 2012-I3, nr. 2586/27, I6.
} 
onderzoek te voeren. Dit onderzoek werd gevoerd tussen augustus 2013 en november $2014 .^{2}$

De huidige minister van Justitie heeft sedert zijn aantreden in 20I4 nieuwe initiatieven ontwikkeld waaruit blijkt dat het hem menens is met een grondige hervorming van het strafrecht en het strafprocesrecht.

Naast andere domeinen en disciplines van het recht blijkt uit de voornemens van de minister dat hij zowel een nieuw wetboek van strafrecht ${ }^{3}$ als een nieuw wetboek van strafprocesrecht wil ingevoerd zien voor het einde van de lopende legislatuur.

Bij ministerieel besluit van 30 oktober $2015^{4}$ werden twee commissies aangesteld, bestaande uit academici en magistraten. De ene commissie werd belast met een hervorming van het strafrecht terwijl de tweede commissie werd belast met een hervorming van het strafprocesrecht. Aan elk van deze commissies werd, ieder wat haar betreft, de opdracht gegeven om een oriëntatienota uit te werken en vervolgens een voorstel tot hervorming van het betrokken wetboek uit te werken.

De minister van Justitie heeft er ook voor gekozen om in afwachting van een grondige hervorming van het strafrecht en het strafprocesrecht een aantal meer punctuele onderdelen van het materieel en formeel strafrecht te hervormen. Het gaat hierbij telkens om hervormingen waarvan hij van oordeel is dat deze geen fundamentele keuze impliceren en derhalve ook geen voorafname kunnen uitmaken op een meer grondige hertekening van het strafprocesrecht die over enkele jaren zal volgen.

In dit kader werden dan ook enkele "potpourri"-wetten goedgekeurd waarvan de tweede betrekking heeft op het strafrecht en strafprocesrecht. ${ }^{5}$

De aanstelling van de vermelde commissie Strafprocesrecht heeft geresulteerd in een nota "krijtlijnen voor een nieuw wetboek van strafprocesrecht" die in een aantal fora en onder meer ook in de commissie voor de Justitie van de Kamer van Volksvertegenwoordigers werd toegelicht op I4 oktober 20I6. In de Algemene beleidsnota van 3 november 2016 werd door de minister van Justitie de essentie van de voorstellen weergegeven en werd medegedeeld dat de redactie van de

2 Voor het rapport: Ph. Traest, G. Vermeulen, W. De Bondt, T. Gombeer, S. RaAts \& L. VAN PUYENBROECK, Scenario's voor een nieuwe Belgische strafprocedure. Een praktijkgericht knelpuntenonderzoek, IRCP research series, vol. 49, Antwerpen, Maklu, 582 p.

3 Het huidige Belgische Strafwetboek dateert van 1867.

4 BS 29 december 2015.

5 Wet van 5 februari 2016 tot wijziging van het strafrecht en de strafvordering en houdende diverse bepalingen inzake justitie, BS I9 februari 2016. Opgemerkt dient te worden dat ook in de eerste potpourriwet (Wet van I9 oktober 20I5 houdende wijziging van het burgerlijk procesrecht en houdende diverse bepalingen inzake justitie, BS 22 oktober 2015) enkele bepalingen staan die betrekking hebben op het strafprocesrecht, bijvoorbeeld in zoverre met betrekking tot de rechterlijke organisatie het beginsel van de alleenzetelende rechter in strafzaken in eerste aanleg nog wordt versterkt. 
wetteksten kan worden aangevat. ${ }^{6}$ Essentieel is hierbij onder meer dat één soort onderzoek wordt ingevoerd onder de leiding van het Openbaar Ministerie en onder de controle van een rechter, die echter niet langer zelf het onderzoek zal leiden maar die tegelijk versterkt zal worden in zijn controlerende en rechtsprekende functie ten aanzien van het vooronderzoek.

Deze bijdrage beoogt dan ook in dit kader enkele elementen aan te reiken die nuttig kunnen zijn om het strafprocesrecht te moderniseren zonder daarbij pasklare en volledig uitgewerkte oplossingen aan te bieden.

\section{$2 \quad$ Een terugblik}

Het wetboek dat in België tot de dag van vandaag wordt gebruikt is nog steeds de Franse Code d'instruction criminelle uit I808.7 In I789 was de periode van het intermediaire recht gestart, die duurde tot de Napoleontische codificaties en gekenmerkt werd door een - chronologisch - eerste antiautoritaire tendens waar de accusatoire procesvorm centraal stond, gevolgd door een autoritaire tendens waar opnieuw een wending naar een meer inquisitoire procedure kon opgetekend worden. ${ }^{8}$ Deze beide tendenzen werden uiteindelijk met elkaar verzoend in de Code d'instruction criminelle van $1808 .{ }^{9}$

Nadat in I8Io het Strafwetboek in werking was getreden werd in I8II ook de Code d'instruction criminelle in werking gesteld. Zeer algemeen kan worden gesteld dat dit wetboek twee procestypes met elkaar combineerde. Enerzijds was het vooronderzoek in hoge mate inquisitoir (geheim, niet-tegensprekelijk en schriftelijk) terwijl anderzijds het onderzoek ter terechtzitting van het vonnisgerecht sterk accusatoir gekleurd was (openbaar, tegensprekelijk en mondeling).

Gedurende de periode waarin de Belgische provincies deel uitmaakten van het Koninkrijk der Nederlanden (I8I5-I830) wijzigde de toestand niet, behalve dat de jury werd afgeschaft.

Na de Belgische onafhankelijkheid bleef de Code d'instruction criminelle van kracht doch werd in artikel I39 van de Belgische Grondwet bepaald dat zo spoedig mogelijk nieuwe wetboeken dienden te worden uitgewerkt. Het in voege laten van de Code d'instruction criminelle was aldus slechts een noodoplossing doch is in werkelijkheid van veel langere duur gebleken. ${ }^{\text {Io }}$

6 Algemene beleidsnota Justitie, Parl. St. Kamer, 20I6-I7, nr. 54-2III/O2I, p. I9-20.

7 Op het ogenblik dat dit Napoleontische wetboek werd uitgevaardigd maakte het latere België deel uit van het Franse rijk.

8 J. D'HAEnENS, Belgisch strafprocesrecht, Gent, Story-Scientia, I985, I2-I4.

9 Met de redactie van de Code d'instruction criminelle werd een aanvang gemaakt in I8or.

Io De op zich terechte vaststelling van Faustin Hélie dat de strafprocedure "l'un des problèmes les plus difficiles que la législation à résoudre" is, rechtvaardigt nochtans niet dat het in België tot de dag van vandaag niet gelukt is een nieuw wetboek van strafprocesrecht in voege te laten treden, waar zulks in de omringende landen zoals Nederland en Frankrijk wel gelukt is, respectievelijk in I838 en I92I en in 1958 . 
Reeds van bij de aanvang werd dit wetboek aan stevige kritiek onderworpen. Waar deze tekst volgens sommigen een monument was, werd door anderen opgemerkt dat het wetboek reeds archaïsch was in I808, gelet op de overname van sommige bepalingen uit de tijd van Lodewijk XIV en de Ordonnance criminelle van I670. ${ }^{\text {II }}$ Volgens CORNIL was dit wetboek het slechtst opgestelde van de Napoleontische wetboeken. ${ }^{\text {I2 }}$

Niettegenstaande het wetboek weinig of geen algemene principes bevat, weinig definities en weinig structuur vestigden sommigen er de aandacht op dat het wetboek al met al meer dan I50 jaar - en ondertussen meer dan 200 jaar - dienst heeft gedaan. ${ }^{33}$ Dit laatste valt niet te loochenen doch het is zeer de vraag of zulks een gevolg is van de intrinsieke kwaliteit van het wetboek dan wel van de veelvuldige noodzakelijke, beperkte en punctuele aanpassingen ${ }^{\mathrm{I}}$ die aan het wetboek werden aangebracht enerzijds en de rol van de rechtspraak anderzijds. Talrijke lacunes en onnauwkeurigheden werden immers in de loop der tijden door de rechtspraak weggewerkt. ${ }^{15}$ Het Belgische strafprocesrecht heeft dan ook een hoog pretoriaans gehalte.

Als gevolg van de hoger geschetste bedoeling van de grondwetgever werden sedert I830 dan ook een aantal initiatieven genomen om het strafprocesrecht te hervormen. Waar de bedoeling van de grondwetgever en het betrokken artikel $\mathrm{I} 39-\mathrm{II}^{\circ}$ van de Grondwet er vooral uit bestond om de bestaande codificaties aan te passen kan worden vastgesteld dat de na I830 genomen initiatieven in werkelijkheid een grondige hervorming van het strafprocesrecht nastreefden. ${ }^{16}$

In het bestek van deze bijdrage volstaat het kort te verwijzen naar de diverse pogingen om het strafprocesrecht te hervormen.

In I850 werd door de regering een commissie aangesteld doch van de door deze commissie opgestelde teksten werd enkel een voorlopigehechteniswet aangenomen in I852. In 1869 werd de samenstelling van deze commissie bevestigd waarna niet minder dan drie voorontwerpen werden ingediend tussen I877 en I879. Daarvan werd enkel het eerste gestemd, wat dan heeft geleid tot de wet van I7 april I878 houdende de Voorafgaande titel van het Wetboek van Strafvordering. ${ }^{17}$ Hoewel in

II Aldus Garraud in zijn Traité de l'instruction criminelle, Paris, Sirey, I907-I9I2, 96.

I2 L. CORNIL, "De la nécessité de rendre à l'instruction préparatoire le caractère légal qu'elle a perdu”, Rev. dr. pén., I93I, 8I2.

I3 H. BEKAERT, La manifestation de la vérité dans le procès pénal, Brussel, Bruylant, I972, 60.

I4 Bij wijze van voorbeeld kan hierbij worden verwezen naar de aanpassingen die ingevolge de Salduzrechtspraak van het EHRM (o.a. EHRM 27 november 2008, Salduz/Turkije) en de EU-Salduzrichtlijn (Richtlijn 20I3/48/EU van het Europees Parlement en de Raad van 22 oktober 2013) werden ingevoerd respectievelijk door de wet van I3 augustus 20II tot wijziging van het Wetboek van Strafvordering en van de wet van 20 juli I99o betreffende de voorlopige hechtenis, om aan elkeen die wordt verhoord en aan elkeen wiens vrijheid wordt benomen rechten te verlenen, waaronder het recht om een advocaat te raadplegen en door hem te worden bijgestaan (BS 5 september 20II) en de Wet van 2I november 2016 houdende bepaalde rechten van personen die worden verhoord (BS 24 november 2016).

I5 J. D'HAENENS, o.c., I4.

I6 J. D'HAENENS, o.c., I6.

I7 H. BEKAERT, La manifestation de la vérité dans le procès pénal, 43-44. 
deze voorafgaande titel een aantal belangrijke aangelegenheden wordt geregeld zoals de verjaring van de strafvordering, moet worden geconcludeerd dat de hele hervormingsdrift uiteindelijk slechts geleid heeft tot een dertigtal wetsartikelen. ${ }^{8}$

In 1902 werd door de toenmalige minister van Justitie Van den Heuvel een ontwerp in het parlement ingediend dat de hervormingsbeweging nieuw leven wilde inblazen en dat een aantal bepalingen bevatte met betrekking tot het gerechtelijk vooronderzoek. Het was de bedoeling om dit vooronderzoek een meer accusatoir karakter te geven. Dit wetsontwerp werd in het parlement nooit besproken, net zomin als het in I9or vrijwel gelijktijdig door de volksvertegenwoordigers Janson en Hymans ingediende wetsvoorstel.

Eenzelfde lot werd voorbehouden aan het in I9I4 ingediende ontwerp Servais, dat er eveneens toe strekte aan het vooronderzoek een meer tegensprekelijk karakter te verlenen.

Ten slotte werd in 1962 prof. H. Bekaert aangesteld als Koninklijk commissaris met als opdracht een voorontwerp van hervorming van de strafrechtspleging op te stellen. Dit heeft wel geleid tot een waardevol boek met belangrijke opvattingen die de uitgangspunten voor dergelijke hervorming zouden kunnen vormen ${ }^{\text {19 }}$ doch tot een werkelijke herziening van het Wetboek van Strafvordering is het niet gekomen.

Vervolgens bleef het stil tot I99I.

Bij besluit van de toenmalige minister van Justitie ${ }^{20}$ werd op 23 oktober I99I de commissie Strafprocesrecht ${ }^{21}$ opgericht. Deze commissie bestond uit professoren, magistraten en advocaten.

De oprichting van deze commissie was op haar beurt het gevolg van de aanbevelingen van de eerste parlementaire onderzoekscommissie belast met het onderzoek naar de wijze waarop in België de bestrijding van het banditisme en het terrorisme georganiseerd wordt. ${ }^{22}$ België was immers in de loop van de jaren tachtig van de vorige eeuw getroffen geworden door een aantal politiek gemotiveerde aanslagen enerzijds en een reeks bijzonder bloedige overvallen anderzijds. De besluiten en aanbevelingen van de vermelde parlementaire onderzoekscommissie waren voor de toenmalige regering de reden om in een verklaring van 5 juni $199 \mathrm{O}^{23}$ aan te kondigen een onderzoek te laten uitvoeren naar de hervorming van

I8 Deze artikelen vervingen de oorspronkelijke artikelen I tot en met 7 van de Code d'instruction criminelle.

I9 H. BEKAERT, La manifestation de la vérité dans le procès pénal, Brussel, Bruylant, I972.

20 Belgisch Staatsblad van ir november iggr.

2I Deze commissie werd al snel de 'commissie-Franchimont' genoemd naar de voorzitter van de commissie, de Luikse hoogleraar en advocaat Michel Franchimont.

22 Verslag van de parlementaire onderzoekscommissie naar de wijze waarop de bestrijding van het banditisme en terrorisme wordt georganiseerd, Parl. St. Kamer, 1989-9o, nr. 59/8, 59/9 en 59/10.

23 Regeringsverklaring van 5 juni I990, Parl. St. Senaat, I989-9o, p. 205I e.v. Zie hierbij tevens de memorie van toelichting bij het wetsontwerp tot verbetering van de strafrechtspleging in het 
het Wetboek van Strafvordering en in het bijzonder naar de bepalingen betreffende het opsporingsonderzoek en het gerechtelijk onderzoek.

Het is niet onbelangrijk de exacte opdracht van de commissie te vermelden, niet in het minst omdat de oprichting van deze commissie en de werkzaamheden ervan een belangrijke factor zijn geweest in de hervormingsbeweging die tot de dag van vandaag voortduurt. De commissie had als opdracht:

- de inventarisatie van de actuele problemen op het vlak van de strafrechtspleging;

- het aanwijzen van de hervormingen die bij voorrang moeten worden doorgevoerd, zonder vooruit te lopen op meer fundamentele keuzes;

- het inwinnen van informatie over de in het buitenland recent doorgevoerde hervormingen of in voorbereiding zijnde hervormingen;

- het formuleren van voorstellen als aanzet tot het maken van fundamentele keuzes inzake opsporings- en gerechtelijk onderzoek;

- in een latere fase, de voorbereiding van een ontwerp van wetboek van strafprocesrecht.

Het was dus van meet af aan duidelijk dat de commissie, wier mandaat in de regel in de tijd niet beperkt was, in twee tijden diende te werken, eerst dringende punctuele hervormingen in het vooronderzoek, vervolgens een nieuw wetboek van strafprocesrecht.

Het eerste deel van de opdracht heeft geleid tot de wet van I2 maart I998 tot verbetering van de strafrechtspleging in het stadium van het opsporingsonderzoek en het gerechtelijk onderzoek. ${ }^{24}$

De wet van 12 maart 1998 is de belangrijkste wijziging aan het Wetboek van Strafvordering sedert de invoering van de voorafgaande titel van dit wetboek in I878. Hoewel de wijzigingen enkel te situeren waren in het gerechtelijk onderzoek ${ }^{25}$ en het opsporingsonderzoek grotendeels ongemoeid werd gelaten werden de wijzigingen door menig rechtspracticus als verregaand of soms te verregaand beschouwd.

De algemene strekking van de wet van I2 maart I998 was er één van verhoging van de participatie van de partijen in het verloop van het gerechtelijk onderzoek. Aan de inverdenkinggestelde en de burgerlijke partij werden enkele rechten verleend. Zo kunnen deze partijen sedert 1998 aan de onderzoeksrechter reeds tijdens het onderzoek om inzage in het dossier verzoeken. De onderzoeksrechter kan dit weigeren doch hiertegen is hoger beroep mogelijk bij de kamer van inbeschuldigingstelling. ${ }^{26}$ Ook kunnen deze partijen de onderzoeksrechter verzoeken om bij-

stadium van het opsporingsonderzoek en het gerechtelijk onderzoek, Parl. St. Kamer, I996-97, nr. 857/I, I-3.

24 BS 2 april 1998 en in werking getreden op 2 oktober 1998.

25 Geleid door de onderzoeksrechter. Het opsporingsonderzoek, dat wordt geleid door de procureur des Konings, wordt in ruim 9o\% van de strafzaken aangewend. Wel dient te worden erkend dat het gerechtelijk onderzoek meestal voorkomt in de zwaarste strafzaken.

26 De kamer van inbeschuldigingstelling is een onderdeel van het hof van beroep. 
komende onderzoekshandelingen te stellen. Ook hier kan de onderzoeksrechter weigeren indien zulks hem niet nuttig lijkt doch ook in dit geval kunnen partijen in beroep gaan bij de kamer van inbeschuldigingstelling. Ten slotte kan iedereen die getroffen wordt door een opsporingshandeling met betrekking tot zijn goederen (bijv. een inbeslagneming) naargelang het geval aan de onderzoeksrechter of de procureur des Konings om de opheffing ervan verzoeken. Ook hier is hoger beroep bij de kamer van inbeschuldigingstelling mogelijk.

$\mathrm{Na}$ de indiening van het voorontwerp houdende de punctuele hervormingen werkte de commissie Strafprocesrecht verder aan het tweede deel van haar opdracht, met name de redactie van een nieuw wetboek van strafprocesrecht.

In september 1999 werd een tekst aan de minister van Justitie overhandigd. In september 200 I werd het hervormingsproces weer op gang getrokken door de opdracht van de toenmalige minister van Justitie aan de universiteiten van Gent en Luik om de destijds opgestelde tekst te actualiseren, gelet op de ondertussen gewijzigde wetgeving, en de tekst en de memorie van toelichting te herlezen in dit perspectief.

Op I7 september 2002 werd door de Commissie Strafprocesrecht de tekst van een voorontwerp van wetboek van strafprocesrecht aan de minister van Justitie overhandigd. ${ }^{27}$

De regering-Verhofstadt II heeft in haar regeringsverklaring in 2003 met geen woord over dit ontwerp gerept zodat kan geconcludeerd worden dat de indiening van deze tekst in het parlement klaarblijkelijk niet tot de prioriteiten van de regering behoorde.

Nochtans werd de tekst van het voorontwerp, zoals aan de minister van Justitie overhandigd, als wetsvoorstel in de Senaat ingediend op I3 januari $2004 \cdot{ }^{28} \mathrm{De}$ Commissie voor de Justitie van de Senaat onderzocht de tekst tijdens talrijke vergaderingen tussen maart 2004 en november 2005. ${ }^{29}$ Ten slotte werd de geamendeerde tekst gestemd door de Senaat op I december 2005. Vervolgens vatte de commissie voor de Justitie van de Kamer van Volksvertegenwoordigers de bespreking van het ontwerp aan. In september 2006 werd evenwel besloten de behandeling van het ontwerp niet voort te zetten..$^{30}$

27 Parl. St. Kamer, 200I-2002, nr. 50-2043/oor en Senaat, 200I-2002, nr. 2-I288/I. Door de Federale Overheidsdienst Justitie en de commissies voor de Justitie van Kamer en Senaat werd op 3I januari 2003 een colloquium ingericht waarop de voorstellen van de commissie Strafprocesrecht werden toegelicht en bediscussieerd met vertegenwoordigers van de magistratuur en de advocatuur, evenals met parlementsleden zelf (voor de handelingen van dit colloquium: Parl. St. Kamer, 200I-02, nr. 50-2043/o02 en Senaat, 200I-02, nr. 2-I288/2).

28 Wetsvoorstel houdende het Wetboek van strafprocesrecht, ingediend door de heer H. Vandenberghe en anderen, Parl. St. Senaat, 2003-04, nr. 3-450/r.

29 Zie in dit verband het ruim II62 bladzijden tellende verslag van de commissie voor de Justitie van de Senaat (Parl. St. Senaat, 2005-06, nr. 3-450/20).

30 Parl. St. Kamer, 2006-07, nr. 5I-2138/004, 4. 
De tekst van het ontwerp van wetboek van strafprocesrecht, zoals deze aan de Senaat is voorgelegd en aldaar goedgekeurd, vertrok van een viervoudige bekommernis: het streven naar samenhang en coördinatie, het streven naar leesbaarheid en doorzichtigheid, het streven naar continuïteit en ten slotte het streven naar vernieuwing. Deze onderliggende bekommernissen waren ingegeven door de stand van het geldende strafprocesrecht. In de loop der jaren werden vele punctuele wijzigingen en toevoegingen aan het Wetboek van Strafvordering aangebracht. Daarnaast zijn vele zaken geregeld in complementaire wetten buiten het wetboek en ten slotte zijn vele zaken geregeld door de rechtspraak. Het geldende strafprocesrecht geeft aldus een vrij verwarde indruk en is in hoge mate pretoriaans.

\section{De achtergrond van de voorgenomen hervorming}

In de beleidsnota van de minister van Justitie die door deze laatste bij zijn aantreden in 2014 werd publiek gemaakt werd aangekondigd dat de regering op zijn voorstel "een keuze zal maken over het basisconcept en de fundamentele oriëntaties voor de toekomstige strafprocedure". ${ }^{3 \mathrm{I}}$ Hierbij dient er volgens de minister te worden gewaakt over het noodzakelijke evenwicht tussen de snelheid van de procedures en de rechten van verdediging.

Naast dit algemeen opzet van de hervorming werd ook nog de aandacht gevestigd op de doelstelling van een verkorting, vereenvoudiging en een meer efficiënt verloop van de strafprocedure, alsook het maximaal vermijden van verjaring en procedurefouten. Dit alles dient in de geest van de minister van Justitie de rode draad te vormen doorheen het hervormingsproject.

De ruimte ontbreekt om in te gaan op de methode die voor het project van hervorming van het strafprocesrecht wordt gebruikt. In tegenstelling tot de in Nederland gevolgde werkwijze blijkt dat de in België gekozen methode niet afwijkt van wat in het verleden werd aangewend. De in België beproefde methode is deze van de uitwerking van een voorstel door een wetenschappelijke commissie waarna door de regering bij het parlement een voorstel van tekst wordt ingediend.

In tegenstelling tot in Nederland is er zelden sprake van een voorafgaand traject van overleg waarbij breed advies wordt ingewonnen bij diverse instanties die de actoren van justitie vertegenwoordigen zoals het college van procureurs-generaal, de ordes van advocaten, de Hoge Raad voor de Justitie e.d.m. Meestal worden dergelijke instanties slechts in het besluitvormingsproces betrokken op het ogenblik dat de fundamentele keuzen reeds zijn gemaakt en het voorstel van tekst vervolgens voor advies aan deze instanties wordt overgemaakt in het licht van de komende parlementaire behandeling.

3I Beleidsverklaring Justitie, Parl. St. Kamer, 2014-I5, nr. 54-0020/oI8, p. I6. 
Een gerechtelijke organisatie kan niet alleen van buitenaf veranderd worden maar dient door endogene krachten het veranderingsproces door te voeren. ${ }^{2}$ Het is dan ook van het allergrootste belang dat ingrijpende wijzigingen aan het wettelijk instrumentarium tot stand komen in nauw overleg met diverse actoren van justitie, ook al mag bij dit alles niet uit het oog worden verloren dat een fundamentele hervorming van het strafprocesrecht in een democratische rechtsstaat uiteindelijk tot de verantwoordelijkheid van de wetgever behoort.

Of de maatschappelijke en politieke omstandigheden aanwezig zijn om ook in België een uitgebreid voorafgaand traject van overleg te organiseren kan worden betwijfeld. ${ }^{33}$ Wel dient te worden opgemerkt dat de huidige voorgenomen hervorming zoals hoger aangegeven deels steunt op de uitkomsten van een onderzoek dat door de voorganger van de huidige minister van Justitie werd opgezet en waarbij vertegenwoordigers van de actoren van justitie werden geconsulteerd. ${ }^{34}$

Veel meer dan de zonet genoemde eerder punctueel te noemen doelstellingen van een hervorming van het strafprocesrecht wordt een brede en fundamentele herziening van het Belgisch strafprocesrecht noodzakelijk gemaakt door de eenvoudige vaststelling dat er tot op heden nooit een grondige herziening is geweest. Uit het historisch overzicht blijkt immers dat de Belgische wetgever vanuit een soort pragmatisme maar wellicht ook vanuit de wens om een fundamentele herziening zo lang mogelijk uit te stellen er zich toe beperkt heeft de noodzakelijke aanpassingen aan de wetgeving aan te brengen om op die manier het systeem draaiende te houden. De realiteit bewijst dat dit ook tot op zekere hoogte gelukt is maar deze methode en aanpak hebben natuurlijk hun grenzen.

De voorheen genoemde viervoudige bekommernis die ten grondslag lag aan het in 2005 door de Senaat aangenomen wetboek van strafprocesrecht blijft ongetwijfeld actueel: het streven naar samenhang en coördinatie, het streven naar leesbaarheid en doorzichtigheid, het streven naar continuïteit en ten slotte het streven naar vernieuwing. Hierbij komt het feit dat de zeer snelle evolutie die het strafprocesrecht de laatste vijftien jaar heeft doorgemaakt een volledige herziening van het strafprocesrecht noodzakelijk maakt.

Zo zijn de opsporingsmethoden de laatste jaren aanzienlijk toegenomen. Niemand zal betwijfelen dat zulks gelet op de aard van de te bestrijden misdrijffenomenen noodzakelijk was maar de vraag rijst op welke manier het toezicht daarop dient te worden geregeld. Een aantal van deze methoden staat immers op gespannen voet met fundamentele rechten, zoals de bescherming van het privéleven.

32 R. Depre \& A. VAn Hondeghem, "Hervormingsvoorstellen voor justitie: verleden, heden en toekomst", Ius et actores, 20II, 25.

33 Zie hierover o.m. Ph. TRAEST, "Hervorming van het strafprocesrecht: een boeiende maar moeilijke onderneming", DD 20I6, 200-2II en in het bijzonder 207-209.

34 Ph. Traest, G. Vermeulen, W. De Bondt, T. Gombeer, S. RaAts \& L. van Puyenbroeck, Scenario's voor een nieuwe Belgische strafprocedure. Een praktijkgericht knelpuntenonderzoek, IRCP research series, vol. 49, Antwerpen, Maklu, 582 p. 
De gevolgen van vormfouten blijven een delicaat punt in het strafprocesrecht. De door het Hof van Cassatie met het arrest van I4 oktober 2003 in het leven geroepen Antigoonrechtspraak en de wettelijke consecratie hiervan in 2013 (zie later) ontslaan de wetgever er niet van om na vijftien jaar de vraag te stellen of deze oplossing al dan niet aan bijsturing toe is.

Bij dit alles komt nog de invloed van het supranationale niveau. Zowel de Europese Unie als het EVRM en de rechtspraak van het Europees Hof voor de Rechten van de Mens in Straatsburg hebben het nationale strafprocesrecht genoopt tot fundamentele aanpassingen en zullen dat de komende jaren blijven doen. De beleidsruimte waarover de nationale wetgever beschikt is hierbij nochtans niet onbestaande. Hij moet er onder meer voor zorgen dat deze instrumenten, die in beginsel geschreven zijn voor landen met een verschillende rechtstraditie en een verschillend systeem, op een coherente wijze worden ingepast in het nationale strafprocesrecht.

Dit alles dient te gebeuren met één uiteindelijk te bereiken doel voor ogen: de creatie van een strafprocesrechtelijk systeem dat toelaat het strafrecht op een efficiënte wijze toe te passen en tegelijk de individuele rechten van elkeen te waarborgen.

\section{De rolverdeling tussen het Openbaar Ministerie en de onderzoeksrechter}

\section{I Opsporingsonderzoek en gerechtelijk onderzoek}

De Belgische strafprocedure steunt van oudsher op het bestaan van twee afzonderlijke types van voorbereidend onderzoek, met name het gerechtelijk onderzoek en het opsporingsonderzoek. Het eerste vindt plaats onder de leiding en de verantwoordelijkheid van de onderzoeksrechter, het tweede onder de leiding van de procureur des Konings. In die zin kan dan ook worden gezegd dat het strafrechtelijk vooronderzoek een duale of tweeledige structuur kent.

Zonder in detail hierop in te gaan is het niet onbelangrijk voor ogen te houden dat deze tweeledige structuur het gevolg is van een historische evolutie waarbij in de loop der jaren werd afgestapt van de in het oorspronkelijke wetboek uit I8o8 aangenomen idee dat het vooronderzoek exclusief in handen lag van de onderzoeksrechter. In de geest van de opstellers van de oorspronkelijke Code d'instruction criminelle hadden de bevoegdheden van de procureur des Konings slechts een uitzonderingskarakter, met name in het geval van heterdaad. Dit verklaart ook waarom in het wetboek de opsporingsbevoegdheden van de diverse opsporingsinstanties niet exhaustief werden geregeld. De onderzoeksrechter had tot taak de waarheid aan het licht te brengen en mocht in deze optiek alles doen wat in zijn macht lag. Aangezien hij een rechter was, behoorde daar ook de bevoegdheid toe om fundamentele rechten van personen aan te tasten ten behoeve van het onderzoek. 
Voor de wet van 12 maart 1998, die het opsporingsonderzoek van een wettelijke basis voorzag (de zogenoemde kleine Franchimont-wet), was de procureur dan ook in beginsel overeenkomstig de artikelen 47 en 64 Sv. verplicht om, telkens als hij verder onderzoek wenselijk achtte, een onderzoeksrechter te vorderen. ${ }^{35}$ Het gerechtelijk onderzoek was in theorie aldus verplicht. Nochtans heeft reeds geruime tijd voor de wet van 12 maart 1998 het opsporingsonderzoek onder de leiding van de procureur des Konings zich in de praktijk ontwikkeld ${ }^{6}$ zodat slechts in een kleine minderheid van de gevallen een gerechtelijk onderzoek werd gevorderd. Thans zou nog nauwelijks in $5 \%$ van de gevallen een gerechtelijk onderzoek gevoerd worden, terwijl bovendien ook blijkt dat een meerderheid van de zaken die door de vonnisrechter worden behandeld het voorwerp hebben uitgemaakt van een opsporingsonderzoek, eerder dan van een gerechtelijk onderzoek onder leiding van de onderzoeksrechter.

Met de wet van 12 maart 1998 werd het bestaansrecht van het opsporingsonderzoek ook wettelijk erkend. Niet alleen werden de artikelen 47 en 64 Sv. in die zin aangepast dat de vordering van een gerechtelijk onderzoek voortaan facultatief was, ook werden bepalingen ingevoerd die een wettelijke basis verleenden aan het opsporingsonderzoek onder de leiding van het Openbaar Ministerie. Zo werd in artikel 28bis Sv. het opsporingsonderzoek omschreven als "het geheel van de handelingen die ertoe strekken de misdrijuen, hun daders en de bewijzen ervan op te sporen en de gegevens te verzamelen die dienstig zijn voor de uitoefening van de strafvordering" (art. 28bis S I, eerste lid Sv.). Tevens wordt bepaald dat het opsporingsonderzoek gevoerd wordt onder de leiding en het gezag van de bevoegde procureur des Konings. Hij draagt hiervoor ook de verantwoordelijkheid (art. 28bis § I, derde lid Sv.).

In hetzelfde artikel wordt uitdrukkelijk aangegeven dat behoudens de wettelijke uitzonderingen de opsporingshandelingen in het opsporingsonderzoek geen enkele dwangmaatregel mogen inhouden noch schending van individuele rechten en vrijheden (art. 28bis $\$ 3$ Sv.). Dwangmaatregelen zijn in het opsporingsonderzoek wel mogelijk bij de heterdaadprocedure of via mini-instructie. De wet vermeldt uitdrukkelijk dat inbeslagneming mogelijk is in een opsporingsonderzoek (derhalve ook buiten heterdaad).

Het uitgangspunt dat dwangmaatregelen die fundamentele rechten aantasten door een rechter moeten worden bevolen of ten minste door een rechter moeten gemachtigd worden, is logisch en behoeft weinig commentaar. Het is ook duidelijk dat dit uitgangspunt in elke hervorming van het strafprocesrecht zal worden behouden.

Artikel 28bis Sv. werd ten tijde van de goedkeuring van de wet van I2 maart 1998 als een van de krachtlijnen van de hervorming beschouwd. Deze bepaling werd immers voorgesteld "vanuit de bekommernis het opsporingsonderzoek uit het juridische vacuüm te halen waarin het zich nu al bijna tweehonderd jaar bevindt" en aldus een einde

35 R. Verstraeten, Handboek strafuordering, Antwerpen, Maklu, 2012, nr. 773.

36 Zie in dit verband L. CORNIL, "De la nécessité de rendre à l'instruction préparatoire en matière pénale le caractère légal qu'elle a perdu”, Rev. dr. pén., I93I, 809 e.v. 
te maken aan het pretoriaans karakter van dit type van vooronderzoek. ${ }^{37}$ Hierbij zij ook vermeld dat de proactieve recherche krachtens artikel 28 bis $§ 2$ Sv. onder het opsporingsonderzoek ressorteert, derwijze dat de procureur des Konings ook deze recherche leidt. Indien dwangmaatregelen moeten worden getroffen zal een gerechtelijk onderzoek onder de leiding van de onderzoeksrechter moeten worden gevorderd.

In 1998 werd in artikel 55 Sv. ook een definitie van het gerechtelijk onderzoek ingevoerd, die vrij gelijkaardig is aan deze van het opsporingsonderzoek, met dien verstande dat de uitsluiting van dwangmaatregelen niet in deze omschrijving is opgenomen. Volgens deze bepaling is het gerechtelijk onderzoek "het geheel van de handelingen die ertoe strekken de daders van misdrijuen op te sporen, de bewijzen te verzamelen en de maatregelen te nemen die de rechtscolleges in staat moeten stellen met kennis van zaken uitspraak te doen. Het wordt gevoerd onder de leiding en het gezag van de onderzoeksrechter". In de memorie van toelichting werd opgemerkt dat het ontwerp "door de instelling van de onderzoeksrechter te behouden, in plaats van de 'rechter van het onderzoek' niet alleen beoogt de prerogatieven van deze magistraat ongewijzigd te bewaren maar ze bovendien te verstevigen". ${ }^{8}$ Artikel 56 Sv. bepaalt dat de onderzoeksrechter de verantwoordelijkheid draagt voor het gerechtelijk onderzoek dat zowel à charge als à décharge wordt gevoerd. Hij beslist of het noodzakelijk is dwang te gebruiken of inbreuk te maken op de individuele rechten en vrijheden. In tegenstelling tot de procureur des Konings beschikt de onderzoeksrechter, gelet op de beperking van zijn bevoegdheden door zijn saisine, niet over een algemeen opsporingsrecht.

Het wetboek bevat aldus geen exhaustieve opsomming van de respectieve bevoegdheden van de procureur des Konings en de onderzoeksrechter. Wel is de rolverdeling tussen beiden vrij duidelijk als gevolg van het bestaan van de twee types van vooronderzoek enerzijds en de regeling van een aantal onderzoeksdaden in het wetboek waarbij wordt aangegeven tot wiens bevoegdheid zij behoren. In het bijzonder gaat het hier om de onderzoeksdaden die krachtens de wet uitdrukkelijk aan de onderzoeksrechter worden voorbehouden.

In het wetsontwerp van wetboek van strafprocesrecht dat in 2005 door de Senaat werd goedgekeurd - doch vervolgens in de Kamer niet werd aangenomen - werd wel geopteerd voor een afzonderlijke afdeling voor respectievelijk de handelingen van het opsporingsonderzoek en deze van het gerechtelijk onderzoek. ${ }^{39}$ Hoewel zulks sommige herhalingen veroorzaakt en het wetboek omvangrijker maakt, is deze werkwijze wel degelijk overzichtelijker. Dit neemt niet weg dat er op vandaag weinig of geen onduidelijkheid bestaat over de vraag welke onderzoekshandelin-

37 Wet van I2 maart 1998 tot verbetering van de strafrechtspleging in het stadium van het opsporingsonderzoek en het gerechtelijk onderzoek, Memorie van toelichting, Parl. St. Kamer, I99697, nr. 857/I, p. 2 I.

$3^{8}$ Wet van 12 maart 1998 tot verbetering van de strafrechtspleging in het stadium van het opsporingsonderzoek en het gerechtelijk onderzoek, Memorie van toelichting, Parl. St. Kamer, I99697, nr. 857/I, p. 39 .

39 Wetsvoorstel houdende het Wetboek van strafprocesrecht, ingediend door de heer H. Vandenberghe en anderen, Parl. St. Senaat, 2003-04, nr. 3-450/I. 
gen door de procureur des Konings kunnen worden gesteld en welke tot de exclusieve bevoegdheid van de onderzoeksrechter behoren.

Met de wet van 12 maart 1998 werd in artikel 28 septies Sv. de mini-instructie ingevoerd, waardoor niet alleen het onderscheid tussen het opsporingsonderzoek en het gerechtelijk onderzoek vervaagt maar ook het verband tussen dwangmaatregelen en het instituut van het gerechtelijk onderzoek deels wordt doorgeknipt. $4^{4}$ Het Openbaar Ministerie kan derhalve aan de onderzoeksrechter vragen bepaalde daden te stellen die onder zijn bevoegdheid vallen, zonder dat meteen een gerechtelijk onderzoek wordt ingesteld. Volgens de memorie van toelichting bij voormelde wet van 12 maart 1998 was het de bedoeling "enerzijds de onderzoeksrechter te ontlasten van kleinere relatief eenvoudige strafzaken zodat deze zich vooral kan wijden aan complexe zaken, anderzijds de met een gerechtelijk onderzoek gepaard gaande relatief zware procedure (regeling van de rechtspleging, beschikking van de raadkamer, hoger beroep bij de kamer van inbeschuldigingstelling,...) voor deze eenvoudige strafzaken te vermijden, zodat het Openbaar Ministerie desgevallend rechtstreeks kan daguaarden of seponeren". ${ }^{4}$

Deze rechtsfiguur werd zo opgevat dat deze geldt voor alle onderzoeksdaden die tot de exclusieve bevoegdheid van de onderzoeksrechter behoren, met uitzondering van enkele uiterst ingrijpende handelingen, die dan ook werden uitgesloten van de mini-instructie. Aanvankelijk werd de mini-instructie uitgesloten voor het bevel tot aanhouding, het huiszoekingsbevel en de bewakingsmaatregel bedoeld in artikel goter Sv. (de telefoontap). Later werd het verhoor van een volledig anonieme getuige (art. 86bis Sv.) aan deze uitzonderingen toegevoegd, evenals de observatie met gebruik van technische hulpmiddelen om zicht te verwerven in een woning (art. 56bis, tweede lid Sv.) en de inkijkoperatie (art. 89ter Sv.). ${ }^{42}$

Door de wettelijke regeling werd ook een evocatierecht voor de onderzoeksrechter ingevoerd. Hij kan immers beslissen of hij het dossier terugzendt naar de procureur des Konings dan wel of hij het gehele onderzoek voortzet, in welk geval een toestand van gerechtelijk onderzoek ontstaat. De wetgever was van oordeel dat door de vermelde uitsluitingen en dit evocatierecht voldoende garanties worden geboden om te vermijden dat het gerechtelijk onderzoek zou worden uitgehold of dat bepaalde fundamentele rechten in het gedrang zouden komen.

Recent werd door de wet van 5 februari 2016 (Potpourri II) de toepassing van de mini-instructie verruimd doordat de huiszoeking thans ook via mini-instructie kan worden gevraagd. Deze uitbreiding is aanzienlijk aangezien het huiszoekingsbevel een veel toegepaste onderzoekshandeling is en tot voor deze wijziging de

40 R. Verstraeten, o.c., nr. 734 .

$4 \mathrm{I}$ Wet van $\mathrm{I} 2$ maart 1998 tot verbetering van de strafrechtspleging in het stadium van het opsporingsonderzoek en het gerechtelijk onderzoek, memorie van toelichting, Parl. St. Kamer, I99697 , nr. 857/I, p. 37-38.

42 Wat deze laatste twee maatregelen betreft, was zulks niet de aanvankelijke bedoeling van de wetgever maar het Grondwettelijk Hof oordeelde dat, gelet op de vergelijking van deze maatregelen met de klassieke huiszoeking en telefoontap, de niet-uitsluiting van deze maatregelen van het toepassingsgebied van de mini-instructie een schending uitmaakte van de artikelen ${ }_{5}$ en 22 van de Grondwet (Arbitragehof, 2I december 2004, arrest 202/2004). 
noodzaak van een huiszoeking in vele gevallen de drijfveer was voor het Openbaar Ministerie om een gerechtelijk onderzoek van de onderzoeksrechter te vorderen. De regering had overigens aanvankelijk de bedoeling om nog verder te gaan en de mini-instructie ook mogelijk te maken bij telefoontap, observatie om zicht te verwerven in een woning en de inkijkoperatie in een woning. Alleen het bevel tot aanhouding en de volledig anonieme getuigenis zouden nog uitgesloten worden van de mini-instructie. Ingevolge de opmerkingen van de Raad van State ${ }^{43}$ werd dit opzet verlaten en werd uiteindelijk enkel de huiszoeking weggelaten uit de lijst van uitzonderingen op artikel 28septies Sv.

Ook werd bepaald dat in geval van een nieuwe vordering tot mini-instructie in hetzelfde dossier de zaak aanhangig gemaakt moet worden bij dezelfde onderzoeksrechter indien die nog in functie is. Eigenaardig genoeg werd niet bepaald dat een eventuele latere vordering tot gerechtelijk onderzoek ook tot dezelfde onderzoeksrechter moet worden gericht. ${ }^{44}$

Het evocatierecht van de onderzoeksrechter wordt door deze laatste op onaantastbare wijze uitgeoefend en de uitoefening van dit evocatierecht vereist niet dat de door het Openbaar Ministerie gevorderde onderzoekshandeling reeds werd uitgevoerd. ${ }^{45}$ De wet bepaalt evenmin criteria waaraan de onderzoeksrechter zijn beslissing kan toetsen doch er kan aangenomen worden dat het evocatierecht bedoeld is om de onderzoeksrechter te laten ingrijpen wanneer hij vaststelt dat de zaak te ernstig of te complex is om via een opsporingsonderzoek te worden afgedaan.

De onderzoeksrechter kan de door het Openbaar Ministerie gevraagde onderzoekshandeling ook weigeren. Tegen deze beslissing staat geen rechtsmiddel open. Indien het Openbaar Ministerie evenwel na deze weigering een gerechtelijk onderzoek vordert en vervolgens dezelfde onderzoekshandeling vordert, maakt de weigering door de onderzoeksrechter een strijdig bevel uit dat aanleiding kan geven tot een hoger beroep door het Openbaar Ministerie bij de kamer van inbeschuldigingstelling.

\subsection{Evaluatie}

Uit wat voorafgaat blijkt dat de taakverdeling tussen het Openbaar Ministerie en de onderzoeksrechter meer en meer verschuift in het voordeel van eerstgenoemde.

43 Advies van de Raad van State, Parl. St. Kamer, 2015-I6, nr. 54-I4I8/oor/92. In dit advies werd opgemerkt dat het inzagerecht voor de verdachte in het opsporingsonderzoek zoals geregeld in art. 2rbis Sv. minder waarborgen omvat zodat de vraag moet worden gesteld of de belangrijke verruiming van het toepassingsgebied van art. 28 septies Sv. niet moet leiden tot het toekennen van een inzagerecht in het dossier wanneer met toepassing van dat artikel door de onderzoeksrechter onderzoeksdaden worden verricht. J. MeEsE, "Potpourri II: een overzicht van de belangrijkste wijzigingen op vlak van strafprocesrecht", RW 2015-I6, I566.

45 Cass. 26 februari 2008, RW 2008-o9, 79I, met noot B. De Smet; Cass. 30 juni 2009, Arr. Cass. 2009, I869; Cass. I8 december 2012, Arr. Cass. 2012, 2886. 
Er zijn in de wet geen gevallen aangeduid waarin op basis van (de ernst of de aard van) het misdrijf op zich het voeren van een gerechtelijk onderzoek onder leiding van de onderzoeksrechter wordt voorgeschreven. De gevallen waarin verplichtend een gerechtelijk onderzoek moet worden gevoerd omwille van de beoogde onderzoeksdaden en het vooronderzoek derhalve geleid wordt door een rechter, zijn bovendien zeer beperkt geworden. Ook blijkt uit de opmerkingen van de Raad van State naar aanleiding van de aanvankelijk voorgenomen uitbreiding van de mini-instructie dat een versteviging en uitbreiding van het inzagerecht voor de verdachte in het kader van het opsporingsonderzoek de bezwaren tegen een nog verdere uitbreiding van de mini-instructie zou kunnen opheffen of op zijn minst afzwakken.

Dit alles noopt tot de vraag of de instelling van het gerechtelijk onderzoek nog dient te worden behouden.

Indien het antwoord op deze vraag bevestigend zou luiden is het alvast duidelijk dat er een onvoldoende draagvlak is om de huidige taakverdeling tussen Openbaar Ministerie en onderzoeksrechter opnieuw om te buigen in het voordeel van deze laatste instantie. In geval van een keuze voor het behoud van het gerechtelijk onderzoek zou het dus in werkelijkheid enkel gaan om een behoud van de bestaande taakverdeling.

Over de voor- en nadelen van één enkel type van vooronderzoek onder de leiding van het Openbaar Ministerie is al veel geschreven. De argumenten die in het debat over de onderzoeksrechter en het gerechtelijk onderzoek worden ontwikkeld zijn gekend.

De voorstanders van het huidige stelsel wijzen erop dat het onderzoek wordt geleid door een onpartijdige en onafhankelijke magistraat die het volledige onderzoek à charge en à décharge voert. De onderzoeksrechter biedt zodoende een garantie die het Openbaar Ministerie niet biedt, temeer nu de onderzoeksrechter sinds de wet van I2 maart 1998 niet langer officier van gerechtelijke politie is en er dus geen hiërarchische band meer is met het Openbaar Ministerie. Dergelijke garantie ontbreekt bij het Openbaar Ministerie, dat tevens vervolgende partij is. De waarheidsvinding is in deze redenering gebaat bij de leiding van het vooronderzoek door een onpartijdige rechter.

Bij het aanwenden van fundamentele rechten aantastende onderzoeksbevoegdheden betekent de onderzoeksrechter een bijkomende garantie van wettelijkheid en loyauteit. Zowel voor de inverdenkinggestelde als voor de burgerlijke partij en hun advocaten is hij bovendien een aanspreekpunt.

De afschaffing van de onderzoeksrechter en de invoering van een rechter van het onderzoek wordt daarentegen op diverse gronden bepleit. Vooreerst wordt gesteld dat de rechtspositie van de verdachte zou verbeteren omwille van een vorderings- 
recht dat hij zou hebben ten aanzien van deze rechter. ${ }^{46}$ Ook wordt aangevoerd dat de onderzoeksrechter in de praktijk thans systematisch zijn opdrachten delegeert aan de politie en op die manier eigenlijk zijn rol niet meer vervult. ${ }^{47}$ Ook zou de afschaffing van de onderzoeksrechter vanuit het oogpunt van management een voordeel zijn.

De voordelen van de afschaffing van de onderzoeksrechter werden door F. Schuermans opgesomd..$^{4}$ De meeste EU-landen kennen de onderzoeksrechter niet meer, beleidsafspraken tussen politie en parket kunnen niet meer doorkruist worden door een onderzoeksrechter en er zijn beheersmatige en budgettaire voordelen doordat de politiecapaciteit op een eenvormige manier aangewend kan worden. Ook wordt opgemerkt dat de figuur van de onderzoeksrechter in België dubbelzinnig is aangezien hij twee hoedanigheden cumuleert, met name deze van gedreven speurder enerzijds en onafhankelijk rechter anderzijds. Ten slotte wordt opgemerkt dat er geen reële mogelijkheden bestaan om een onderzoeksrechter ter verantwoording te roepen.

\subsection{Geïntegreerd vooronderzoek onder leiding van het Openbaar Ministerie}

Er zijn goede redenen om over te stappen naar dergelijk geïntegreerd vooronderzoek onder de leiding van het Openbaar Ministerie. ${ }^{49}$ De minister van Justitie heeft zich ook reeds uitgesproken in het voordeel van een dergelijke regeling..$^{\circ}$

Hierdoor wordt er niets gewijzigd aan de fundamentele regel dat een dwangmaatregel die fundamentele rechten aantast enkel kan worden uitgevoerd op grond van een bevel door een onafhankelijke rechter. Enkel zou dergelijk geïntegreerd vooronderzoek tot gevolg hebben dat deze rechter het onderzoek niet meer zou leiden. In deze zin zou dan ook kunnen worden gezegd dat een geïntegreerd vooronderzoek onder de leiding van het Openbaar Ministerie zou neerkomen op een

46 C. VAN DEN WyngaERT, Strafrecht en strafprocesrecht in hoofdlijnen, II, Antwerpen Maklu, 20I4, 639-640.

47 Zulks werd nog bevestigd in het verslag van de Hoge Raad voor de Justitie over het gerechtelijk onderzoek in de zaak Van Uytsel, waar gesteld wordt: "De meeste onderzoeksrechters hebben in de praktijk permanent tientallen-zelfs meer dan honderd - dossiers tegelijkertijd in behandeling. Het is dan ook niet realistisch er van uit te gaan dat een onderzoeksrechter in al die dossiers de leiding ten volle kan opnemen. Dit is materieel en menselijk onmogelijk." En "De ondersteuning van de politiediensten is dan ook cruciaal. Meer zelfs, er mag worden gesteld dat de echte leiding over het onderzoek, althans op het terrein, meestal in handen is van de teamchef of de dossierbeheerder bij de politie. De onderzoeksrechter is in hoge mate afhankelijk van wat het onderzoeksteam hem aanlevert en het is bijgevolg van groot belang voor het goede verloop van een onderzoek dat er een wederzijds vertrouwen is tussen onderzoeksrechter en onderzoeksteam." (Verslag van het bijzonder onderzoek naar de werking van de rechterlijke orde in de zaak van de moord op Annick Van Uytsel, goedgekeurd op 27 juni 20I2, www.hrj.be, p. II).

48 F. SCHUERmans, "Het vooronderzoek in strafzaken: één van die vele dringende werven van justitie" in Liber amicorum Alain De Nauw. Het strafrecht bedreven, F. DERUYCK \& M. ROZIE (eds.), Brugge, Die Keure, 20II, 787-808. Men raadplege tevens Y. LIEGoIs, "De onvermijdelijke evolutie van het strafprocesrecht" in De wet voorbij. Liber amicorum Luc Huybrechts, Antwerpen, Intersentia, 20I0, 22I-257.

49 Ph. Traest, G. Vermeulen, W. De Bondt, T. Gombeer, S. RaAts \& L. van Puyenbroeck, Scenario's voor een nieuwe Belgische strafprocedure. Een praktijkgericht knelpuntenonderzoek, IRCP research series, vol. 49, Antwerpen, Maklu, 90-94.

50 Algemene beleidsnota van de minister van Justitie d.d. 3 november 20I6, Parl. St. Kamer, 20I6I7, nr. 54-2III/O2I, I9-2O. 
veralgemening van de bestaande mini-instructie, doch zonder de bevoegdheid van evocatie door de betrokken rechter.

Een niet onaanzienlijk voordeel van dergelijk vooronderzoek is de efficiëntie van het vooronderzoek in die zin dat de doorlooptijd van een aantal onderzoeken zal verkorten als gevolg van het verdwijnen van het gerechtelijk onderzoek. Hierdoor komt immers de regeling van de rechtspleging te vervallen, evenals de soms lange tijd die in complexe dossiers verloopt tussen de beschikking tot mededeling en de eindvordering van het Openbaar Ministerie.

De doorlooptijd van het gerechtelijk onderzoek kan ook worden verbeterd door in te grijpen op de regeling van de rechtspleging zonder meteen het gerechtelijk onderzoek op te heffen..$^{\mathrm{I}}$ Nochtans rijst de vraag of in deze hypothese het gerechtelijk onderzoek niet in die mate ontdaan wordt van de aspecten die dit type van onderzoek een meerwaarde verlenen - zoals de beslissing over het verder verloop door een rechter - dat het dan ook weinig zinvol is dit type van vooronderzoek nog in stand te houden.

Ook zou een geïntegreerd vooronderzoek onder leiding van het Openbaar Ministerie zorgen voor meer eenheid in het vooronderzoek, wat ook de rechtszekerheid ten goede zal komen. Elke strafzaak zal op dezelfde manier worden behandeld: de leiding van het vooronderzoek berust steeds bij het Openbaar Ministerie met incidentele tussenkomst van een rechter van het onderzoek..$^{2}$ Zulks vergemakkelijkt natuurlijk de uitwerking van de rechten van de partijen tijdens dit vooronderzoek. De actuele verschillende regeling van de participatierechten van de partijen tijdens het opsporingsonderzoek en het gerechtelijk onderzoek staat op gespannen voet met het grondwettelijk gelijkheidsbeginsel ${ }^{53}$ en de creatie van één enkel type van vooronderzoek heeft het onmiskenbare voordeel om de uitwerking van deze rechten op een meer evenwichtige manier mogelijk te maken.

Ook zorgt één enkel type van vooronderzoek ervoor dat de richtlijnen van strafrechtelijk beleid van toepassing zullen zijn op alle vooronderzoeken.

Ten slotte zorgt dergelijk type van vooronderzoek ervoor dat de machtigende onderzoeksrechter meer afstand zal bewaren tot het vooronderzoek waarin van hem een beslissing wordt gevraagd. Wanneer een rechter enkel tussenkomt voor de machtiging van onderzoeksdaden en derhalve niet rechtstreeks betrokken is

5I T. DeCAIGNy, "Onderzoeksrechter of rechter van het onderzoek: elementen in het debat", RW 20I3-I4, 924.

52 J. MeEsE, "Sire, er zijn geen onderzoeksrechters meer: de toekomst van het gerechtelijk onderzoek: Frankrijk als inspiratiebron?” in F. Deruyck, M. De SwAEF, J. Rozie, M. Rozie, P. Traest \& R. Verstraeten (eds.), De wet voorbij. Liber amicorum Luc Huybrechts, Antwerpen, Intersentia, 20I0, 275 .

53 Wat het inzagerecht in het dossier betreft heeft het Grondwettelijk Hof in een arrest van 25 januari 2017 reeds geoordeeld dat art. 2 Ibis Sv. in strijd is met de art. Io en II van de Grondwet in zoverre in die bepaling niet voorzien is in een rechterlijke toetsing van de beslissing van de procureur des Konings terzake (of afwezigheid van beslissing) ( $\mathrm{GwH} 25$ januari 2017, NC 2017, 351-362, met noot S. RAATs: "Inzage in het strafdossier na het arrest van het Grondwettelijk Hof van 25 januari 20I7”). 
bij het vooronderzoek zou hij beter in staat kunnen zijn om alle argumenten en belangen tegen elkaar af te wegen alvorens te beslissen een bepaalde onderzoeksdaad te machtigen. ${ }^{54}$ De rechter zou meer rechter en minder onderzoeker worden, waar hij nu de beide hoedanigheden verenigt.

Aan de keuze voor een geïntegreerd vooronderzoek zijn ook nadelen en gevaren verbonden. Terecht wordt de aandacht gevestigd op het risico van de ontwikkeling van een tunnelvisie bij het Openbaar Ministerie, waar het onderzoek en de vervolging in dezelfde handen komen. Conceptueel kan niet worden geloochend dat zulks het gevaar vergroot dat het vooronderzoek zou gevoerd worden vanuit de optiek van een latere succesvolle strafvervolging en aldus minder aandacht geschonken zou worden aan een onderzoek van de elementen à décharge. Dit gevaar dient nochtans te worden gerelativeerd. Vooreerst is het ook nu al zo dat meer dan 95\% van alle vooronderzoeken wordt geleid door het Openbaar Ministerie, dat nadien ook eventueel tot vervolging overgaat. Het hoeft geen betoog dat deze situatie zich thans ook geregeld voordoet in zeer complexe zaken waar de elementen à charge en à décharge nauwkeurig moeten worden onderzocht. Bovendien mag ook niet uit het oog worden verloren dat het Openbaar Ministerie dat het vooronderzoek heeft geleid nadien voor de vonnisrechter ook verantwoording zal moeten afleggen over de wijze waarop dit onderzoek is gevoerd. Eventuele gebreken in het gevoerde vooronderzoek zullen tijdens de procedure voor de vonnisgerechten rechtstreeks aan het Openbaar Ministerie worden toegerekend. Dit perspectief zal het Openbaar Ministerie responsabiliseren bij de uitvoering van het vooronderzoek. Ten slotte mag niet vergeten worden dat de mogelijke tussenkomst van een rechter tijdens dit onderzoek (ambtshalve of op verzoek van de partijen) ook desgevallend kan zorgen voor een bijsturing waar zulks nodig zou zijn. Volledigheidshalve kan worden opgemerkt dat een tunnelvisie ook in een gerechtelijk onderzoek niet ondenkbaar is.

Er zal gewaakt moeten worden over de informatiepositie van de rechter die occasioneel tussenkomt in het vooronderzoek. Hij zal in staat moeten worden gesteld kennis te nemen van het dossier indien hij dit wenst. Het verzoek van de procureur des Konings tot machtiging van een bepaalde onderzoekshandeling zal gemotiveerd dienen te worden met vermelding van de relevante processtukken. Naar analogie met de bestaande regeling omtrent de mini-instructie verdient het aanbeveling het Openbaar Ministerie bij opeenvolgende verzoeken in eenzelfde dossier te verplichten zich te wenden tot dezelfde rechter. Bij weigering door de onderzoeksrechter van de gevraagde onderzoeksmaatregel kan het Openbaar Ministerie hoger beroep aantekenen bij de kamer van inbeschuldigingstelling.

Er bestaat geen onmiddellijke noodzaak tot herziening van de taakverdeling tussen Openbaar Ministerie en rechter wat specifieke onderzoeksdaden betreft. Uit een beperkte bevraging die werd uitgevoerd in het kader van het eerder aange-

54 T. Decaigny, "Onderzoeksrechter of rechter van het onderzoek: elementen in het debat", RW 20I3-I4, 930; R. VAN DE SOMPEL, "Woord en wederwoord: de onderzoeksrechter balancerend tussen argumenten en tegenargumenten”, Orde Dag 2004, 48. 
haalde onderzoek blijkt dat de actuele verdeling over het algemeen als bevredigend ervaren wordt.

In het huidige stelsel zijn er meerdere bevoegdheden die exclusief tot de beslissingsmacht van de onderzoeksrechter behoren. De procureur des Konings kan zelf dergelijke bevoegdheden niet uitoefenen. Wel bestaat bij de meerderheid van deze bevoegdheden de mogelijkheid om deze handelingen via een mini-instructie ten uitvoer te leggen in het kader van een opsporingsonderzoek.

Het gaat hierbij logischerwijze om bevoegdheden die fundamentele rechten aantasten zoals: de huiszoeking buiten een situatie van heterdaad (art. 87-88 Sv.), de inkijkoperatie zoals bedoeld in artikel 8gter Sv., de stelselmatige observatie om zicht te verwerven in een woning of in een lokaal aangewend voor beroepsdoeleinden of woonplaats van een advocaat of arts (art. 56bis, tweede lid Sv.), het openen van onderschepte post en het kennisnemen van de inhoud ervan (art. 88sexies Sv.), de uitbreiding van de zoeking in een informaticasysteem tot een ander informaticasysteem of delen ervan waartoe de personen die gerechtigd zijn het onderzochte informaticasysteem te gebruiken geen toegang hebben (art. 39bis $§ 4 \mathrm{~Sv}$.), het nemen van voorlopige maatregelen ten aanzien van rechtspersonen (art. 9I Sv.), het nemen van een DNA referentiestaal onder dwang van een verdachte of een persoon die een directe band heeft met het onderzoek (art. goundecies en goduodecies Sv.), het opsporen en lokaliseren van elektronische communicatie (art. 88bis Sv.), het onderscheppen, kennisnemen, doorzoeken en opnemen van niet voor publiek toegankelijke communicatie of gegevens van een informaticasysteem of een deel ervan (art. goter e.v. Sv). Er bestaat geen noodzaak en het is ook niet wenselijk om voor handelingen waarvoor thans een bevel van de onderzoeksrechter vereist is deze vereiste in de toekomst te laten vallen.

Hieraan kunnen nog toegevoegd worden: de volledig en gedeeltelijk anonieme getuigenis en het onderzoek aan het lichaam. Wat deze laatste onderzoeksdaden betreft, is de situatie evenwel enigszins anders. In een stelsel van een eengemaakt vooronderzoek zal de onderzoeksrechter enkel nog bevoegd zijn om te beslissen over de vraag van het Openbaar Ministerie om aan een bepaalde persoon het statuut van anonieme getuige toe te kennen. Daarna zal de procureur des Konings bevoegd zijn om de betrokken getuige te ondervragen. Wat het onderzoek aan het lichaam betreft rijst de vraag of het zinvol is thans nog in de wet te bepalen dat de onderzoeksrechter een onderzoek aan het lichaam onder dwang kan bevelen. De uitoefening van dwang ter gelegenheid van dergelijk onderzoek is immers niet vanzelfsprekend.

Bijkomend moet de vraag gesteld worden of sommige opsporingshandelingen die nu onder de exclusieve bevoegdheid van het Openbaar Ministerie vallen, niet geheel of gedeeltelijk aan de vereiste van een rechterlijke machtiging onderworpen zouden moeten worden.

Deze vraag rijst vooreerst met betrekking tot de toepassing van de bijzondere opsporingsmethoden. 
Onder de bijzondere opsporingsmethoden worden de observatie, de infiltratie en de informantenwerking verstaan. Artikel 47ter Sv. bepaalt uitdrukkelijk dat zij worden aangewend met als doel het vervolgen van daders van misdrijven, het opsporen, verzamelen, registreren en verwerken van gegevens en inlichtingen op grond van ernstige aanwijzingen van te plegen of reeds gepleegde strafbare feiten. De gerechtelijke finaliteit van deze methoden is dus duidelijk in de wet verankerd.

De wet bepaalt eveneens in artikel 47ter $\$ 2$ dat de procureur des Konings instaat voor de permanente controle over de toepassing van de bijzondere opsporingsmethoden door de politiediensten binnen zijn gerechtelijk arrondissement. Dit is ook het geval indien deze methoden worden aangewend in een gerechtelijk onderzoek. Tijdens een gerechtelijk onderzoek kan de onderzoeksrechter wel overgaan tot de machtiging van een observatie of een infiltratie. De wet (art. 47sexies Sv.) bepaalt wel dat de machtigingen waarin de onderzoeksrechter een bijzondere opsporingsmethode beveelt, ten uitvoer worden gelegd door de procureur des Konings. Dit laatste werd verantwoord geacht door de omstandigheid dat hij de enige is die aan de politieambtenaren machtiging kan geven om bepaalde misdrijven te plegen. De onderzoeksrechter behoudt wel de controle over het onderzoek in zijn geheel en de controle over de bijzondere methoden waarvoor hij de machtiging heeft verleend. Hieruit werd door het Grondwettelijk Hof afgeleid dat er geen schending is van de waarborg van een onafhankelijke en onpartijdige rechter. 55

Ook heeft de onderzoeksrechter in zijn gerechtelijk onderzoek steeds het recht om het vertrouwelijk dossier van de procureur des Konings aangaande de uitvoering van de bijzondere opsporingsmethoden in te zien. Om begrijpelijke redenen verhindert artikel 56 bis, vijfde lid Sv. dat hij van de inhoud ervan gewag zou maken in het kader van zijn gerechtelijk onderzoek.

Kenmerkend voor de bijzondere opsporingsmethoden is hun heimelijk karakter. Het feit dat het verslag van de toepassing van deze methoden niet in het gebruikelijke dossier terechtkomt maar wel in een vertrouwelijk dossier (dat op geen enkel ogenblik ter inzage komt van de beklaagde) bewijst het uiterst delicate karakter van deze methoden. Recent werd overigens nog een andere methode ingevoerd waarbij een vertrouwelijk dossier kan worden aangelegd. Het gaat met name om het onderhouden van contact op het internet, desgevallend onder een fictieve identiteit met één of meer personen waarvan er ernstige aanwijzingen zijn dat zij strafbare feiten die een correctionele hoofdgevangenisstraf van een jaar of een zwaardere straf tot gevolg kunnen hebben, plegen of zouden plegen (art. 46sexies Sv. $\left.{ }^{6}\right)$. Het gaat hierbij in werkelijkheid om een infiltratie op het internet.

De controle over de inhoud van dit vertrouwelijke dossier is opgedragen aan de Kamer van Inbeschuldigingstelling overeenkomstig artikel 235ter Sv.

55 Arbitragehof 2I december 2004, arrest nr. 202/400, overweging B 24.4.

56 Ingevoerd door art. 7 van de wet van 25 december 2016 (BS I7 januari 20I7). 
De verantwoording voor het feit dat de controle over de uitvoering van de bijzondere opsporingsmethoden ten allen tijde behoort tot de bevoegdheid van de procureur des Konings verhindert niet dat de constructie op dit punt enigszins eigenaardig overkomt. De systematiek van de onderzoeksdaden in het opsporingsonderzoek en het gerechtelijk onderzoek heeft in het algemeen tot gevolg dat de afbakening van de respectieve bevoegdheid van procureur des Konings en onderzoeksrechter in verband staat met de mate waarin bij de uitvoering van deze onderzoeksdaden fundamentele rechten worden aangetast. Indien zulks het geval is in een bepaalde mate dwingt deze systematiek tot een rechterlijke controle, desgevallend door de tussenkomst van een onderzoeksrechter in het raam van een gerechtelijk onderzoek of via een mini-instructie. Bij de bijzondere opsporingsmethoden daarentegen worden dezelfde maatregelen naargelang het geval door de procureur dan wel door de onderzoeksrechter gemachtigd, ook al tasten zij in dezelfde mate de privacy aan.

De oorspronkelijke aan de bevoegdheidsverdeling tussen Openbaar Ministerie en onderzoeksrechter ten grondslag liggende logica werd dan weer wel gevolgd in het geval van een observatie met technische hulpmiddelen om zicht te verwerven in een woning of een observatie in de woning of het kantoor van een advocaat of arts, waarbij steeds een machtiging van de onderzoeksrechter vereist is (art. 56bis, tweede lid Sv.).57

Indien het gerechtelijk onderzoek zou worden opgeheven en zou worden overgestapt naar een stelsel waarbij alle vooronderzoeken onder leiding van het Openbaar Ministerie zouden worden gevoerd rijst de vraag of de rechterlijke controle over deze bijzondere opsporingsmethoden niet zou moeten worden uitgebreid.

Er liggen goede argumenten voor om in een dergelijk geïntegreerd vooronderzoek onder leiding van het Openbaar Ministerie de bijzondere opsporingsmethoden van observatie en infiltratie aan de machtiging van een rechter te onderwerpen, ook in de gevallen waarin deze rechterlijke machtigingsvereiste nu nog niet opgelegd wordt. Het heimelijk karakter, dat zich onder meer vertaalt in de aanleg van een vertrouwelijk dossier, en de ingrijpende aard van deze methoden maakt dergelijke controle zinvol. Het stelselmatige karakter van de observatie impliceert dat deze methode zo ingrijpend is dat een rechterlijke machtiging hier zeker op zijn plaats is.

Wat de infiltratie betreft (art. 47 octies $§$ I, eerste lid) zijn er zeer goede redenen om deze methode aan een rechterlijke machtiging te onderwerpen. Een overstap naar een geïntegreerd vooronderzoek zonder enige wijziging van de bestaande regeling zou tot gevolg hebben dat de infiltratie in alle gevallen en zonder enige uitzondering tot de bevoegdheid van de procureur des Konings zou behoren. De

57 Bij de inkijkoperatie wordt dezelfde logica gevolgd aangezien de bevoegdheid van de procureur des Konings ter zake (art. 46quinquies Sv.) beperkt is tot een private plaats en een tussenkomst van de onderzoeksrechter vereist is wanneer de inkijkoperatie wordt uitgevoerd in een woning, of een lokaal aangewend voor beroepsdoeleinden of woonplaats van een advocaat of arts (art. 89ter Sv.). 
delicate aard van deze methode en aantasting van het privéleven die met de infiltratie gepaard gaat, rechtvaardigen het vereiste van een voorafgaande rechterlijke machtiging. Op het einde van de infiltratie zouden het strafdossier en het vertrouwelijk dossier dan ter controle aan de onderzoeksrechter moeten worden overgemaakt. Deze zou kunnen bevelen dat bepaalde stukken uit het vertrouwelijk dossier aan het proceduredossier moeten toegevoegd worden.

Wat de stelselmatige observatie betreft, rijst eveneens de vraag of deze niet aan een voorafgaande machtiging door de onderzoeksrechter onderworpen zou moeten worden. Het gaat hierbij om de observaties gedurende meer dan vijf opeenvolgende dagen of gedurende meer dan vijf niet opeenvolgende dagen binnen één maand, de observatie met behulp van technische middelen, een observatie met een internationaal karakter en een observatie die uitgevoerd wordt door de speciale eenheden van de federale politie. Op de in artikel 56 , tweede lid Sv. vermelde observatie na behoren deze alle tot de bevoegdheid van het Openbaar Ministerie. Het staat vast dat ook de andere observaties een aantasting van het privéleven met zich brengen. Om de werklast voor de onderzoeksrechters niet al te zeer op te drijven zou er aan gedacht kunnen worden om enkel de observaties van meer dan vijf dagen en de observaties met behulp van technische middelen aan een voorafgaande machtiging door de onderzoeksrechter te onderwerpen.

Dat de verdere uitvoering door het Openbaar Ministerie wordt beheerd is op zich geen bezwaar doch maakt een rechterlijke machtiging ook niet overbodig. Op zijn beurt wordt een controle over het vertrouwelijk dossier door de kamer van inbeschuldigingstelling zoals deze thans bestaat niet overbodig gemaakt door het feit dat een rechter de toepassing van deze bijzondere opsporingsmethode heeft gemachtigd.

Bij de zoeking in een informaticasysteem overeenkomstig artikel $39 \mathrm{bis} \mathrm{Sv}$. is het ook wenselijk om de bevoegdheid voor de procureur des Konings om te beslissen tot uitbreiding van de zoeking in een informaticasysteem tot een ander informaticasysteem of delen ervan waartoe de personen die gerechtigd zijn het onderzochte informaticasysteem te gebruiken toegang hebben (art. 39bis § $3 \mathrm{~Sv}$.), aan de machtiging van de onderzoeksrechter te onderwerpen. Het vereiste van toegang daartoe voor de persoon die gerechtigd is het onderzochte informaticasysteem te gebruiken lijkt logisch doch dit neemt niet weg dat het privéleven van andere personen dan de gebruiker van het onderzochte informaticasysteem wordt aangetast. Dit laatste element - de aantasting van het privéleven van andere personen - noopt tot de conclusie dat ook in het geval de gebruiker van het onderzochte informaticasysteem toegang heeft tot het andere systeem een rechterlijke machtiging gevraagd wordt. De uitbreiding van de zoeking in een informaticasysteem tot een ander systeem zou dan steeds een rechterlijke machtiging vereisen. Hiermee wordt overigens aangesloten bij de strekking van artikel 88ter Sv., zoals dit van toepassing was tot zijn opheffing door de wet van 25 december $2016.5^{8}$

58 Met betrekking tot de recente hervormingen met betrekking tot het digitaal bewijs en artikel 39bis Sv. in het bijzonder: C. CONINGS \& S. ROYER, "Verzamelen en vastleggen van digitaal bewijs in strafzaken", NC, 2017, 3II-338, en in het bijzonder 313-316. 
Gelet op deze opties zou de indeling van de handelingen van het onderzoek drieledig zijn: de handelingen die tot de exclusieve bevoegdheid van de procureur des Konings behoren, de onderzoekshandelingen waarvoor een voorafgaandelijke toelating van de onderzoeksrechter vereist is en de "gemengde" onderzoekshandelingen, met name degene die onder bepaalde omstandigheden en onder bepaalde voorwaarden een machtiging van de onderzoeksrechter vereisen. Tot de eerste categorie behoren aldus: de ondervraging en het verhoor (met inbegrip van het verhoor met behulp van audiovisuele middelen), de confrontaties, de plaatsopnemingen en wedersamenstellingen, het deskundigenonderzoek, de identificatie van elektronische communicatie, het inwinnen van gegevens over bankrekeningen en banktransacties, de snelle bewaring van informaticagegevens, de internetinfiltratie, de bewarende maatregelen, de uitgestelde tussenkomst, de informantenwerking. Tot de tweede categorie (steeds machtiging door de onderzoeksrechter vereist) zouden behoren: het opsporen en lokaliseren van elektronische communicatie, het onderscheppen, doorzoeken, kennisnemen en opnemen van niet voor publiek toegankelijke communicatie of gegevens van een informaticasysteem of een deel ervan, de anonieme getuigenissen, de infiltratie, de huiszoekingen en inbeslagnemingen, en de voorlopige maatregelen ten aanzien van rechtspersonen.

Tot de gemengde handelingen zouden dan behoren: het onderscheppen van post, de observatie, het onderzoek in een informaticasysteem en het DNA-onderzoek.

\section{Consequenties voor het vervolgingsbegrip}

De rolverdeling tussen het Openbaar Ministerie en de onderzoeksrechter kan gevolgen hebben voor het vervolgingsbegrip. Dit laatste begrip wordt in het actuele Wetboek van Strafvordering niet gedefinieerd. Nochtans vervult dit begrip een belangrijke rol aangezien dit begrip dienstig is of minstens kan zijn als aanknopingspunt voor rechtsbescherming in het vooronderzoek en bepaling van het tijdstip vanaf wanneer participatierechten aan partijen kunnen worden toegekend tijdens dat vooronderzoek.

Van oudsher wordt in het Belgische strafprocesrecht gewag gemaakt van het begrip 'strafvordering' als aanvangspunt van de vervolging. Deze term mist nochtans enige precisie en is vandaag de dag niet zeer bruikbaar meer. Algemeen wordt aangenomen dat een strafvordering tot doel heeft het sanctioneren van een inbreuk op de maatschappelijke orde en tot voorwerp de toepassing van een straf of maatregel.59 Aangenomen wordt ook dat de strafvordering wordt ingesteld wanneer deze aanhangig wordt gemaakt bij een rechter, onderzoeksrechter of rechter ten gronde, ongeacht wanneer dit gebeurt door het Openbaar Ministerie dan wel door de burgerlijke partij. De tussenkomst van een rechter bepaalt aldus in de klassieke visie het ontstaan en het bestaan van een strafvordering.

59 R. Verstraeten, Handboek Strafuordering, Antwerpen, Maklu, 20I2, 43, nr. I7. 
Anderzijds wordt het begrip van de strafvordering ook in vele gevallen gebruikt als synoniem voor het strafprocesrecht als dusdanig.

Het begrip "vervolging" wordt dan weer op een autonome wijze ingevuld. Het EHRM is op een consequente manier van oordeel dat er sprake is van een vervolging in de zin van artikel 6 EVRM van zodra een persoon weet dat hij zich moet verdedigen. In de Belgische context betekent dit dat een procedurefase die naar intern recht nog niet beschouwd wordt als een vervolging (bijv. omdat nog geen rechter in de zaak werd betrokken) in de context van het supranationale recht in bepaalde gevallen wel degelijk als een vervolging kan worden beschouwd.

De participatierechten van de partijen in het vooronderzoek worden thans door het Wetboek van Strafvordering geregeld zonder dat uitdrukkelijk een beroep wordt gedaan op het vervolgingsbegrip. In het gerechtelijk onderzoek is er weinig ruimte voor discussie aangezien in die fase aangenomen kan worden dat er steeds een vervolging is. De inverdenkinggestelde bevindt zich zonder enige twijfel in de fase van de vervolging en geniet op grond van de interne wet de in art. 6rter en 6rquinquies Sv. vermelde rechten.

In het opsporingsonderzoek werd in artikel 2Ibis Sv. een onvolledige regeling van inzage in het strafdossier uitgewerkt. ${ }^{60}$ De rechtstreeks belanghebbende kan aan het Openbaar Ministerie om inzage in het dossier verzoeken. Onder dit begrip vallen onder meer niet alleen de inverdenkinggestelde en degene tegen wie de strafvordering is ingesteld in het kader van het gerechtelijk onderzoek maar ook de verdachte in een opsporingsonderzoek. De wet bepaalt nochtans niet wie als een verdachte kan worden beschouwd.

Hieraan moet worden toegevoegd dat elkeen die ondervraagd wordt door de procureur des Konings of door een politiedienst in het kader van een opsporingsonderzoek kan vragen dat hij kosteloos een kopie van het proces-verbaal van zijn verhoor zou verkrijgen (art. 28quinquies $\$ 2$ Sv.).

Wie al dan niet verdachte is, dient derhalve op basis van de concrete gegevens van de zaak te worden bepaald. In het voorontwerp van wetboek van strafprocesrecht uit 2005 werd het begrip verdachte evenmin gedefinieerd doch werd aangegeven dat eenieder die over een zelfde feit verschillende malen gedurende het afgelopen jaar is ondervraagd door het parket of de politionele instanties door een verzoekschrift aan het Openbaar Ministerie kan vragen of hij ervan verdacht wordt een misdrijf te hebben gepleegd dat strafbaar is met een correctionele hoofdgevangenisstraf van een jaar of een zwaardere straf. Bij ontstentenis van antwoord binnen de twee maanden genoot de verzoeker van het inzagerecht zoals bepaald in het daaropvolgende artikel. ${ }^{6 r}$

6o Ingevoerd door art. 23 van de wet van 27 december 2012 houdende diverse bepalingen inzake justitie (BS 3 I januari 2013).

6I Wetsontwerp houdende het wetboek van strafprocesrecht, Parl. St. Kamer, 2005-06, nr. 2138/ooI, art. I23. 
De regeling van het recht op bijstand van de advocaat ${ }^{62}$ bij het politieverhoor heeft de bepaling van het aanvangspunt van een vervolging gemakkelijker gemaakt. Deze regeling heeft onder meer tot gevolg dat de voorwaarde van meerdere ondervragingen om als een verdachte te kunnen worden beschouwd in de huidige situatie geen zin meer heeft. Anderzijds zal bij een eventuele hervorming naar een geïntegreerd vooronderzoek onder de leiding van het Openbaar Ministerie de inverdenkingstelling van een verdachte niet meer als uitgangspunt voor het toekennen van participatierechten kunnen worden genomen. Met een dergelijke vorm van vooronderzoek wordt een nauwkeurige bepaling van het aanvangspunt van de vervolging in het interne recht van zeer groot belang. De hoger aangehaalde benadering van het EHRM dient hierbij als uitgangspunt maar dient te worden vertaald in een nationaalrechtelijk kader.

Dat een persoon verdachte wordt wanneer hij verplicht wordt om zich te verdedigen is logisch. Dit is in elk geval zo wanneer hij als verdachte wordt ondervraagd in de zin van artikel 47 bis $\$ 2$ Sv. Sedert de wijziging van deze bepaling door de wet van 2I november 2016 is het voor de persoon duidelijk of hij al dan niet als een verdachte wordt ondervraagd. Aangenomen kan worden dat hij vanaf dat ogenblik als een vervolgde persoon wordt beschouwd aangezien hij vanaf dat moment weet dat hij zich moet verdedigen. Deze bepaling lost nochtans niet alle problemen op aangezien er nog steeds situaties denkbaar zijn waarbij een persoon weliswaar nog niet als verdachte ondervraagd is in de zin van artikel $47 \mathrm{bis} \S 2$ Sv. maar toch geconfronteerd wordt met een bepaalde dwangmaatregel die impliceert dat er vermoedens rusten tegen zijn persoon, zijn woning of zijn goederen. Gedacht kan worden aan een huiszoeking en inbeslagneming, hoewel deze veelal zullen gepaard gaan met een ondervraging.

Het internrechtelijk begrip van de strafvordering is in dit opzicht niet meer dienstig. De betrokken persoon wordt immers door de ondervraging een verdachte, ook al is op dat ogenblik geen strafvordering aanhangig bij een rechter en is het heel goed mogelijk dat dit ook nooit zal gebeuren. Het onderzoek van het Openbaar Ministerie waarin een dergelijke ondervraging plaatsvond, kan immers perfect uitmonden in een seponering. Dit belet evenwel niet dat de betrokkene een verdachte is en zodoende participatierechten moet kunnen uitoefenen. Hierna zal nochtans blijken dat bij het uitoefenen van deze rechten het Openbaar Ministerie de bevoegdheid dient te bezitten om te oordelen - met eventueel een beroepsmogelijkheid bij de onderzoeksrechter - of de betrokken persoon wel degelijk de hoedanigheid heeft die wettelijk vereist wordt om dit participatierecht te kunnen uitoefenen.

62 Door de wetten van I3 augustus 20II (Wet tot wijziging van het Wetboek van strafvordering en van de wet van 20 juli I99o betreffende de voorlopige hechtenis, om aan elkeen die wordt verhoord en aan elkeen wiens vrijheid wordt benomen rechten te verlenen, waaronder het recht om een advocaat te raadplegen en door hem te worden bijgestaan (aangehaald als: wet Salduz), BS 5 september 20II) en van 2I november 2016 (Wet betreffende bepaalde rechten van personen die verhoord worden, BS 24 november 20r6). 
 \\ De rechten van partijen tijdens het vooronderzoek, in het bijzonder van de verdachte en het slachtoffer}

\section{I Het inzagerecht}

Aanvankelijk en tot 1998 waren er in het Belgische strafprocesrecht vrijwel geen participatierechten voor de privépartijen tijdens het vooronderzoek voorhanden. Zowel het gerechtelijk onderzoek onder de leiding van de onderzoeksrechter als het opsporingsonderzoek onder leiding van de procureur des Konings waren strikt eenzijdig. In de praktijk betekende zulks dat in beide types van vooronderzoek noch voor de verdachte noch voor het slachtoffer de mogelijkheid bestond om inzage in het dossier te verkrijgen noch om te verzoeken om het uitvoeren van bijkomende onderzoeksdaden.

Deze situatie werd als onwenselijk ervaren. Dit is niet verwonderlijk aangezien niet alleen de complexiteit van het vooronderzoek en de privacyaantastende aard van sommige onderzoeksverrichtingen maar ook de toegenomen mondigheid van de burger niet langer dulden dat gedurende lange tijd een onderzoek wordt gevoerd terwijl al die tijd de rechtstreeks belanghebbenden of betrokkenen van elk informatie verstoken blijven.

Bij de goedkeuring van de wet Franchimont van I2 maart 1998 werd nog veel begrip opgebracht voor het geheim van het vooronderzoek maar werd er ook op gewezen dat België in 1989 veroordeeld was door het EHRM met betrekking tot de inzage van het dossier door de verdachte die zich in voorlopige hechtenis bevindt. ${ }^{63}$

Geoordeeld werd dat er geen enkele reden bestaat voor een aparte behandeling van de gehechte verdachte en van de verdachte die in vrijheid is gelaten. Dit zou immers tot gevolg hebben dat in complexe zaken de verdediging meerdere jaren in volstrekte onwetendheid verkeert over de ontwikkeling van het onderzoek en het verzamelde bewijsmateriaal terwijl de gehechte verdachte al bij zijn eerste verschijning voor de raadkamer inzage krijgt in het dossier. ${ }^{64}$ Ook werd gewezen op het nauwe verband tussen het inzagerecht in het dossier en de mogelijkheid om bijkomende onderzoeksmaatregelen te vragen. Het recht op inzage van het dossier werd niet alleen aan de verdachte toegekend maar ook aan de burgerlijke partij, zijnde het slachtoffer dat zich reeds uitdrukkelijk als burgerlijke partij heeft aangesteld.

Dit stelsel werd met artikel 6rter Sv. enkel ingevoerd in het gerechtelijk onderzoek en houdt in dat de onderzoeksrechter nog steeds autonoom kon beslissen over de vraag of de gevraagde inzage ook wordt toegestaan. Het "inzagerecht" komt aldus in werkelijkheid neer op het recht om inzage in het dossier te vragen. Wel kan de beslissing van de onderzoeksrechter worden aangevochten door middel van een

63 EHRM 30 maart 1989, Publ. Cour, Serie A, vol. I5I (Lamy/België).

64 Wet van I2 maart I998 tot verbetering van de strafrechtspleging in het stadium van het opsporingsonderzoek en het gerechtelijk onderzoek, memorie van toelichting, Parl. St. Kamer, I99697, nr. 857/r, p. 46 . 
hoger beroep bij de kamer van inbeschuldigingstelling. Een automatisch inzagerecht is er dus niet doch daartegenover staat wel een rechterlijke toetsing van de weigering van het verzoek door de onderzoeksrechter. Wat de aangehouden verdachte betreft bleef een onderscheid bestaan, in die zin dat het inzagerecht van deze verdachte in het dossier ter gelegenheid van de controle van de voorlopige hechtenis door de raadkamer automatisch is zolang de hechtenis blijft bestaan. Zodra de verdachte in vrijheid wordt gesteld komt hij terecht in het systeem van een inzagerecht 'op verzoek'. ${ }^{65}$

Bij zijn beslissing over het gevraagde inzagerecht kan de onderzoeksrechter een beroep doen op diverse weigeringsgronden, die vrij breed zijn opgevat. Zelfs wanneer de verzoeker de vereiste hoedanigheid bezit, kan de onderzoeksrechter de inzage weigeren indien de noodwendigheden van het onderzoek dit vereisen of indien inzage een gevaar zou opleveren voor personen of een ernstige schending van hun privéleven zou inhouden of indien de verzoeker van geen rechtmatige beweegreden tot het raadplegen van het dossier doet blijken (art. 6iter § 3 Sv.). Zulks wordt logisch geacht omdat vermeden moet worden dat een inzage van het dossier het goede verloop van het onderzoek in gevaar zou brengen of de onderzoeksstrategie van de onderzoeksrechter zou doorkruisen. Aan het principieel geheim en inquisitoir karakter van het gerechtelijk vooronderzoek werd in 1998 niet geraakt doch dit karakter werd enkel afgezwakt.

In het opsporingsonderzoek - en derhalve in het merendeel van de strafrechtelijke vooronderzoeken - werd een dergelijk inzagerecht in I998 niet ingevoerd. Het resultaat was dat in dat opsporingsonderzoek het geheim karakter van het onderzoek absoluut bleef en de eventuele belanghebbenden geen inzagerecht konden laten gelden. Uiteraard bestond de mogelijkheid om aan de procureur des Konings een verzoek tot inzage te richten ${ }^{66}$ maar deze was niet verplicht daarop te antwoorden en een eventuele weigering kon bij geen enkele rechterlijke instantie worden bestreden. ${ }^{67}$ De enige andere uitzonderingen op het geheim karakter van het opsporingsonderzoek bestonden uit de overhandiging van een kopie van het verhoor (art. 28quinquies Sv.), de aanwezigheid van een vertrouwenspersoon bij het verhoor van een minderjarige ${ }^{68}$ en het recht om mededelingen te doen aan de pers (art. 28quinquies Sv.). De enorme discrepantie tussen het inzagerecht in het gerechtelijk onderzoek en de afwezigheid van een gelijkaardige regeling in het opsporingsonderzoek is des te frappanter nu via de met dezelfde wet van

65 Geoordeeld werd dat een systeem van periodieke inzage voor de niet aangehouden verdachte het gerechtelijk onderzoek al te zeer zou belasten. Een dergelijke periodieke inzage is wel gerechtvaardigd bij de voorlopige hechtenis waar er een beperking is van de persoonlijke vrijheid en kan niet per analogie worden toegepast op diegenen die zich niet in voorlopige hechtenis bevinden (Wet van 12 maart 1998 tot verbetering van de strafrechtspleging in het stadium van het opsporingsonderzoek en het gerechtelijk onderzoek, memorie van toelichting, Parl. St. Kamer, I996-97, nr. 857/I, p. 49).

66 Er bestond enkel een algemene bepaling die de procureur-generaal machtigde om inzage van een dossier te verlenen (art. 125 van het KB van 28 december 1950 op het Tarief in strafzaken).

67 De omstandigheid dat een weigering van inzage op grond van art. I25 van het Tarief in strafzaken niet het voorwerp kan uitmaken van een beroep bij een rechter werd overigens door het toenmalige Arbitragehof strijdig bevonden met de Grondwet (Arbitragehof I8 juli I997, arrest 54/97).

68 Ingevoerd met de wet van 13 april 1995 , thans art. 9Ibis Sv. 
I2 maart 1998 ingevoerde mini-instructie onderzoeksdaden waarvoor enkel de onderzoeksrechter bevoegd is, gesteld kunnen worden in de loop van het opsporingsonderzoek.

Deze discrepantie werd tot op zekere hoogte verminderd door de invoering met de wet van 27 december $2012^{69}$ van artikel 2 Ibis in het Wetboek van Strafvordering dat voorziet in de invoering van een inzagerecht in het opsporingsonderzoek. Een recht om inzage te vragen wordt toegekend aan elke 'rechtstreeks belanghebbende'. Over dit verzoek wordt geoordeeld door de onderzoeksrechter overeenkomstig artikel 6iter of door het Openbaar Ministerie naargelang de stand van de procedure. Het gevolg van deze bepaling is dubbel. Enerzijds wordt het inzagerecht in het gerechtelijk onderzoek uitgebreid van enkel de inverdenkinggestelde en de burgerlijke partij tot elke rechtstreeks belanghebbende. De beroepsmogelijkheden blijven bestaan voor al deze verzoekers.

Anderzijds wordt in het opsporingsonderzoek voor deze personen enkel het recht in het leven geroepen om aan het Openbaar Ministerie een verzoek te richten tot inzage in het strafdossier. Er wordt evenwel geen procedure ingevoerd en evenmin de mogelijkheid om de beslissing van het Openbaar Ministerie terzake aan te vechten voor een rechterlijke instantie. De bestaande discrepantie wordt zodoende in lichte mate versoepeld doch fundamenteel kan deze wijziging niet worden genoemd.

Dat deze bestaande discrepantie niet houdbaar is, bleek nog recent uit het arrest van het Grondwettelijk Hof van 25 januari 2017 (arrest 6/2017) ${ }^{70}$ waarbij voor recht gezegd werd dat artikel 2I bis Sv. de artikelen Io en II van de Grondwet schendt in zoverre het niet voorziet in een beroep bij een onafhankelijke en onpartijdige rechter tegen de weigering of de ontstentenis van een beslissing door het Openbaar Ministerie ten aanzien van een door een verdachte geformuleerd verzoek om toegang tot een dossier in het opsporingsonderzoek. Het Grondwettelijk Hof erkent in dit arrest de noodzaak van het geheim karakter van het vooronderzoek en aanvaardt dat zulks in het bijzonder verantwoord is door de zorg enerzijds een maximale efficiëntie te waarborgen bij het zoeken naar de waarheid en, anderzijds het vermoeden van onschuld te beschermen. Met betrekking tot het verschil in behandeling naargelang een beroep wordt gedaan op artikel 2I bis Sv. dan wel artikel 6r ter Sv. erkent het Grondwettelijk Hof dat het in het opsporingsonderzoek gerechtvaardigd is dat toegang tot het dossier door het Openbaar Ministerie wordt verleend of geweigerd. Niettemin oordeelt het Grondwettelijk Hof dat afbreuk wordt gedaan aan de vereisten van het recht op een daadwerkelijk rechtsmiddel en van de rechten van verdediging wanneer de weigering van het verzoek tot inzage of de ontstentenis van beslissing niet het voorwerp kan uitmaken van een controle door een onafhankelijke en onpartijdige rechter. De beslissing om al

$\overline{69}$ Wet van 27 december 2012 houdende diverse bepalingen inzake justitie (BS 3I januari 20I3). Art. 6I ter Sv. werd bij die gelegenheid herschreven en ook uitgebreid tot de rechtstreeks belanghebbenden in de zin van artikel $2 \mathrm{rbis} \mathrm{Sv}$.

70 Grondwettelijk Hof 25 januari 20I7, NC 2017, 351-362, met noot S. RAATs: "Inzage in het strafdossier na het arrest van het Grondwettelijk Hof van 25 januari 20I7”. 
dan niet inzage in het dossier te verlenen wordt immers genomen door het Openbaar Ministerie dat in voorkomend geval, in de verdere strafprocedure, de rol van vervolgende partij op zich zal nemen en dat dus niet als onpartijdig kan worden beschouwd (overweging B.5.2).

$\mathrm{Na}$ er op te hebben gewezen dat in een zeer groot aantal zaken het Openbaar Ministerie rechtstreeks dagvaardt voor de vonnisrechter zonder dat er een gerechtelijk onderzoek is geweest vervolgt het Grondwettelijk Hof: "Bovendien kan de procureur des Konings, krachtens artikel 28 septies van het Wetboek van Strafvordering dat het zogenaamde mini-onderzoek invoert, van de onderzoeksrechter vorderen een onderzoekshandeling te verrichten waarvoor alleen die rechter bevoegd is, zonder dat een gerechtelijk onderzoek wordt ingesteld. In dat geval kan een handeling worden verricht die afbreuk doet aan de grondrechten van de verdachte, zoals bijvoorbeeld het openen van een brief, het sluiten van een inrichting of een staalname onder dwang met het oog op een DNA-analyse, zodat het ontbreken van een beroep bij een onafhankelijke en onpartijdige rechter tegen de beslissing van het Openbaar Ministerie om toegang tot het dossier te weigeren of tegen diens stilzwijgen tot een onevenredige aantasting van de rechten van verdediging van de verdachte leidt" (overweging B.5.4).

Het Hof legt zodoende een verband tussen de ernst en het ingrijpend karakter van de onderzoeksdaden die bevolen kunnen worden in het opsporingsonderzoek en de noodzaak van een rechterlijke toetsing van een weigering van toegang tot het dossier. Met de uitbreiding van de mini-instructie en de bijhorende mogelijkheid om ook in het opsporingsonderzoek indringende onderzoeksdaden te stellen dringt zich logischerwijze ook in dit type van onderzoek een rechterlijke toetsing van het inzagerecht op.

De verwijzing door het Grondwettelijk Hof naar het niet onpartijdige karakter van het Openbaar Ministerie leidt niet tot een principiële onmogelijkheid van de aanwending van deze onderzoekshandelingen in het opsporingsonderzoek (via een mini-instructie) maar dwingt wel tot een rechterlijke toetsing van de beslissing van het Openbaar Ministerie inzake een verzoek tot inzage door een onafhankelijke rechter. Nergens geeft het Grondwettelijk Hof te kennen dat het recht van verdediging vereist dat deze rechter ook zelf het onderzoek zou moeten leiden.

Het Grondwettelijk Hof houdt rekening met de onmiskenbare vaststelling dat sedert de wijziging van artikel 28septies van het Wetboek van Strafvordering door de Potpourri II-wet van 5 februari 2016 de mogelijkheid van mini-instructie enkel wordt uitgesloten bij het bevel tot aanhouding bedoeld in artikel I6 van de Voorlopige Hechteniswet, de volledig anonieme getuigenis zoals bedoeld in artikel 86bis Sv., de telefoontap bedoeld in artikel goter Sv. en de onderzoekshandelingen als bedoeld in de artikelen 56bis, tweede lid en 8gter Sv. (respectievelijk de observatie met technische middelen om zicht te verwerven in een woning en de inkijkoperatie). 


\subsection{Het inzagerecht in een geïntegreerd vooronderzoek}

De discrepantie tussen de regelingen in de beide vormen van strafrechtelijk vooronderzoek zoals deze is gesanctioneerd door het Grondwettelijk Hof dwingt aldus ongetwijfeld tot een hervorming.

Voorheen heeft de Commissie Strafprocesrecht in 2005 vanuit de optiek van het behoud van de figuur van de onderzoeksrechter voorgesteld om de kloof tussen de beide types van vooronderzoek te dichten door ook in het opsporingsonderzoek gelijkaardige rechten in het leven te roepen ${ }^{71}$ doch deze voorstellen werden niet goedgekeurd in de Kamer van volksvertegenwoordigers. Toen werd de creatie van deze bijkomende rechten niet steeds gunstig onthaald waarbij de vraag werd gesteld of het principe van het geheim van het vooronderzoek er niet de oorzaak van is dat de invulling van effectieve rechten enkel mogelijk is door de creatie van tussentijdse procedures. ${ }^{72}$

De invoering van een dergelijk inzagerecht in het dossier in het stelsel van een eengemaakt geïntegreerd vooronderzoek onder de leiding van het Openbaar Ministerie vereist een antwoord op de vraag hoe ruim de kring van personen dient te zijn die van een dergelijk inzagerecht gebruik kan maken. In dit opzicht valt de uiterst ruime omschrijving van de term "rechtstreeks belanghebbende" in artikel 2rbis en 6iter Sv. op. Het gaat met name om: de inverdenkinggestelde, degene tegen wie de strafvordering is ingesteld in het kader van een gerechtelijk onderzoek, de verdachte, de burgerlijke partij, degene die een verklaring van benadeelde persoon heeft afgelegd, evenals degenen die in hun rechten zijn getreden of die hen als lasthebber ad hoc, curator, voorlopig bewindvoerder, voogd of voogd ad hoc vertegenwoordigen (art. 2rbis, tweede lid Sv.). In andere gevallen wordt de beslissing genomen door het Openbaar Ministerie (art. 2Ibis, derde lid Sv.).73

Dergelijk uitgebreid inzagerecht voor een grote groep van personen is zeker werkbaar in een stelsel waarbij er geen dwingende procedure is ingesteld voor de behandeling van deze vraag noch enige toetsingsbevoegdheid van de beslissing bij een rechter, zoals het geval is in het opsporingsonderzoek.

In een stelsel van één enkel soort vooronderzoek is het logisch dat een vraag tot inzage wordt ingediend bij de instantie die het vooronderzoek leidt, met name het Openbaar Ministerie. Ook uit de rechtspraak van het Grondwettelijk Hof volgt dat er geen enkel bezwaar bestaat tegen het toekennen van een dergelijke

7I Wetsontwerp houdende het Wetboek van Strafprocesrecht, Parl. St. Senaat 2005-06, nr. 3-450/I2, in het bijzonder de voorgestelde artikelen 123 tot 125 . Aan de verdachte en aan de benadeelde persoon werd het recht verleend om inzage in het dossier te vragen en de uitvoering van bijkomende onderzoekshandelingen. Weliswaar werd ook in deze voorstellen bepaald dat tegen de beslissing van het Openbaar Ministerie geen rechtsmiddel openstaat maar de betrokkene kon na een wachttermijn van drie maanden na de vorige beslissing een nieuw verzoekschrift indienen.

72 Y. Liegois, "De onvermijdelijke evolutie van het strafprocesrecht" in De wet voorbij. Liber amicorum Luc Huybrechts, Antwerpen, Intersentia, 20I0, 225.

73 Hiermee wordt aansluiting gezocht bij het stelsel van artikel I25 van het KB van 28 december I950 houdende het Tarief in strafzaken. 
bevoegdheid aan het Openbaar Ministerie. Het toekennen van een beroepsmogelijkheid tegen deze beslissing van het Openbaar Ministerie bij een rechter, in casu de onderzoeksrechter, lijkt noodzakelijk. Zeer theoretisch beschouwd zou de bestaande ongelijkheid tussen het gerechtelijk onderzoek en het opsporingsonderzoek ook komen te verdwijnen wanneer in een dergelijk eengemaakt stelsel in geen geval een hoger beroep tegen de beslissing van het Openbaar Ministerie mogelijk zou worden gemaakt. Nochtans blijkt uit het eerder aangehaalde arrest van het Grondwettelijk Hof van 25 januari 2017 dat een hoger beroep zeker wenselijk is, gelet op de indringende onderzoeksmaatregelen die zullen kunnen worden bevolen en uitgevoerd.

De veralgemening van het inzagerecht met een appelrecht zou dan ook desgewenst kunnen rechtvaardigen dat de kring van personen die zich op dit recht kunnen beroepen enigszins wordt beperkt. ${ }^{74}$ Overigens verhindert zulks niet dat de personen die niet tot deze gerechtigden behoren zoals nu het geval is een aanvraag kunnen richten tot het Openbaar Ministerie, zij het dan zonder verder uitgewerkte procedure, noch een recht van hoger beroep. Anderzijds is het wenselijk dat de toestand van de burger er met de hervorming niet op achteruitgaat en dat de personen die vandaag op grond van artikel 2rbis Sv. in aanmerking komen om inzage te vragen dat ook in de vernieuwde procedure zouden kunnen doen.

Ook zouden de lichtste misdrijven van deze regeling kunnen worden uitgesloten, bijvoorbeeld de misdrijven die enkel met een geldboete kunnen worden beteugeld.

Er zou dan ook geopteerd kunnen worden voor het toekennen van een automatisch inzagerecht aan de verdachte en de persoon die een verklaring van benadeelde persoon heeft gedaan na een termijn van zes maanden vanaf de opstelling van het eerste proces-verbaal. Zoals hoger aangegeven kan als een verdachte worden beschouwd de persoon die in die hoedanigheid is ondervraagd alsmede de verdachte die verplicht is zich te verdedigen, wanneer een bepaalde dwangmaatregel die impliceert dat er vermoedens op hem rusten is genomen tegen zijn persoon, zijn woning of goederen. Vanzelfsprekend kan inzage worden geweigerd omdat men de vereiste hoedanigheid niet heeft.

Indien het parket het geheim karakter van het onderzoek zou wensen te verlengen voor een langere periode dan zes maanden zou hiertoe een verzoek kunnen worden ingediend bij de onderzoeksrechter.

De bestaande weigeringsgronden die thans in artikel 6rter Sv. worden aangegeven zijn accuraat en voldoende ruim omschreven. Zo kan de inzage geweigerd worden wanneer de noodwendigheden van het onderzoek dit vereisen, indien de inzage een gevaar zou opleveren voor personen of een ernstige schending van hun privéleven zou inhouden of indien de verzoeker van geen rechtmatige beweegredenen tot het raadplegen van het dossier doet blijken. Nu het huidige artikel

74 Zie in dit verband ook S. RAATs, "Inzage in het strafdossier na het arrest van het Grondwettelijk Hof van 25 januari 2017”, NC 2017, 362-363. 
2Ibis Sv. geen weigeringsgronden vermeldt of aanreikt dienen de in artikel 6rter Sv. bestaande weigeringsgronden in een geïntegreerd vooronderzoek te worden veralgemeend. Ook zou aan het Openbaar Ministerie het recht kunnen worden verleend om inzage te weigeren indien het dossier enkel de verklaring of aangifte bevat waarvan de verzoeker reeds een afschrift heeft ontvangen.

De vermelde toekenning van een 'automatisch' inzagerecht na een periode van zes maanden (vanaf het eerste proces-verbaal) komt er dan ook op neer dat in deze eerste periode (eventueel verlengd door de onderzoeksrechter) alle weigeringsgronden zouden kunnen worden aangewend terwijl na deze termijn een weigering van inzage enkel verantwoord zou kunnen worden door de omstandigheid dat de verzoeker niet een van de in de wet vermelde hoedanigheden bezit.

Om de werklast binnen de perken te houden en de voortgang van het onderzoek niet te hinderen zou ook kunnen bepaald worden dat een verzoekschrift tot inzage pas zou kunnen ingediend worden ten vroegste één maand na de opstelling van het eerste proces-verbaal.

\subsection{Bijkomende onderzoekshandelingen}

Het recht om bijkomende onderzoekshandelingen te vorderen gedurende het strafrechtelijk vooronderzoek is een participatierecht dat vanuit zijn aard nauw aansluit bij het inzagerecht. De uitoefening van het inzagerecht kan er immers toe leiden dat de verdachte of de benadeelde persoon van oordeel zijn dat bijkomende onderzoeksdaden zich opdringen. Het inzagerecht is in die zin dan ook van essentieel belang om op een effectieve manier dit participatierecht in verband met eventuele bijkomende onderzoeksdaden uit te oefenen.

Met de reeds vermelde wet van 12 maart 1998 werd het recht om bijkomend onderzoek te vorderen enkel ingevoerd in de fase van het gerechtelijk onderzoek. Dit recht, dat werd ingebed in artikel 6rquinquies Sv., gaat verder dan de toen bestaande praktijk waarbij op een louter pretoriaanse wijze aan de onderzoeksrechter bijkomende onderzoeksdaden werden gevraagd doch waarbij geen enkele formele procedure was vastgelegd en derhalve ook geen recht van hoger beroep tegen de beslissing van de onderzoeksrechter.

Er werd toen ook op gewezen dat dit recht verder gaat dan de loutere uitoefening van een recht van verdediging maar ook het belang van het onderzoek zelf dient. Het dossier dat tijdens het gerechtelijk onderzoek wordt samengesteld heeft immers een zeer belangrijke impact op het verloop van de rechtspleging in zijn geheel. De omstandigheid dat het onderzoek ter terechtzitting van het vonnisgerecht in vele gevallen niet neerkomt op een tegensprekelijk overdoen van het onderzoek doch in werkelijkheid neerkomt op een tegensprekelijk debat over en op basis van de tijdens het vooronderzoek vergaarde en op papier gestelde gegevens versterkt het belang van dat vooronderzoek en de mogelijkheid om de rechts- 
pleging ten gronde te beïnvloeden. De noodzaak om het dossier op een meer evenwichtige manier samen te stellen is dan ook cruciaal..$^{75}$

De uitwerking van deze regeling is analoog aan deze van het inzagerecht. Dit recht staat open voor de inverdenkinggestelde en de burgerlijke partij en de weigeringsgronden zijn eveneens ruim. De onderzoeksrechter kan het verzoek afwijzen indien hij de maatregel niet noodzakelijk acht om de waarheid aan de dag te brengen of indien hij deze maatregel op dat ogenblik nadelig acht voor het onderzoek (art. 6rquinquies $\$ 3$ Sv.). Bij gebrek aan een beslissing binnen de opgelegde termijn van één maand (of acht dagen) vermeerderd met vijftien dagen of in geval van weigering kan de verzoeker zich tot de kamer van inbeschuldigingstelling wenden.

In tegenstelling tot het in artikel 6rter Sv. ingebouwde inzagerecht dat recent uitgebreid werd - weliswaar in een afgezwakte vorm - tot het opsporingsonderzoek (art. 2I bis Sv.) is zulks niet gebeurd met het recht om bijkomende onderzoeksdaden te vorderen. Deze regeling is tot op vandaag beperkt gebleven tot het gerechtelijk onderzoek, hoewel een verdachte en benadeelde persoon in de loop van een opsporingsonderzoek ook zonder wettelijke bepaling het recht hebben om de procureur des Konings te verzoeken een naar hun oordeel noodzakelijke onderzoekshandeling te stellen. Bij weigering of gebrek aan antwoord staat hier evenwel geen rechtsmiddel open. Het is dan ook logisch en te verwachten dat de ongelijkheid tussen de beide types van vooronderzoek die door het Grondwettelijk Hof met betrekking tot het inzagerecht werd vastgesteld bij het eerder vermelde arrest van 25 januari $2017^{76}$ mutatis mutandis ook opgaat voor de regeling van het verzoek om bijkomende onderzoekshandelingen. Het belang van een rechterlijke toetsing van de beslissing van het Openbaar Ministerie met betrekking tot het inzagerecht geldt in dezelfde mate voor de toetsing van de beslissing van het Openbaar Ministerie inzake gevraagde bijkomende onderzoeksdaden. Het nauwe verband tussen beide participatierechten noopt tot deze conclusie. Een inzagerecht is immers noodzakelijk voor de uitoefening van het recht om bijkomende onderzoeksdaden te vragen; een inzagerecht zonder de effectieve mogelijkheid om bijkomende onderzoeksdaden te vragen is daarentegen vrij inhoudsloos.

\subsection{Bijkomende onderzoekshandelingen in een geïntegreerd vooronderzoek}

In een stelsel van een geïntegreerd vooronderzoek onder leiding van het Openbaar Ministerie dient derhalve aan de benadeelde en de verdachte - op dezelfde manier afgelijnd als bij de uitoefening van het inzagerecht - het recht te worden verleend om aan het Openbaar Ministerie aanvullende onderzoekshandelingen te vragen. Bij weigering dient een rechterlijke toetsing van de beslissing mogelijk te zijn door middel van een hoger beroep bij de onderzoeksrechter. Zoals ook nu het geval is, kan een wachttermijn van minstens drie maanden worden ingevoerd

75 Wet van I2 maart 1998 tot verbetering van de strafrechtspleging in het stadium van het opsporingsonderzoek en het gerechtelijk onderzoek, memorie van toelichting, Parl. St. Kamer, I99697, nr. 857/I, 52.

76 Zie noot 70 . 
vooraleer een nieuw verzoek tot het stellen van bijkomende onderzoekshandelingen kan worden ingediend.

Er bestaan geen redenen om het recht op bijkomende onderzoekshandelingen te vragen op een beperktere manier in te vullen wat het slachtoffer betreft. Het belang van een evenwichtig vooronderzoek geldt in dezelfde mate voor het slachtoffer als voor de verdachte. Ook voor het slachtoffer kan het vooronderzoek decisief zijn, gelet op de invloed ervan op het procedureverloop voor het vonnisgerecht. Indien een gebrek in het vooronderzoek leidt tot het afwijzen van de vordering door het vonnisgerecht beschikt het slachtoffer immers niet over een bijkomende kans om zijn vordering voor een andere rechter (bijv. de burgerlijke rechter) te stellen. Het gezag van het strafrechtelijk gewijsde verzet zich hiertegen.

De toelating van het slachtoffer tot het strafproces impliceert dan ook dat hij als volwaardige procespartij ook moet kunnen genieten van de participatierechten die aan de verdachte ter beschikking zijn gesteld, in de mate dat deze van belang zijn voor zijn burgerlijke vordering. Het EHRM heeft erkend dat een persoon die een verdedigbare klacht aanvoert met betrekking tot een aantasting van zijn fysieke of psychische integriteit recht heeft op een efficiënt gevoerd vooronderzoek, ook al gaat het hier niet om een resultaatsverbintenis maar een middelenverbintenis. Het slachtoffer dient in dit onderzoek ook te kunnen participeren.77 Er bestaat evenwel geen noodzaak om een dergelijk recht om bijkomende onderzoekshandelingen te verzoeken ook toe te kennen aan andere belanghebbenden zoals de burgerlijk aansprakelijke partij of de vrijwillig tussenkomende partij.

De Slachtofferrichtlijn 20I2/29/EU van 25 oktober 2012 verplicht strikt genomen de nationale lidstaten niet om een dergelijk uitgebreid inzagerecht en recht om bijkomende onderzoekshandelingen te vorderen aan het slachtoffer te verlenen. Anderzijds dient wel voor ogen te worden gehouden dat de Richtlijn de rol van het slachtoffer onder meer afhankelijk stelt van het nationale rechtstelsel en onder meer van de vraag of volgens het nationale stelsel het slachtoffer juridisch partij is in de strafprocedure. ${ }^{8}$ Artikel $6.2 \mathrm{~b}$ van de Richtlijn vermeldt uitdrukkelijk de informatie waardoor het slachtoffer de stand kan kennen van de strafprocedure en verwijst hierbij opnieuw naar het nationale rechtsstelsel. Het gegeven dat het slachtoffer zich in de actuele regeling tijdens het gerechtelijk onderzoek burgerlijke partij kan stellen pleit ervoor om ook in een geïntegreerd vooronderzoek uitgebreide participatierechten toe te kennen. Hierdoor wordt ook de kwaliteit van het vooronderzoek vanuit het oogpunt van het slachtoffer verbeterd.

77 EHRM 2 mei 20I7, B.V./België, § 55-67. In deze zaak werd geoordeeld dat de passiviteit van de bevoegde autoriteiten, de vertraging in het onderzoek en het gebrek aan coördinatie een schending uitmaakten van art. 3 EVRM. De feiten die door het slachtoffer werden aangebracht werden ook beschouwd als een schending van art. 3 EVRM. Uit deze uitspraak volgt ook dat het slachtoffer op de hoogte dient te worden gebracht van een beslissing tot buitenvervolgingstelling.

78 Richtlijn 20I2/29/EU van het Europees Parlement en de Raad van 25 oktober 2012 tot vaststelling van minimumnormen voor de rechten, de ondersteuning en de bescherming van slachtoffers van strafbare feiten, en ter vervanging van Kaderbesluit 200I/220/JBZ, Pb.L. I4 november 20I2, afl. 3I5, 57, overweging 20. 
Het Wetboek van Strafvordering bevat eveneens een procedure waarbij eenieder die geschaad wordt door een opsporingshandeling met betrekking tot zijn goederen de opheffing ervan kan vragen aan de procureur des Konings of aan de onderzoeksrechter, naargelang het gaat om een opsporingsonderzoek dan wel om een gerechtelijk onderzoek. ${ }^{79}$ Een dergelijke procedure is zinvol gelet op de toename van de mogelijkheden waarbij beslag gelegd kan worden op goederen en waarbij andere maatregelen kunnen worden genomen waarvan de nadelige gevolgen ook andere personen kunnen treffen dan de verdachten. Ook de verruiming van de mogelijkheden tot verbeurdverklaring heeft geleid tot meer beslagmogelijkheden en ook meer beslagen. ${ }^{80}$ De huidige in artikel 28 sexies Sv. vervatte regeling kan zonder veel problemen worden overgenomen, zij het dat de rechterlijke toetsing niet meer dient te worden uitgevoerd door de kamer van inbeschuldigingstelling zoals nu het geval is maar door de onderzoeksrechter. De thans voorziene wachttermijn van drie maanden kan ook in een stelsel van geïntegreerd vooronderzoek worden overgenomen.

\section{De positie van het slachtoffer bij het uitlokken of laten voortduren van een strafrechtelijk vooronderzoek}

Het vraagstuk van de rechten van de partijen rijst natuurlijk ook bij het einde van het vooronderzoek.

Een voorvraag hierbij is die naar de positie van het slachtoffer bij de sturing van het onderzoek. Het slachtoffer kan weliswaar inzage verkrijgen in het dossier en bijkomende onderzoekshandelingen vorderen. Dit impliceert evenwel dat er een vooronderzoek werd opgestart en garandeert anderzijds niet dat er ook een proces voor de rechter komt. In de huidige stand van het Belgisch strafprocesrecht bezit het slachtoffer een uitermate sterke rechtspositie omdat het de opstart van een vooronderzoek kan afdwingen door middel van een klacht met burgerlijke partijstelling. $\mathrm{Nu}$ dit instrument logischerwijze onlosmakelijk verbonden is met het instituut van het gerechtelijk onderzoek onder leiding van een onderzoeksrechter heeft de keuze voor een geïntegreerd vooronderzoek onder leiding van het Openbaar Ministerie vanzelfsprekend gevolgen voor de positie van het slachtoffer. Deze keuze impliceert onvermijdelijk het verdwijnen van de klacht met burgerlijke partijstelling bij wijze van actie.

Hoewel de positie van het slachtoffer van groot belang is, mag deze kwestie niet beslissend zijn bij de keuze voor een bepaald stelsel van vooronderzoek. Van belang is dat de belangen van de benadeelde behoorlijk worden geregeld, welk type van vooronderzoek ook wordt gekozen. Het slachtoffer heeft vanuit internationaal oogpunt geen onvervreemdbaar recht op toegang tot het strafproces. Dat artikel 6 EVRM toepasselijk is wanneer de burgerlijke vordering voor de straf-

79 De artikelen 28sexies en 6rquater Sv.

8o Hierbij kan wel worden opgemerkt dat niet alleen de noodwendigheden van het onderzoek maar ook de omstandigheid dat de wet in de teruggave of de verbeurdverklaring van de betrokken goederen voorziet een mogelijke weigeringsgrond uitmaakt (art. 28sexies $§ 3$ Sv.). 
rechter kan worden uitgeoefend, ${ }^{8 \mathrm{r}}$ betekent niet dat het EVRM ook het recht zou inhouden voor een slachtoffer om zelf de strafvervolging in te stellen. ${ }^{82}$

Ook uit de Slachtofferrichtlijn 2012/29/EU volgt dit niet. Artikel II van deze Richtlijn vereist wel dat het slachtoffer recht heeft op toetsing van de beslissing tot niet-vervolging.

Het weze dan ook duidelijk dat een slachtoffer als dusdanig geen recht dient te hebben op de inwerkingstelling van de strafvordering of een burgerlijke partijstelling bij wijze van actie. Het EHRM heeft in alle duidelijkheid aangegeven dat er geen recht bestaat op een actio popularis: "La Cour considère que, dans pareil cas, l'applicabilité de l'article 6 atteint ses limites. Elle rappelle que la Convention ne garantit ni le droit, revendiqué par la requérante, à la 'vengeance privée', ni l'actio popularis. Ainsi, le droit de faire poursuivre ou condamner pénalement des tiers ne saurait être admis en soi: il doit impérativement aller de pair avec l'exercice par la victime de son droit d'intenter l'action, par nature civile, offerte par le droit interne, ne serait-ce qu'en vue de l'obtention d'une réparation symbolique ou de la protection d'un droit à caractère civil, à l'instar par exemple du droit de jouir d'une 'bonne réputation." 83

Binnen deze grenzen is artikel 6.I EVRM van toepassing op de vordering van een burgerlijke partij voor de strafrechter, ook in de fase van het strafrechtelijk vooronderzoek. ${ }^{8} 4$

Indien men ervoor kiest het slachtoffer een eis tot schadevergoeding te laten stellen voor de strafrechter bezit hij de minimumrechten van artikel 6.I EVRM. ${ }^{85} \mathrm{Op}$ het ogenblik dat de benadeelde toegelaten wordt zijn eis tot schadevergoeding voor de strafrechter te brengen dient immers te worden beslist over burgerlijke rechten en verplichtingen in de zin van artikel 6.I EVRM. Dit is dan ook het geval indien het nationale recht toelaat dat een slachtoffer door een burgerlijke partijstelling de strafvordering in werking stelt. ${ }^{86}$

De voordelen van dit stelsel van de burgerlijke partijstelling zijn vrij evident. ${ }^{87}$ Er wordt alzo mogelijk gemaakt dat in één en hetzelfde proces alle gevolgen van

8I Art. 6 EVRM is dan ook toepasselijk op de procedures met betrekking tot klachten met burgerlijke partijstelling, met inbegrip van de fase van het vooronderzoek (EHRM I2 februari 2004, Perez/Frankrijk, § 66, met verwijzing naar eerdere arresten van het EHRM). Het lot van de burgerlijke vordering is immers in dit geval nauw verbonden met dat van de strafvordering.

82 R. VERStRAEtEn, "De houdbaarheidsdatum van de burgerlijke partijstelling voor de onderzoeksrechter" in F. DERUYCK en M. ROZIE, Het strafrecht bedreven. Liber amicorum Alain De Nauw, Brugge, Die Keure, 20iI, 963; R. Verstraeten, D. Van Daele, A. Bailleux \& J. Huysmans, De burgerlijke partijstelling: analyse en toekomstperspectief, Antwerpen, Intersentia, 2012, 249.

83 EHRM I2 februari 2004, Perez/Frankrijk, § 70.

84 EHRM I2 februari 2004, Perez/Frankrijk, § 66; EHRM I februari 2005, Quemar/Frankrijk, § 25.

85 C. VAN DEN WyngaerT, Strafrecht en strafprocesrecht in hoofdlijnen, II, Antwerpen Maklu, 20I4, 866-867.

86 EHRM 28 oktober I998, Aït-Mouhoub/Frankrijk, § 45; EHRM 26 oktober I999, Maini/Frankrijk, \$ 28-29.

87 P. TRAEST, "Moet het strafprocesrecht een nieuwe kleur krijgen?" in De kleuren van het recht, Antwerpen, Intersentia, 2012, I82-I87. 
het misdrijf worden beslecht. Een afzonderlijk proces voor de burgerlijke rechter wordt vermeden. Proceseconomisch is deze oplossing dan ook zeker te verkiezen.

Ook biedt dit stelsel voordelen voor de benadeelde. Doordat hij zijn vordering voor dezelfde rechter brengt als de strafvordering wordt hem een burgerlijk proces bespaard en zal de uitspraak wellicht in vele gevallen sneller volgen. Ook kan de benadeelde de uitspraak van de strafrechter mee sturen en beïnvloeden en heeft hij hierbij toegang tot het strafdossier. Hoewel de straftoemeting niet het domein van de burgerlijke partij is, kan hij als burgerlijke partij ook meewerken - met de procureur als objectieve bondgenoot - aan de bewijsvoering voor de strafrechter en een eventuele vrijspraak van de beklaagde proberen te vermijden. Ook is de aanwezigheid van de benadeelde voor de strafrechter belangrijk omdat hierdoor aan het strafproces een bepaalde dimensie wordt toegevoegd ${ }^{88}$ die de strafrechter niet uit het oog mag verliezen.

Anderzijds heeft dit stelsel ook het nadeel dat de vermeerdering van het aantal procespartijen voor de strafrechter en de aanwezigheid van soms ingewikkelde juridische betwistingen omtrent de burgerlijke vordering een vertraging van het strafproces in de hand werken.

Het is duidelijk dat de rol van het slachtoffer in strafzaken aan een herziening toe is. Een volledige scheiding van de burgerlijke vordering en de strafvordering is niet gewenst. Niet alleen het genoemde voordeel op proceseconomisch vlak pleit voor de mogelijkheid de burgerlijke vordering voor de strafrechter te brengen. Ook de actuele aandacht voor de belangen van slachtoffers verhindert een volledige loskoppeling van beide vorderingen. De mogelijke betrokkenheid van de benadeelde bij het strafproces leidt dikwijls tot een beter begrip van de beslissing en kan wellicht het vertrouwen in justitie vergroten. Het is overigens duidelijk dat de publieke opinie thans moeilijk zou verdragen dat het strafproces voor het slachtoffer een ontoegankelijk gebied zou zijn.

Anderzijds kan en moet ook wel de vraag worden gesteld hoever deze betrokkenheid van het slachtoffer bij de strafvordering dient te reiken. Dat een burgerlijke partijstelling mogelijk moet blijven voor de vonnisgerechten lijkt evident. Of een rechtstreekse dagvaarding voor de vonnisgerechten behouden moet blijven is een moeilijke vraag. De strafvordering wordt hierdoor in werking gesteld waardoor een parallel ontstaat met de burgerlijke partijstelling voor de onderzoeksrechter die ook de strafvordering in werking stelt. Het toekomstige lot van de rechtstreekse dagvaarding zou dan ook verbonden moeten zijn met dit van de burgerlijke partijstelling bij wijze van actie.

Veel minder vanzelfsprekend is de bevoegdheid die thans aan de benadeelde toekomt om de strafvordering in werking te stellen. Het is een politieke beslissing om uit te maken of private partijen in staat moeten worden gesteld het hele opsporings- en vervolgingsapparaat ten behoeve van hun individuele belangen

88 M. Franchimont, A. Jacobs \& A. MAsset, Manuel de procédure pénale, Brussel, Larcier, 20I2, 204-205. 
in werking te zetten en te houden. ${ }^{89}$ Acties van de benadeelde om de strafvordering in werking te stellen doorkruisen het strafrechtelijk beleid terwijl ook de feiten die op deze manier bij de onderzoeksrechter worden aangebracht zeker niet steeds zwaarwichtig zijn. Wel impliceert de bevoegdheid voor de benadeelde om de strafvordering in werking te stellen dat deze in de latere procedure ook de bevoegdheid moet hebben om de strafvordering gaande te houden, bijvoorbeeld door hoger beroep in te stellen tegen een buitenvervolgingstelling door de raadkamer. $9^{\circ}$

Er bestaat zeker geen onvervreemdbaar recht voor de benadeelde om de strafvordering in werking te stellen. Noch de organen van de Raad van Europa, noch de Europese Unie dwingen een nationale staat tot dergelijke rechtsfiguur, zoals hoger is gebleken. Wel kan aangenomen worden dat aan het slachtoffer de kans moet worden gegeven om een beslissing van het Openbaar Ministerie tot niet-vervolging aan te vechten en te doen herzien. Dit volgt uit het reeds vermelde artikel II van de Slachtofferrichtlijn 20I2/29/EU ${ }^{\text {I }}$ maar ook uit de eerdere aanbeveling (2000)I9 van het comité van Ministers van de Raad van Europa van 6 oktober 2000 over de rol van het Openbaar Ministerie waar geoordeeld werd dat onder meer slachtoffers de mogelijkheid dienen te hebben om de beslissing van het Openbaar Ministerie om geen vervolging in te stellen te betwisten. Zulks kan volgens deze aanbeveling gebeuren, hetzij in het raam van een jurisdictionele controle, hetzij door de partijen toe te staan om zelf de vervolging in werking te stellen.

Bij wijze van voorbeeld kan verwezen worden naar de in Nederland bestaande procedure van het beklag wegens niet-vervolging (art. I2 Sv). ${ }^{2}$

De overstap naar een geïntegreerd vooronderzoek onder leiding van het Openbaar Ministerie heeft o.a. door het verdwijnen van de klacht met burgerlijke partijstelling dan ook als gevolg dat het einde van het vooronderzoek en de overgang tussen het vooronderzoek en het onderzoek ter terechtzitting aanmerkelijk eenvoudiger kan worden geregeld. Bij gebrek aan een gerechtelijk onderzoek kan de huidige logge procedure van de regeling van de rechtspleging achterwege worden gelaten. Vermits elk vooronderzoek onder leiding van het Openbaar Ministerie is

89 F. SCHuERmans, "Het vooronderzoek in strafzaken: één van die vele dringende werven van justitie" in Liber amicorum Alain De Nauw. Het strafrecht bedreven, F. DERUYCK \& M. ROZIE (eds.), Brugge, Die Keure, 20II, 795. Hierbij wordt opgemerkt dat in $75 \%$ van de gevallen de gevoerde onderzoeken tot niets leiden en dat dergelijke onderzoeken vele afspraken bijv. in het arrondissementeel rechercheoverleg doorkruisen.

go R. Verstraeten, "De houdbaarheidsdatum van de burgerlijke partijstelling voor de onderzoeksrechter" in Liber amicorum Alain De Nauw. Het strafrecht bedreven, F. DERUYCK \& M. ROZIE (eds.), Brugge, Die Keure, 2011, 963.

9I Richtlijn 20I2/29/EU van het Europees Parlement en de Raad van 25 oktober 2012 tot vaststelling van minimumnormen voor de rechten, de ondersteuning en de bescherming van slachtoffers van strafbare feiten, en ter vervanging van Kaderbesluit 200I/220/JBZ, $\mathrm{Pb} \mathrm{L}$. I4 november 2012, 57 e.v.

92 Waarbij de rechter rekening kan houden met de opportuniteit en de haalbaarheid van de vervolging (G. CORSTENs, bewerkt door M. BorGERs, Het Nederlands strafprocesrecht, Deventer, Kluwer, 2014, 619-630; S. VERHELST, De rol van het slachtoffer in het straf(proces)recht, Antwerpen, Intersentia, 2013, 252-263). 
geschied zijn er bij het einde van het vooronderzoek slechts twee mogelijkheden, afhankelijk van de inzichten van het Openbaar Ministerie.

Ofwel oordeelt het Openbaar Ministerie dat er geen verdere vervolging dient te worden uitgeoefend, ofwel wenst het Openbaar Ministerie als gevolg van het gevoerde vooronderzoek en de resultaten ervan de beklaagde voor het vonnisgerecht te dagen. De eerste hypothese is vanzelfsprekend de meest delicate aangezien in dat geval het slachtoffer zich benadeeld kan voelen, zeker bij gebrek aan mogelijkheid van een burgerlijke partijstelling voor de onderzoeksrechter.

Wanneer het Openbaar Ministerie oordeelt niet verder te moeten vervolgen dient het de benadeelde persoon en de verdachte over dit voornemen te informeren en hun het recht te verlenen om het dossier in te zien en er eventueel een kopie van te nemen. Vermits er geen duidelijke categorie van inverdenkinggestelden meer zal zijn past het alle personen in te lichten die in de loop van het vooronderzoek als verdachten werden verhoord.

De in kennis gestelde partijen beschikken dan over een bij de wet bepaalde termijn om op basis van de inzage in het dossier bijkomende onderzoekshandelingen te vorderen van de procureur des Konings. Naar analogie met dit recht tijdens het vooronderzoek kan ook in deze fase in geval van weigering hoger beroep worden aangetekend bij de onderzoeksrechter. Na uitvoering van de eventueel bevolen aanvullende onderzoeksdaden kunnen de partijen opnieuw het dossier inzien.

Voor het slachtoffer wordt op dit ogenblik van de procedure voorzien in het recht om op te komen tegen het voornemen van het Openbaar Ministerie om niet verder te vervolgen. Tegen dit voornemen kan de benadeelde persoon opkomen voor de kamer van inbeschuldigingstelling. Hierbij dient hij op gemotiveerde wijze aan te geven welke de inbreuk is en welke verdachten naar zijn oordeel zouden dienen te worden vervolgd.

Wanneer de kamer van inbeschuldigingstelling eenparig oordeelt dat het beroep manifest onontvankelijk of ongegrond is kan zij zonder debat het beroep afwijzen, als gevolg waarvan de beslissing van het Openbaar Ministerie overeind blijft. In het andere geval bepaalt zij een termijn voor het indienen van een schriftelijk verweer en een datum voor een zitting, waardoor een tegensprekelijke procedure volgt.

De redenen die een afwijzing van het beroep van het slachtoffer kunnen wettigen zijn van diverse aard. Enerzijds kunnen er redenen van technische aard zijn die het verderzetten van de vervolging onmogelijk maken. Hierbij kan bijvoorbeeld gedacht worden aan de verjaring. Anderzijds kan de beslissing van het Openbaar Ministerie om niet te vervolgen worden bevestigd indien deze beslissing conform is aan de beginselen van proportionaliteit en subsidiariteit. Deze criteria zijn niet nieuw nu ook in het ontwerp van wetboek van strafprocesrecht uit 2005 op deze begrippen een beroep werd gedaan om de functie van de raadkamer te omschrijven wanneer deze - volgens het toenmalige voorstel - zou moeten oordelen over de vraag of een ingediende klacht met burgerlijke partijstelling al dan 
niet gevolgd moet worden door een gerechtelijk onderzoek onder de leiding van de onderzoeksrechter. ${ }^{93}$

Indien de verdachte - al of niet na een tussenkomst van de kamer van inbeschuldigingstelling - buiten vervolging is gesteld kan hier enkel op teruggekomen worden in geval van het bestaan van nieuwe bezwaren. Hierbij dient het vanzelfsprekend te gaan om elementen die niet aan de kamer van inbeschuldigingstelling konden worden voorgelegd.

Indien het beroep van de benadeelde wordt ingewilligd beveelt de kamer van inbeschuldigingstelling dat door het parket tot dagvaarding wordt overgegaan.

Wanneer het beroep wordt afgewezen kan de benadeelde cassatieberoep instellen tegen het arrest van de kamer van inbeschuldigingstelling.

Wanneer het Openbaar Ministerie bij het einde van het vooronderzoek beslist om verder te vervolgen kan worden volstaan met het verlenen van inzage in het strafdossier aan de verdachten en de benadeelde partijen met de mogelijkheid om te verzoeken om de uitvoering van eventuele bijkomende onderzoeksdaden. Ook in deze hypothese kan bij afwijzing van de gevraagde onderzoekshandelingen hoger beroep worden ingesteld bij de onderzoeksrechter.

$\mathrm{Na}$ de eventuele uitvoering van bijkomende onderzoeksdaden kan dan tot dagvaarding worden overgegaan.

\section{De bevoegdheden}

De bevoegdheden die tijdens het vooronderzoek kunnen worden uitgeoefend worden in het Wetboek van Strafvordering op een weinig overzichtelijke wijze weergegeven. Dit heeft alles te maken met de structuur van het wetboek zelf, dat geconcipieerd is met het principiële uitgangspunt dat het gerechtelijk onderzoek onder leiding van een onderzoeksrechter de norm is en de bevoegdheden van de procureur des Konings eerder uitzonderlijk, met name wanneer een situatie van heterdaad voorligt. Dit heeft als gevolg dat, niettegenstaande de bestaande twee types van vooronderzoek in het wetboek, geen systematische uiteenzetting voorkomt van de bevoegdheden die door de procureur des Konings en de onderzoeksrechter elk in het kader van de hun toekomende leiding van het vooronderzoek kunnen worden uitgeoefend. Evenmin bevat het wetboek een overzicht van

93 Volgens dat voorstel uit 2005 zou de procureur des Konings de raadkamer kunnen adiëren "omdat de opening van een gerechtelijk onderzoek en de uitvoering van de onderzoeksdaden die daaruit voortvloeien niet in overeenstemming zijn met de beginselen van proportionaliteit en subsidiariteit bedoeld in artikel 1 van het wetboek" (art. I42 $\$ 2.3^{\circ}$ van het ontwerp). De Commissie strafprocesrecht was van oordeel dat de klacht met burgerlijke partijstelling een bescherming vormt tegen een eventuele inertie van het parket en dat de garantie geboden moet worden dat de klacht in elk geval ooit eens wordt onderzocht door een rechter, ook al mondt dit onderzoek uit in de beslissing dat de klacht geen doorgang zal vinden. Het weze duidelijk dat dit voorstel het voortbestaan impliceerde van het gerechtelijk onderzoek in zijn huidige vorm. 
de bevoegdheden die door de procureur des Konings buiten de heterdaadsituatie kunnen worden toegepast.

De essentie van de onderzoeksbevoegdheden bevindt zich in de hoofdstukken IV, IVbis en $\mathrm{V}$ van Boek I wat de procureur des Konings betreft (de artikelen 22 tot en met 54 Sv.) en hoofdstuk VI van Boek I wat de onderzoeksrechter betreft (de artikelen 55 tot en met goduodecies Sv.). Daarnaast bevat ditzelfde Boek I nog hoofdstukken over de voorlopige maatregelen ten aanzien van rechtspersonen, het verhoor van minderjarigen die slachtoffer of getuige zijn van bepaalde misdrijven, de bescherming van bedreigde getuigen en het afnemen van verklaringen met behulp van audiovisuele middelen. De structuur is zodoende niet duidelijk aangezien een rudimentaire indeling op grond van de bevoegdheden van de leidende magistraten wordt aangevuld met bepalingen gestructureerd volgens hun inhoud.

In het ontwerp van wetboek van strafprocesrecht uit 2005 werd ervoor geopteerd om de onderzoeksbevoegdheden in het opsporingsonderzoek en het gerechtelijk onderzoek in een afzonderlijke titel te omschrijven. Dit heeft als gevolg dat onderzoeksbevoegdheden die zowel door de procureur des Konings als door de onderzoeksrechter kunnen worden aangewend (bijv. de aanstelling van een deskundige) op twee plaatsen worden behandeld maar deze werkwijze komt de duidelijkheid ongetwijfeld ten goede.

Bij de optie voor een geïntegreerd vooronderzoek onder leiding van het Openbaar Ministerie rijst dit probleem niet meer. Logischerwijze wordt dan geopteerd voor een opsomming van de onderzoeksbevoegdheden die ter beschikking staan van het Openbaar Ministerie aangevuld met een opsomming van de gevallen waarin een machtiging moet worden bekomen van de onderzoeksrechter, evenals de procedure die hiervoor moet worden gevolgd.

\section{I Bevoegdheden tot vrijheidsbeperking en vrijheidsbeneming}

\subsubsection{Huidige toestand}

De actuele regeling van de voorlopige hechtenis in België is ondergebracht in de Wet betreffende de Voorlopige Hechtenis van 20 juli I990. ${ }^{94}$

Deze wet regelt meerdere aangelegenheden die te maken hebben met vrijheidsberoving en vrijheidsbeperking. Zo wordt in deze wet ook de aanhouding (de arrestatie) geregeld evenals het bevel tot medebrenging en het eigenlijke bevel tot aanhouding. De modernisering van het Wetboek van Strafvordering vereist ongetwijfeld dat de in de Voorlopige hechteniswet geregelde aangelegenheden in het wetboek zelf worden geregeld. Ook bestaat er geen enkele betwisting over het feit dat in een stelsel van een geïntegreerd vooronderzoek onder leiding van het Openbaar Ministerie de bevoegdheid tot vrijheidsberoving of -beperking bij een

94 Deze wet is in de plaats gekomen van eerdere wetten die dezelfde aangelegenheid regelden, zoals de wet van 20 april 1874 . 
rechter dient te liggen, vanzelfsprekend met uitzondering van de bevoegdheid om een persoon te arresteren. Artikel I2 van de Grondwet vereist overigens dat de vrijheidsberoving van een persoon (arrestatie) zonder een rechterlijk bevel een beperkte duur heeft.

Tot voor kort was deze grens vastgelegd op 24 uur doch in de nabije toekomst zal de arrestatietermijn op 48 uren worden gebracht waarbij ook artikel I2 van de Grondwet in deze zin zal worden aangepast. ${ }^{95}$

De in beginsel geldende termijn van 24 uur kon reeds sedert de wet van I3 augustus $20 \mathrm{II}^{96}$ die artikel ${ }^{5} 5$ bis in de Voorlopige hechteniswet invoerde, verlengd worden met een termijn van ten hoogste 24 uur zodat reeds onder de gelding van dit stelsel een arrestatie 48 uren kon duren. De termijn van 24 of 48 uur is een maximumtermijn. Ook is de rechtspositie van de gearresteerde persoon door de Salduzwetten van I3 augustus 20II en 2I november 2016 aanzienlijk verbeterd, in het bijzonder tijdens de periode van arrestatie.

Het verlengen van de arrestatietermijn naar 48 uren lijkt te kunnen worden verantwoord. Er dient inderdaad rekening te worden gehouden met de realisatie van het recht op bijstand van de advocaat, wat hoe dan ook enige vertraging met zich kan brengen. De toegenomen tegenspraak die hiervan het gevolg is kan het ook noodzakelijk maken om binnen de arrestatietermijn bijkomende onderzoekshandelingen te stellen vooraleer de betrokkene voor de onderzoeksrechter wordt geleid.

Bovendien kan acht worden geslagen op de internationale context, waarbij in vele andere landen een arrestatietermijn van 48 uur aangenomen wordt. Het spreekt voor zich dat deze verlenging geen aanleiding tot misbruik mag geven. Zoals nu dient in de wet aangegeven te blijven dat de gearresteerde persoon in vrijheid dient te worden gesteld zodra de maatregel van vrijheidsberoving niet meer noodzakelijk is. In dit verband zal de toegenomen rechtsbescherming van de gearresteerde persoon, niet in het minst door de toekenning van de zogenoemde Salduz-rechten, ook tot gevolg hebben dat misbruiken zullen kunnen worden tegengegaan.

Indien de arrestatietermijn wordt verlengd tot 48 uren is het logisch dat het bevel tot verlenging, waarvan hoger sprake, zal komen te vervallen. Anders zou de arrestatie kunnen worden verlengd tot 72 uren, wat overdreven en niet verantwoord lijkt. Een voorstel om de arrestatietermijn voor terroristische misdrijven op 72 uren vast te leggen werd trouwens recent op 15 juni 2017 in het Belgische parlement niet aangenomen.

95 Zie in dit verband het ontwerp tot herziening van art.I2 van de Grondwet, dat reeds werd aangenomen in de kamer van volksvertegenwoordigers en aan de Senaat werd overgezonden Parl. St. Senaat, 54, 26ri/oo6, 20 juli 20I7, voor de aan de Senaat overgezonden tekst.

96 Met name de Salduz-wet. 
Waar de artikelen I en 2 van de Voorlopige Hechteniswet de arrestatie regelen, wordt de eigenlijke voorlopige hechtenis geregeld vanaf artikel 16 van de wet. ${ }^{97}$

De eigenlijke voorlopige hechtenis neemt een aanvang met het bevel tot aanhouding, zoals geregeld in artikel I6 van de wet. Een dergelijk bevel dat door de onderzoeksrechter wordt afgeleverd vereist de aanwezigheid van een aantal grond- en vormvoorwaarden.

Er dienen immers ernstige schuldaanwijzingen te zijn wegens een misdrijf dat strafbaar is met een gevangenisstraf van één jaar of meer..$^{8}$ Een wijziging van deze drempelstraf is niet voor de hand liggend en leent zich ook moeilijk tot een vergelijking met andere landen omdat een en ander sterk afhankelijk is van de strafschalen die in het materieel strafrecht worden gehanteerd.

De aanhouding dient tevens noodzakelijk te zijn voor de openbare veiligheid en indien de op het misdrijf staande straf de vijftien jaar opsluiting niet te boven gaat, mag een dergelijk bevel slechts worden verleend als er wettelijke redenen aanwezig zijn, met name recidivegevaar, vluchtgevaar, verduisteringsgevaar of collusiegevaar (art. I6 § I in fine Voorlopige Hechteniswet). ${ }^{99}$

De vormvoorwaarden voor het bevel tot aanhouding zijn niet minder belangrijk. Zo dient de onderzoeksrechter persoonlijk de verdachte te ondervragen alvorens een bevel tot aanhouding te verlenen en dient hij deze verdachte in zijn opmerkingen te horen. ${ }^{\text {Ioo }} \mathrm{Bij}$ ontstentenis van deze ondervraging wordt de verdachte in vrijheid gesteld. Het aanhoudingsbevel dient tevens gemotiveerd te zijn en dient binnen de 24 uur (in de nabije toekomst 48 uur) vanaf de vrijheidsbeneming aan de verdachte te worden betekend. Bij ontstentenis van regelmatige betekening binnen de wettelijke termijn wordt de verdachte in vrijheid gesteld.

De onderzoeksrechter bepaalt of het bevel tot aanhouding moet worden uitgevoerd in een gevangenis dan wel door een hechtenis onder elektronisch toezicht. Dit laatste impliceert dat de onderzoeksrechter ook de toegestane verplaatsingen bepaalt. Elke dag in elektronisch toezicht staat gelijk met een dag in de gevangenis doch de onderzoeksrechter heeft de bevoegdheid om in elke stand van het

97 Binnen het bestek van deze bijdrage kan niet nader worden ingegaan op de voorwaarden tot arrestatie noch op de regeling omtrent de bijstand van een advocaat voor de gearresteerde persoon. Hiervoor kan verwezen worden naar de artikelen I (arrestatie op heterdaad), 2 (arrestatie buiten heterdaad) en 2 bis (toegang tot een advocaat tot en met de betekening van het door de onderzoeksrechter afgeleverde bevel tot aanhouding).

98 Hierbij volstaat het dat een straf van één jaar wettelijk mogelijk is zodat een misdrijf dat strafbaar is met een maximale gevangenisstraf van één jaar in aanmerking komt voor voorlopige hechtenis. In de voorlopige hechteniswet van I874 was de drempelstraf op drie maanden vastgesteld doch met deze grens kwamen vrijwel alle misdrijven voor voorlopige hechtenis in aanmerking.

99 Deze ernstige en wettelijk bepaalde redenen zijn niet cumulatief zodat de gemotiveerde vaststelling door de onderzoeksrechter van de aanwezigheid van een van deze omstandigheden volstaat. Deze bijkomende voorwaarde geldt niet voor de terroristische misdrijven.

Ioo Ook de advocaat die bij het verhoor aanwezig is, dient in zijn opmerkingen te worden gehoord over de mededeling dat tegen de verdachte een aanhoudingsbevel kan worden uitgevaardigd (art. I6 5 2, vijfde lid). 
geding, ambtshalve of op vordering van de procureur des Konings, te bevelen dat het elektronisch toezicht wordt omgezet in een hechtenis die in de gevangenis wordt uitgevoerd. ${ }^{\text {ror }}$

Als eenmaal door de onderzoeksrechter een aanhoudingsbevel is uitgevaardigd wordt het verdere verloop van de voorlopige hechtenis onderworpen aan een stelsel van rechterlijk toezicht dat automatisch wordt toegepast, met name zonder dat dit toezicht afhankelijk is van enig initiatief van de zijde van de aangehouden inverdenkinggestelde. Hoewel aan dit stelsel door de zgn. Potpourri II-wet van 5 februari 2016 een aantal wijzigingen werd aangebracht bestaat in België geen draagvlak voor het volledig loslaten van dit stelsel en om de rechterlijke controle afhankelijk te maken van een of andere vorm van initiatief van de aangehoudene. ${ }^{102}$

Tegen het aanhoudingsbevel op zich staat geen rechtsmiddel open maar de geldigheidsduur van een dergelijk bevel tot aanhouding is beperkt tot vijf dagen. Voor het verstrijken van deze termijn dient een rechterlijke controle plaats te vinden voor de raadkamer, waarbij een wettigheidscontrole ${ }^{103}$ en een opportuniteitscontrole worden uitgevoerd. Deze laatste controle houdt in dat de raadkamer niet alleen oordeelt over de handhaving van de voorlopige hechtenis maar ook over de modaliteiten van uitvoering ervan, wat impliceert dat de raadkamer bij die gelegenheid een voorlopige hechtenis in de gevangenis kan omzetten in een elektronisch toezicht en omgekeerd. De beschikking tot handhaving is één maand geldig vanaf de dag waarop ze wordt gegeven.

Vervolgens oordeelt de raadkamer van maand tot maand en vanaf de derde beslissing - sedert de wet van 5 februari 2016 - om de twee maanden over de handhaving van de voorlopige hechtenis en de modaliteit van uitvoering ervan. Deze periodieke controle neemt enkel de vorm aan van een opportuniteitscontrole. Tegen elke beslissing van de raadkamer in het kader van het toezicht op de voorlopige hechtenis kan hoger beroep worden aangetekend bij de kamer van inbeschuldigingstelling, zowel door de aangehouden verdachte als door het Openbaar Ministerie. Voorafgaand aan elke beslissing bestaat voor de aangehouden verdachte een inzagerecht in het dossier. ${ }^{104}$

Hoewel de wet zulks niet uitdrukkelijk bepaalt, kan de kamer van inbeschuldigingstelling ook oordelen over de modaliteiten van de voorlopige hechtenis. Zo kan de kamer van inbeschuldigingstelling op het hoger beroep van het Openbaar

IOI Deze beslissing is onderworpen aan bepaalde toepassingsvoorwaarden, zoals o.a. de nietnaleving van de standaardinstructies en de regels van de hechtenis onder elektronisch toezicht (art. 24bis Voorlopige hechteniswet).

I02 Hoewel art. 5 EVRM zulks niet zou verbieden.

I03 Met name of het aanhoudingsbevel regelmatig is ten aanzien van de bepalingen van de Voorlopige Hechteniswet.

IO4 Voor de raadkamer is zulks uitdrukkelijk bepaald in de art. 2I en 22 van de Voorlopige Hechteniswet. Voor de kamer van inbeschuldigingstelling voorziet art. 30 van de wet niet in een nieuw inzagerecht, wat geen schending van het recht van verdediging uitmaakt indien ondertussen geen nieuwe stukken aan het dossier werden toegevoegd (bijv. Cass. 27 juni 2000, Arr. Cass. 2000, 408). 
Ministerie beslissen dat een voorlopige hechtenis waarvan de raadkamer had geoordeeld dat deze in elektronisch toezicht wordt uitgevoerd, toch in de gevangenis moet worden uitgevoerd. ${ }^{105}$

Waar tot voor kort tegen de beslissing van de kamer van inbeschuldigingstelling cassatieberoep kon worden ingesteld, is zulks nu sedert de Potpourri II-wet van 5 februari 2016 nog enkel mogelijk tegen de beslissing die de wettigheid van het bevel tot aanhouding nagaat.

\subsubsection{In een geïntegreerd vooronderzoek}

In een stelsel van één geïntegreerd vooronderzoek onder de leiding van het Openbaar Ministerie lijkt het vanzelfsprekend dat de onderzoeksrechter de instantie blijft die oordeelt over de aflevering van een aanhoudingsbevel. In dergelijk vernieuwd vooronderzoek zal een aanhoudingsbevel enkel kunnen worden uitgevaardigd op een gemotiveerde vordering van de procureur des Konings. Dat deze bevoegdheid toekomt aan een alleenzetelend rechter is niet problematisch, gelet op het bestaan van een rechterlijk toezicht en het feit dat de betrokken rechter het onderzoek zelf niet meer zal leiden.

Een dergelijke vordering van het Openbaar Ministerie zal schriftelijk moeten gebeuren en zal gepaard moeten gaan met de overhandiging van het dossier aan de onderzoeksrechter.

De arrestatietermijn gaat in geval van heterdaad in op het ogenblik dat de verdachte niet meer beschikt over de vrijheid van komen en gaan en buiten heterdaad in beginsel op het ogenblik van de kennisgeving van de beslissing tot vrijheidsbeneming. Dat het juiste uur van vrijheidsbeneming zoals nu in het proces-verbaal nauwkeurig zal moeten worden aangegeven is vanzelfsprekend.

De ondervraging van de verdachte door de onderzoeksrechter persoonlijk blijft een belangrijke en zelfs essentiële garantie die zoals nu rechtvaardigt dat de sanctie op de niet-nakoming van deze verplichting de invrijheidstelling van de verdachte is. Voorafgaand aan deze ondervraging door de onderzoeksrechter heeft de gearresteerde persoon wel het recht om gedurende dertig minuten een vertrouwelijk overleg te hebben met zijn advocaat.

Er werd tevens voorzien - wat nieuw is - dat het dossier ter beschikking wordt gesteld van de verdachte en zijn advocaat zodra het bevel tot aanhouding wordt gevorderd. Zulks kan natuurlijk ook in de vorm van eensluidend verklaarde afschriften. Dit is aangewezen om het verhoor te optimaliseren nu de verdachte en zijn advocaat worden gehoord over de wenselijkheid en de mogelijkheid om een bevel tot aanhouding af te leveren. Het is dan ook aangewezen dat ook de verdachte op dat moment zou weten welke elementen in het dossier reeds aanwezig

I05 Cass. 28 januari 20I4, P.I4.oI28.N. 
zijn. De procureur des Konings heeft overigens ook het recht deze ondervraging bij te wonen.

De onderzoeksrechter die in deze omstandigheden zal beslissen over een bevel tot aanhouding zal het dossier even goed kennen als dat thans het geval is in het kader van een gerechtelijk onderzoek. Vooreerst wordt van de onderzoeksrechter nu ook dikwijls een bevel tot aanhouding gevorderd in het begin van het onderzoek en samen met de vordering tot onderzoek. Het dossier is in die hypothese ook voor de onderzoeksrechter in het huidige stelsel volkomen nieuw. Bovendien zal in complexe dossiers de onderzoeksrechter reeds voor het afleveren van een bevel tot aanhouding het dossier hebben leren kennen naar aanleiding van de vraag tot het machtigen van bepaalde onderzoeksdaden, bijvoorbeeld een huiszoeking. Ten slotte zal de motivering in de vordering van het Openbaar Ministerie de onderzoeksrechter ook de nodige elementen aanreiken. Het is aldus niet aannemelijk dat de informatiepositie van de onderzoeksrechter in een geïntegreerd vooronderzoek minder goed zal zijn als deze van de onderzoeksrechter in het actuele gerechtelijk onderzoek.

Er bestaat niet onmiddellijk een noodzaak om de hoger geschetste grondvoorwaarden voor de voorlopige hechtenis, en in het bijzonder de (alternatieve) wettelijke redenen ingeval de feiten met ten hoogste vijftien jaar opsluiting worden bestraft, ingrijpend te veranderen. Wel kan het aangewezen zijn om de aanwezigheid van minstens een van deze vier wettige redenen ook te vereisen indien het gaat om een ernstiger misdrijf en dus dit vereiste te veralgemenen voor alle bevelen tot aanhouding. Evenmin wordt de noodzaak aangevoeld om de drempelstraf van één jaar, die thans vereist is om een bevel tot aanhouding te kunnen afleveren op te trekken. Dat deze grens laag genoemd kan worden staat buiten kijf, zeker nu het zoals hoger aangegeven volstaat dat het maximum van de in de wet bepaalde straf deze grens bereikt en de straffen in het materieel strafrecht vrij hoog liggen. Anderzijds moet ook rekening worden gehouden met het feit dat de strafschalen in het materieel strafrecht worden onderzocht en het te verwachten valt dat deze straffen op een meer coherente manier zullen worden ingevuld. ${ }^{\text {Io6 }}$

Voorts is het verdedigbaar te stellen dat de noodzaak tot het afleveren van een bevel tot aanhouding een beslissing is die dient te worden genomen op basis van de concrete gegevens van het dossier en de persoon van de verdachte en dat, veeleer dan de drempelstraf te verhogen, een evenwichtige toepassing van de voorlopige hechtenis bereikt kan worden door de inhoudelijke criteria voor het afleveren van dergelijk bevel aan te scherpen.

De betekening van het bevel tot aanhouding zal dienen te gebeuren binnen een termijn van 48 uren.

Io6 Zie in dit verband het voorstel van voorontwerp van Boek I van het Strafwetboek, uitgewerkt door J. ROzIE \& D. VANDERMEERSCH, Commission, de réforme du droit pénal, proposition d'vant-projet de livre Ier du Code pénal, La Charte, 20I6, I75 p. 
Zoals voorheen zal het bevel tot aanhouding geldig zijn voor een periode van vijf dagen, waarbinnen de raadkamer zowel de regelmatigheid van het bevel tot aanhouding als de opportuniteit van de handhaving ervan zal dienen te beoordelen. De beslissing van de raadkamer zal gelden voor één maand terwijl een hoger beroep bij de kamer van inbeschuldigingstelling mogelijk zal blijven.

De bevoegdheid die de onderzoeksrechter thans op grond van artikel 25 van de Voorlopige Hechteniswet heeft om op elk moment handlichting te verlenen en de verdachte in vrijheid te stellen dient in een stelsel van een eengemaakt vooronderzoek onder leiding van het Openbaar Ministerie te worden aangepast. Deze bevoegdheid zal alsdan toekomen aan de procureur des Konings, waarbij evenmin een rechtsmiddel mogelijk is. Overigens ziet men niet goed in wie een belang zou hebben om tegen deze beslissing op te komen. De onderzoeksrechter zou deze bevoegdheid ook nog behouden telkens hij gevat wordt met het dossier. Bij deze gelegenheid zou hij ook kunnen beslissen dat de voorlopige hechtenis die in de gevangenis wordt uitgevoerd vanaf dat moment zal worden uitgevoerd onder elektronisch toezicht.

In een stelsel waar de leiding van het vooronderzoek niet meer berust bij een rechter kan de rechterlijke controle op de handhaving van de voorlopige hechtenis een andere vorm aannemen dan nu het geval is. Meer bepaald kan vanaf de tweede handhaving ${ }^{107}$ de controle over de opportuniteit van de verdere handhaving van de voorlopige hechtenis in handen gegeven worden van de onderzoeksrechter. Ter gelegenheid van een dergelijke controle kan een procedure worden toegepast die gelijkaardig is aan de huidige procedure voor de raadkamer, derhalve met inbegrip van inzage in het dossier voorafgaand aan de zitting voor de onderzoeksrechter.

Tegen de beslissing van de onderzoeksrechter kan vervolgens hoger beroep worden aangetekend bij de kamer van inbeschuldigingstelling zoals ook nu het geval is tegen de beslissingen van de raadkamer.

Bij een modernisering van het Wetboek van Strafvordering dient ook de vraag te worden gesteld of het huidig stelsel van de periodieke controle op de voorlopige hechtenis integraal dient te worden overgenomen. Met de Potpourri II-wet van 5 februari 2016 werd zoals aangegeven de frequentie van de automatische controle vanaf de derde handhaving teruggebracht tot een controle om de twee maanden terwijl het cassatieberoep tegen de beslissingen tot handhaving werd opgeheven, met uitzondering van het cassatieberoep tegen de eerste handhaving, waarbij ook de wettigheid van het aanhoudingsbevel wordt gecontroleerd.

De vraag naar de noodzaak van en de frequentie van de periodieke controles is een vraag die een evenwichtig antwoord verdient. Het EVRM noch enige andere supranationale bepaling verplicht de nationale wetgever te voorzien in een sys-

I07 De eerste handhaving betreft ook de controle op de wettigheid van het bevel tot aanhouding zodat deze niet aan de onderzoeksrechter kan worden toevertrouwd. 
teem van automatische controle op de voorlopige hechtenis. Ook dient men de belasting van de nationale gerechtelijke instanties in rekening te brengen.

Anderzijds betreft de voorlopige hechtenis een stelsel waarbij een bij uitstek fundamenteel rechtsgoed, met name de persoonlijke vrijheid, wordt aangetast en op een ogenblik dat de schuld van de verdachte nog niet vastgesteld werd en deze dus voor onschuldig wordt gehouden. Dit gegeven pleit er dan ook voor een regelmatige controle op de voorlopige hechtenis mogelijk te maken met een maximalisatie van de rechtsmiddelen in dit verband. Er zijn dus goede argumenten om bij een modernisering van het Wetboek van Strafvordering terug te keren naar een stelsel van maandelijkse controle op de voorlopige hechtenis zolang het onderzoek duurt en aan de voorlopige hechtenis geen einde werd gemaakt. Om dezelfde reden verdient het aanbeveling om opnieuw tegen elke beslissing van de kamer van inbeschuldigingstelling inzake de voorlopige hechtenis een cassatieberoep mogelijk te maken. Dat hiermee een zekere werklast voor de hoven en rechtbanken gepaard gaat, is duidelijk doch anderzijds moet zulks ook gerelativeerd worden nu blijkt dat $75 \%$ van de gevallen van voorlopige hechtenis beperkt blijft tot drie maanden of minder.$^{108}$ Aldus kan bezwaarlijk gezegd worden dat een uitgebreide periodieke controle op de voorlopige hechtenis zoals deze tot voor de wet van 5 februari 2016 bestond onoverkomelijke moeilijkheden voor de werking van het justitieel apparaat met zich zou brengen.

\subsection{De verdenkingscriteria}

De voorlopige hechtenis en de drempel die daaraan wordt gesteld doen ook de vraag rijzen naar het bestaan van verdenkingscriteria die de aanwending van bepaalde onderzoeksmethoden normeren. Bestaat er enige systematiek in de vereisten waaraan moet zijn voldaan om een bepaalde onderzoeksbevoegdheid te kunnen aanwenden? De noodzaak van dergelijke criteria vloeit rechtstreeks voort uit het beginsel van de proportionaliteit dat gebiedt dat naarmate het indringend karakter van een bepaalde bevoegdheid toeneemt ook de drempel stijgt waaraan moet zijn voldaan om deze bevoegdheid toe te passen. Dit beginsel geldt dan ook wanneer het gaat om een bevoegdheid die, omwille van de aantasting van een fundamenteel recht, enkel door een rechter kan worden bevolen.

Er bestaat geen onmiddellijk verband tussen de drempels die in de voorlopige hechtenis zijn ingebouwd - mogelijke straf van één jaar voor een aanhoudingsbevel en de grens van vijftien jaar boven dewelke aan de motivering van het bevel tot aanhouding minder eisen gesteld worden - en de aanwending van opsporingsbevoegdheden. Zulks is niet verwonderlijk aangezien de drempel van één jaar gevangenisstraf vrij laag is en in elk geval niet kan gelden voor de aanwending van de eerder indringende onderzoeksbevoegdheden.

Io8 I. Mennes, "Wijzigingen aan de voorlopige hechtenis" in J. Decoker, L. Gyselaers, P. Hoet, J. Coppens, F. Vroman, M. Vandermeersch, T. Decaigny, T. Bauwens, C. Van De Heyning, B. De Smet, G. Schoorens, B. Meganck, H. Van Bavel, E. Baeyens, I. Mennes \& J. Millen, "De wet van 5 februari 2016 tot wijziging van het strafrecht en de strafvordering houdende diverse bepalingen inzake justitie (Potpourri II), gewikt en gewogen”, T.Strafr. 20I6, 5 . 
Er zijn vooreerst een aantal 'alledaagse' opsporingsbevoegdheden waarvoor helemaal geen uitgewerkt verdenkingscriterium bestaat. Het gaat hierbij om bevoegdheden die enkel het vermoeden van het bestaan van een misdrijf vereisen zonder dat vereist wordt dat dit misdrijf met een bepaalde straf wordt beteugeld. Bij wijze van voorbeeld kan verwezen worden naar het opnemen van klachten en aangiften (art. 3I Sv.), de identiteitscontrole en het houden van gegevensbestanden, ${ }^{\text {I09 }}$ het doorzoeken van voertuigen, ${ }^{\text {IIo }}$ de gewone observatie, de ondervraging van een verdachte of een getuige, de toekenning van het statuut van gedeeltelijk anonieme getuige (art. 75bis Sv.), ${ }^{\text {III }}$ het deskundigenonderzoek, het DNA-onderzoek op voorstel van de procureur des Konings en met toestemming van de betrokkene (art. 44quater Sv.), het onderzoek aan het lichaam (art. gobis Sv.), ${ }^{112} \mathrm{de}$ huiszoeking, de inbeslagneming, het databeslag en de zoeking in een informaticasysteem (art. 39bis $\$ 2-4$ Sv.), ${ }^{113}$ de uitgestelde tussenkomst, de informantenwerking, de voorlopige maatregelen ten aanzien van rechtspersonen (art. 9I Sv.), ${ }^{\mathrm{II}}$ het beknopt voorlichtingsrapport en de maatschappelijke enquête.

De in de Voorlopige Hechteniswet aangewende drempelstraf van één jaar gevangenisstraf wordt voor een aantal opsporingsbevoegdheden gebruikt, hoewel het verband met de voorlopige hechtenis niet duidelijk blijkt. Net zoals de drempel voor de voorlopige hechtenis kan ook in dit verband worden gezegd dat deze drempel geen noemenswaardige belemmering uitmaakt voor de aanwending van deze bevoegdheden. Het gaat hierbij om het inwinnen van gegevens over bankrekeningen en -transacties (art. 46quater $§$ I, eerste lid Sv.), het forensisch psychiatrisch deskundigenonderzoek met opneming ter observatie (art. 6 § I Interneringswet van 5 mei 20I4), ${ }^{115}$ het onderscheppen van post (art. 46ter $\S$ I, eerste lid Sv.), het lezen van post (art. 88sexies $\S$ I, eerste lid juncto art. 46ter $\S$ I, eerste lid Sv.), ${ }^{\mathrm{rl} 6}$ de identificatie van gebruikers van telecommunicatie (art. $46 \mathrm{bis}$

Io9 Respectievelijk de art. 34 en 44/2 en 44/3 van de Wet Politieambt.

IIo Art. 29 Wet Politieambt. Hierbij volstaat het dat er op grond van de gedragingen van de bestuurder of passagiers, van materiële aanwijzingen of van omstandigheden van tijd of plaats redelijke gronden zijn om te denken dat het voertuig gebruikt wordt of zou kunnen worden gebruikt om een misdrijf te plegen. Andere vermoedens kunnen een dergelijke maatregel ook verantwoorden, zoals het vermoeden dat het voertuig gebruikt wordt om opgespoorde personen of personen die aan een identiteitscontrole willen ontsnappen een schuilplaats te geven of te vervoeren of het vermoeden dat het voertuig gebruikt wordt om een voor de openbare orde gevaarlijk voorwerp, overtuigingsstukken of bewijsmateriaal in verband met een misdrijf op te slaan of te vervoeren.

III Hoewel in deze bepaling geen drempelstraf voorkomt, moet worden opgemerkt dat het gaat om een bevoegdheid van de onderzoeksrechter.

II2 Ook hier gaat het om een bevoegdheid van de onderzoeksrechter.

II3 De zoeking in een informaticasysteem kan bevolen worden door een officier van gerechtelijke politie. De uitbreiding van de zoeking tot een informaticasysteem dat zich op een andere plaats bevindt, dient te worden bevolen door de procureur des Konings indien deze uitbreiding zich niet verder uitstrekt dan tot de systemen waartoe de personen die gerechtigd zijn het onderzochte informaticasysteem te gebruiken in het bijzonder toegang hebben (art. 39bis \$3 Sv.). In de andere gevallen dient de onderzoeksrechter tussen te komen (art. 39bis $\S_{4} \mathrm{~Sv}$.).

II4 Het gaat ook hier om een bevoegdheid van de onderzoeksrechter.

II5 Indien het forensisch psychiatrisch deskundigenonderzoek geen opname vereist, volstaat dat het misdrijf een misdaad of wanbedrijf uitmaakt.

II6 De drempelstraf voor het onderscheppen van post en het openen van post is dezelfde maar het openen van de post is een bevoegdheid van de onderzoeksrechter. 
§ I Sv.), ${ }^{117}$ het opsporen en lokaliseren van elektronische communicatie (art. 88bis § I, eerste lid Sv.), de stelselmatige observatie met technische hulpmiddelen (art. 47 sexies $§ 2$, tweede lid Sv.) en de infiltratie of interactie op internet (art. 46sexies S I, eerste lid Sv.).

Een grens van vijf jaar opsluiting geldt voor het DNA-onderzoek op bevel van de onderzoeksrechter en zonder toestemming van de betrokkene.

Het mondeling bevel van de procureur des Konings om gegevens ontoegankelijk te maken in geval van uiterst dringende noodzakelijkheid is mogelijk voor bepaalde terroristische misdrijven (art. 39 bis \$ 6, zesde lid Sv.).

Een drempel die bij zware opsporingsbevoegdheden geregeld wordt gebruikt is de lijst van misdrijven die in art. goter $\$ 2-4$ Sv. wordt weergegeven. Het gaat om de misdrijven in het kader waarvan door de onderzoeksrechter een maatregel kan worden bevolen van onderscheppen, kennisnemen, doorzoeken en opnemen van niet voor het publiek toegankelijke communicatie of gegevens van een informaticasysteem of een deel ervan. De oorsprong van deze lijst van misdrijven kan worden gesitueerd bij de invoering in 1994 van de bevoegdheid voor de onderzoeksrechter om een telefoontap te bevelen. ${ }^{\text {II8 }}$ Toen werd besloten om voor de vormgeving van het proportionaliteitsbeginsel geen gebruik te maken van een bepaalde strafdrempel maar van een opsomming van ernstige misdrijven waarvoor deze maatregel geschikt en verantwoord geacht wordt. Deze lijst telt heden 45 misdrijven, waarbij ook de poging tot een van deze misdrijven in aanmerking komt alsmede de bendevorming met het oog op het plegen van een van de bedoelde misdrijven (art. goter $\$ 3$ en 4 Sv.).

Sedertdien werd deze lijst meermaals gebruikt om ook andere ernstige opsporingsdaden te normeren. Meestal werd dan aan de misdrijven uit deze lijst ook "enig ander misdrijf" toegevoegd "dat gepleegd werd in het kader van een criminele organisatie als bedoeld in artikel 324 bis van het Strafwetboek”. Dit criterium wordt aangewend bij het verlenen van het statuut van volledig anonieme getuige (art. 86bis $\$ 2$ Sv.), de bijzondere beschermingsmaatregelen ten behoeve van bedreigde getuigen (art. I04 $\$ 2$ Sv.), het bevriezen van banktegoeden (art. 46quater $\S 2$, b Sv.), ${ }^{119}$ de inkijkoperatie (art. 46quinquies $\S$ I, eerste lid en art. 89ter, eerste lid Sv.), de stelselmatige observatie met technische hulpmiddelen om zicht te verwerven in een woning (art. 56 bis, tweede lid Sv.), de infiltratie (art. 47octies $\S \mathrm{I}$, eerste lid Sv.) en het opsporen en lokaliseren van elektronische communicatie bij heterdaad door de procureur des Konings (art. 88bis § I, zesde lid Sv.).

II7 De maatregel is ook mogelijk voor wanbedrijven die niet strafbaar zijn met een straf van één jaar of meer maar dan kunnen de gegevens slechts betrekking hebben op een periode van zes maanden voorafgaand aan de beslissing.

II8 Wet van 30 juni I994 (BS 24 januari I995), thans volledig vervangen door de wet van 25 december 2016 (BS I7 januari 20I7).

II9 In dit geval wordt geen melding gemaakt van enig ander misdrijf in het kader van een criminele organisatie. 
Bij sommige van deze opsporingshandelingen wordt naast de betrokken drempel een bijkomende motivering vereist, die de bestaande verdenkingscriteria aanscherpt. Zo kan bij wijze van voorbeeld verwezen worden naar de in artikel goter Sv. bedoelde maatregel van onderscheppen van niet voor het publiek toegankelijke communicatie, waar bijkomend enerzijds aangegeven wordt dat de maatregel enkel mogelijk is indien de overige middelen van onderzoek niet volstaan om de waarheid aan de dag te brengen en anderzijds in de schriftelijke machtiging uitdrukkelijk de redenen dienen te worden aangegeven waarom de maatregel onontbeerlijk is om de waarheid aan de dag te brengen. Aldus wordt ook het subsidiariteitsbeginsel gestalte gegeven via een aangepaste motiveringsverplichting. Bij opsporingsmaatregelen die fundamentele rechten aantasten, is het in elk geval aangewezen om de subsidiariteitsvereiste kracht bij te zetten aan de hand van een strengere motiveringsverplichting.

De beginselen van proportionaliteit en subsidiariteit dienen in een nieuw wetboek van strafvordering als algemene beginselen in het wetboek ingeschreven te worden. Alle bevoegdheden, en derhalve ook de opsporings- en onderzoeksbevoegdheden van het Openbaar Ministerie en de onderzoeksrechter, dienen met inachtneming van deze beginselen te worden uitgeoefend. Waar de proportionaliteit kan worden uitgedrukt door middel van een bepaalde strafdrempel of de opsomming van misdrijven waarvoor deze bevoegdheid kan worden aangewend vereist de controle op de toepassing van de subsidiariteit steeds een rechterlijke tussenkomst. Deze controle kan slechts op een effectieve wijze geschieden indien de instantie die de betrokken maatregel heeft aangewend in zijn beslissing rekenschap aflegt van de wijze waarop deze eis werd nageleefd.

Terecht werd dan ook een gelijkaardige motiveringsverplichting opgenomen inzake de stelselmatige observatie (art. 47sexies $\$ 3,2^{\circ}$ Sv.) en de infiltratie (art. $470 c t i e s ~ \$ 3,2^{\circ} \mathrm{Sv}$.). Voor het afleveren van een huiszoekingsbevel wordt geen bijzondere motiveringsverplichting opgelegd wat de subsidiariteit van de maatregel betreft.

Op te merken valt dat de sanctionering van deze beginselen niet zeer duidelijk is. De tot voor kort bestaande nietigheidssanctie in artikel goter Sv. bij een onregelmatige motivering van het bevel tot telefoontap werd door de wet van 5 februari 2016 opgeheven zodat deze sanctie thans geregeld wordt door artikel 32 VTSV, dat de Antigoondoctrine inzake het onregelmatig verkregen bewijs regelt (zie hierna). Dit heeft tot gevolg dat in de praktijk een onregelmatige motivering wellicht zelden of nooit zal gesanctioneerd worden.

Het zal uiteindelijk de rechter toekomen te oordelen over de toepassing van het vereiste van subsidiariteit. Er bestaat geen algemeen aangevoelde nood om over te gaan tot een meer gestandaardiseerde indeling van de drempels vanaf wanneer een bepaalde onderzoeksmaatregel mag worden genomen. Hoewel zulks de overzichtelijkheid van het wetboek ten goede zou komen is het belangrijker de aanwending van deze bevoegdheden te onderwerpen aan de eisen van proportionaliteit en subsidiariteit en van de magistraten die het vooronderzoek leiden op dit punt in hun beslissing een deugdelijke motivering te vragen. 


\section{De verhouding tussen het vooronderzoek en het onderzoek ter terechtzitting}

\section{I Het ondervragingsrecht van getuigen (à charge)}

Er bestaat een vanzelfsprekend verband tussen het vooronderzoek en het onderzoek ter terechtzitting van het vonnisgerecht. De rechtspleging voor het vonnisgerecht is in essentie tegensprekelijk en zulks houdt in dat het onderzoek voor het vonnisgerecht verloopt in de vorm van een debat tussen de vervolgende en verdedigende partij. Hoewel de beklaagde hiertoe niet verplicht is, kan hij in deze procesfase zijn argumenten ontwikkelen en eventueel tegenbewijzen voorleggen. ${ }^{\text {120 }}$ Dit tegensprekelijk karakter houdt ook in dat elke partij niet alleen de mogelijkheid moet hebben om de elementen kenbaar te maken die nodig zijn om zijn eisen te staven maar ook om kennis te nemen van en te discussiëren over elk stuk en argument dat aan de rechter, met het oog op een beïnvloeding van zijn beslissing, wordt overgemaakt. ${ }^{\text {III }}$

Dit vereiste gaat verder dan louter het recht om alle gegevens van het schriftelijk dossier dat aan de rechter wordt voorgelegd en waarvan de partijen kennis hebben kunnen nemen voor de vonnisrechter te betwisten en te bediscussiëren. Dit recht houdt ook in dat een partij (en in het bijzonder de beklaagde) het recht dient te hebben om de herhaling van onderzoeksverrichtingen voor de vonnisrechter te bekomen indien daar reden toe is. De praktijk toont evenwel aan dat het onderzoek ter zitting van de vonnisrechter in grote mate herleid is tot een louter nazicht van de stukken van het strafdossier en dat de vonnisrechter in grote mate een 'verificatierechter' is geworden. ${ }^{122}$ Hoewel in nogal wat gevallen de mogelijkheid om de inhoud van het strafdossier tegen te spreken en te bediscussiëren kan volstaan is dit zeker niet in alle gevallen zo. Het onmiddellijkheidsbeginsel is dan ook sterk in de verdrukking gekomen.

Het belang van het onderzoek ter zitting van het vonnisgerecht dient overigens niet enkel in het perspectief van het recht van verdediging van de beklaagde te worden benaderd. Ook de oordeelsvorming van de rechter is gebaat bij een striktere naleving van het onmiddellijkheidsbeginsel voor de vonnisrechter. Zo is het duidelijk dat het verhoor van een getuige of deskundige ter zitting, ook al bevat het strafdossier reeds een verklaring van deze getuige of een verslag van de betrokken deskundige, een meerwaarde kan bieden, zeker in gevallen waarbij discussie bestaat over de draagwijdte van de betrokken verklaring of de inhoud van het deskundigenverslag.

Hoewel tegenspraak in het vooronderzoek nooit volledig de tegenspraak tijdens het onderzoek voor de vonnisrechter zal kunnen vervangen spreekt het voor zich

I2O C. VAN DEN WyngaERT, Strafrecht en strafprocesrecht in hoofdlijnen, Antwerpen, Maklu, 20I4, 592.

I2I Bijv. EHRM 20 juli 200I, Pelligrini/Italië; EHRM 8 april 2008, Kizil e.a./Turkije.

I22 G. KNIGGE, "Strafvordering in het geding" in Handelingen van de Nederlandse Juristenvereniging I994/I, Zwolle, Tjeenk Willink, I994, 69. 
dat een verhoogde tegenspraak tijdens het vooronderzoek ook de kwaliteit van het onderzoek ter terechtzitting zal verhogen.

Een bijzondere toepassing van deze beginselen kan men terugvinden bij het ondervragingsrecht van getuigen ter terechtzitting van het vonnisgerecht.

Gelet op het niet tegensprekelijk karakter van het vooronderzoek vindt het verhoor van een getuige in die procesfase plaats op een niet tegensprekelijke wijze. In beginsel heeft de verdachte tijdens het vooronderzoek niet de gelegenheid om een getuige die een belastende verklaring aflegt (en dus als een getuige à charge in de zin van artikel 6.3.d EVRM moet worden beschouwd) zelf te ondervragen. Het EHRM aanvaardt dat de verdediging het recht heeft met de getuigen ten laste te worden geconfronteerd. ${ }^{123}$ Waar een dergelijke confrontatie in beginsel in een openbare terechtzitting dient plaats te vinden - het getuigenverhoor in het vooronderzoek is geen alternatief voor de getuigenis ter zitting - wordt niet uitgesloten dat een dergelijke confrontatie in bepaalde gevallen ook in het vooronderzoek wordt gerealiseerd. Deze benadering spoort met het gegeven dat artikel 6.3.d EVRM als een bijzondere verschijningsvorm van het recht op een eerlijk proces in de zin van artikel 6.I EVRM wordt beschouwd en de vraag of een beklaagde een eerlijk proces heeft genoten dient te worden beantwoord op basis van het procesverloop in zijn geheel genomen.

Het EHRM heeft reeds eerder geoordeeld dat de rechter gebruik mag maken van de schriftelijke verklaringen van een getuige die niet werd geconfronteerd met de verdachte voor zover deze verklaringen slechts dienen als steunbewijs. ${ }^{24}$ Een probleem ontstaat evenwel wanneer de betrokken getuigenverklaring het enige bewijs of het doorslaggevende bewijs uitmaakt en wanneer de beklaagde voor de vonnisrechter om de oproeping van de getuige à charge verzoekt.

De laatste jaren heeft de rechtspraak van het EHRM zich met betrekking tot de beoordeling door de rechter van een dergelijk van de beklaagde uitgaand verzoek strenger opgesteld.

In de zaken Al-Khawaja en Schatschaschwili heeft het EHRM in het licht van de artikelen 6.I en 6.3.d EVRM de principes uiteengezet met betrekking tot de afwezigheid van getuigen ter terechtzitting en in het bijzonder de vraag in welke mate gebruik mag worden gemaakt van de verklaringen van een getuige die niet verschenen is en tijdens het proces niet werd ondervraagd. Hoewel er niet automatisch een schending van artikel 6 EVRM voorligt indien de rechter een dergelijke getuigenverklaring gebruikt, dient de feitenrechter bij de vraag of van zo'n verkla-

I23 Bijv. EHRM 20 december 200I, P.S./Duitsland § 2I: "All the evidence must normally be produced at a public hearing, in the presence of the accused, with a view to adversarial argument. There are exceptions to this principle, but they must not infringe the rights of the defence. As a general rule, the accused must be given an adequate and proper opportunity to challenge and question a witness against him, either when he makes his statement or at a later stage (see the Van Mechelen and Others judgment cited above, p. 7II, § 5 I and the Lüdi v. Switzerland judgment of I5 June I992, Series A no. 238, p. 2I, § 49)."

I24 EHRM 26 april I99I, Asch/Oostenrijk, § 30. 
ring gebruik mag worden gemaakt drie vragen te stellen: (I) Zijn er ernstige redenen van feitelijke of juridische aard die de afwezigheid van de getuige ter zitting rechtvaardigen?, (2) Is de belastende verklaring het enige of doorslaggevende element waarop de schuldigverklaring steunt, waarbij onder doorslaggevend wordt verstaan het bewijs dat dermate belangrijk is dat het aannemelijk is dat het het resultaat van de zaak heeft bepaald? en (3) Zijn er voldoende procedurele waarborgen voor de verdediging om de moeilijkheden die als gevolg van het gebruik van deze verklaring voor de verdediging ontstaan te compenseren en aldus het eerlijk karakter van het proces in zijn geheel te verzekeren? ${ }^{125}$ Hierbij valt te noteren dat, indien niet duidelijk uit te maken is of de betrokken verklaring het determinerende element is geweest, dezelfde eisen gesteld worden indien de verklaring een zeker gewicht heeft en dit bewijselement moeilijkheden heeft veroorzaakt voor de verdediging. ${ }^{126}$ België werd op dezelfde grondslag door het Mensenrechtenhof veroordeeld in de zaak Riahi. ${ }^{127}$ De drie aangegeven criteria dienen in die volgorde te worden onderzocht.

Aldus dient te worden onderzocht of er gegronde redenen bestaan voor de afwezigheid van de getuige à charge ter terechtzitting. Hoewel de afwezigheid van dergelijke redenen op zichzelf niet leidt tot de schending van het eerlijk proces is zulks wel een belangrijk element dat het oordeel van de rechter doet neigen naar een vaststelling van de schending van de artikelen 6.I en 6.3.d EVRM. ${ }^{\mathrm{I} 2}$ Anderzijds betekent dit wel dat de afwezigheid van gegronde redenen in bepaalde gevallen nog kan worden 'geneutraliseerd' als gevolg van het onderzoek van de volgende twee vragen en bijvoorbeeld door de vaststelling dat de verklaring niet determinerend was en er voldoende compenserende elementen aanwezig waren. ${ }^{129}$

Zonder op dit punt in detail in te gaan kan worden aangestipt dat het EHRM wel bepaalde omstandigheden aanvaardt als een gegronde reden voor de afwezigheid van de getuige, zoals het feit dat de getuige onverwacht verdwenen is en dus onvindbaar ${ }^{130}$ of als de getuige overleden is. Het EHRM heeft de aanwezigheid van gegronde redenen ook aangenomen in het geval van het verhoor van politieambtenaren die geïnfiltreerd waren. ${ }^{\mathrm{II}}$

De Belgische rechtspraak was tot voor kort vrij soepel met betrekking tot de beoordeling door de vonnisrechter van een verzoek van de beklaagde tot het verhoren van een getuige à charge ter zitting van het vonnisgerecht. De vaste rechtspraak van het Hof van Cassatie houdt in dat artikel 6.3.d EVRM geen absoluut

I25 EHRM I5 december 20II, Al-Khawaja en Tahery/Verenigd Koninkrijk, RW 20I3-I4, 835; EHRM I5 december 20I5, Schatschachwili/Duitsland, T. Strafr. 20I6, I96.

I26 Voor een recente toepassing: EHRM 27 juni 20I7, Valdhuter/Roemenië; EHRM 23 juni 20I6, Ben Moumen/Italië.

I27 EHRM I4 juni 20I6, Riahi/België, T. Strafr. 20I6, 347-354, met noot C. VAN DE HeYNING, "Riahi, of de kroniek van een aangekondigde veroordeling".

I28 EHRM I4 juni 20I6, Riahi/België, §3I.

I29 Wat bijvoorbeeld het geval was in de zaak Moumen (EHRM 23 juni 20r6, Ben Moumen/Italië).

I30 Alhoewel van de nationale staten wel verwacht wordt dat alle redelijke inspanningen worden ondernomen om de betrokken getuige aan te treffen (EHRM 23 juni 20r6, Ben Moumen/Italië).

I3I EHRM 23 mei 20I7, Van Wesenbeeck/België, §IOO-IOI. Voor een toepassing waar de infiltranten als anonieme getuigen gehoord waren: EHRM I2 januari 2017, Batek en anderen/Tsjechië. 
recht inhoudt om getuigen op te roepen en de rechter oordeelt of het verhoor noodzakelijk is voor het achterhalen van de waarheid zolang de rechten van verdediging zijn gerespecteerd. ${ }^{\mathrm{I} 2}$ De veelvuldig gehanteerde overweging dat het recht van verdediging wordt geëerbiedigd indien de beklaagde werd geconfronteerd met de belastende verklaringen en hierover op de terechtzitting van de vonnisrechter alle nodige tegenspraak heeft kunnen voeren zal in de toekomst nochtans niet meer volstaan. Het is immers logisch dat de loutere mogelijkheid om op de zitting de in het vooronderzoek afgelegde getuigenverklaring à charge te kunnen betwisten niet op dezelfde voet gesteld kan worden met de ondervraging van die getuige ter zitting van het vonnisgerecht. SCHUERMANS ziet hierin een bijkomend argument voor de invoering van een geïntegreerd vooronderzoek, aangezien het verhoor toch moet worden overgedaan door de bodemrechter, ongeacht of dat in het vooronderzoek is gebeurd door politie, het $\mathrm{OM}$ of de onderzoeksrechter. ${ }^{\mathrm{I}}{ }^{3}$

De door het EHRM voorgeschreven toets werd door het Hof van Cassatie reeds gedaan in een arrest van I4 maart 20I7. ${ }^{\mathrm{I} 34}$ Geoordeeld werd ook dat deze drieledige toets niet dient te worden verricht bij bijvoorbeeld de vraag tot het horen van deskundigen wanneer de deskundigenverslagen geen betrekking hebben op de schuldigverklaring maar enkel op de straftoemeting. ${ }^{135}$

De Straatsburgse rechtspraak vereist derhalve in de eerste plaats een koerswijziging van de zijde van de vonnisrechters die over een dergelijk verzoek tot getuigenverhoor dienen te oordelen. Anderzijds - en hoewel het getuigenverhoor tijdens het vooronderzoek een verhoor voor de vonnisrechter niet overbodig maakt - kunnen procedurele mogelijkheden om een getuige à charge tijdens het vooronderzoek te ondervragen eventueel compenserende factoren uitmaken die tot gevolg hebben dat het proces toch zijn eerlijk karakter behoudt.

In dit verband kan gewezen worden op het recht om bijkomende onderzoeksdaden te vorderen overeenkomstig artikel 6rquinquies Sv. Niets belet dat de onderzoeksrechter in het kader van een dergelijk verzoek zou bevelen om de getuige à charge te ondervragen in aanwezigheid van de verdachte en zijn advocaat waarbij de gelegenheid wordt gegeven om vragen te stellen. Dit verhoor zou door de onderzoeksrechter zelf geleid kunnen worden of zou door de politie in opdracht van de onderzoeksrechter uitgevoerd kunnen worden.

In een eventueel toekomstig geïntegreerd vooronderzoek onder leiding van het Openbaar Ministerie zou dergelijk tegensprekelijk verhoor door de procureur ambtshalve of op vraag van de verdediging kunnen worden georganiseerd.

Indien het verkieslijker geacht wordt dat de getuige onder eed zou worden ondervraagd zal zulks vanzelfsprekend door de onderzoeksrechter dienen te gebeuren.

I32 Cass. I4 oktober 20I4, P.I4.0507.N; Cass. I5 september 2015, P.I4.056r.N; Cass. 22 september 2015, P.I4.OII8.N.

I33 F. SCHUERMANS, "EHRM verplicht oproeping te zitting van getuige à charge", Juristenkrant, 20I6, afl. 337, I3.

I34 Cass. I4 maart 20I7, P.I6.II52.N.

I35 Cass. I8 april 2017, P.I6.I292.N. 
In het licht van een eventueel compenserende werking van dergelijk verhoor voor de afwezigheid van de getuige voor het vonnisgerecht zal dit veelal aangewezen zijn aangezien de getuige, indien hij zou gehoord worden voor het vonnisgerecht, de eed zal moeten afleggen. Gelet op de rechtspraak van het EHRM zal de compenserende werking van een getuigenverhoor tijdens het vooronderzoek evenwel nog steeds in hoge mate afhankelijk zijn van het antwoord op de vraag of er gerechtvaardigde motieven zijn voor de afwezigheid van de getuige ter zitting en of de getuigenverklaring al dan niet het enige of doorslaggevende element in de bewijsconstructie is. De reeds sedert enige tijd aan de gang zijnde beweging "naar voren" in het strafprocesrecht wordt dan ook door deze rechtspraak, in elk geval wat een vraag tot getuigenverhoor betreft, ernstig afgeremd.

\subsection{Sanctionering van vormverzuimen}

\subsubsection{Verleden en heden}

Zoals Nederland heeft ook België sedert enkele jaren een wettelijke regeling inzake de bewijsuitsluiting of de sanctionering van vormverzuimen bij de bewijsvergaring. Artikel $32 \mathrm{VTSV}^{136}$ bepaalt thans dat tot nietigheid van onregelmatig verkregen bewijselement enkel wordt besloten indien (I) de naleving van de betrokken vormvoorwaarden wordt voorgeschreven op straffe van nietigheid of (2) de begane onrechtmatigheid de betrouwbaarheid van het bewijs heeft aangetast of (3) het gebruik van het bewijs in strijd is met het recht op een eerlijk proces.

Deze wet is in grote mate zoniet uitsluitend tot stand gekomen onder invloed van een wijziging in de rechtspraak die is ingezet met het zogenoemde Antigoonarrest van het Hof van Cassatie van I4 oktober 2003. Het betrokken arrest heeft tot vele discussies en commentaren aanleiding gegeven. ${ }^{137}$

I36 Zoals ingevoerd door de wet van 24 oktober 2013 (BS I2 november 2013).

I37 Cass. I4 oktober 2003, Arr.Cass. 2003, nr. 499, conclusie advocaat-generaal DE SwAEF, RW 2003-2004, conclusie advocaat-generaal M. DE SwAEF, T. Strafr. 2004, I29-I43, noot P. TRAEST, "Onrechtmatig verkregen doch bruikbaar bewijs: het Hof van Cassatie zet de bakens uit", RABG 2004, 333-357, noot F. SCHUERMANS, "De nieuwe cassatierechtspraak inzake de sanctionering van het on rechtmatig verkregen bewijs: doorbraak of bres?”, RCJB 2004, 405-438, noot F. KUTY, "La règle de l'exclusion de la preuve illégale ou irrégulière: de la précision au bouleversement", Vigiles 2004/I, I6-27, noot F. SCHUERMANS, "Ook de onrechtmatige voertuigzoeking kan dienen als geldig bewijs: het cassatiearrest van I4 oktober 2003".

In verband met de evolutie van de rechtspraak inzake de bewijsuitsluiting raadplege men tevens de volgende bijdragen: M.A. BEERNAERT, "La fin du régime d'exclusion systématique des preuves illicitement receuillies par les organes chargés de l'enquête et des poursuites”, JLMB 2005, IO94-IIO9; F. DERUYCK, "Wat krom is wordt recht. Over de bruikbaarheid van onrechtmatig verkregen bewijs”, Postuniversitaire lessencyclus Willy Delva, 2005-2006, Strafrecht en strafprocesrecht, Mechelen, Kluwer, 2006, 20I-23I; S. DE DECKER, "Onrechtmatig verkregen bewijs in strafzaken: privaat domein?", Panopticon 2007.2, 8-I8; B. DE SMET, "Stromingen in het stelsel van nietigheden. Nieuwe criteria voor de uitsluiting van onrechtmatig verkregen bewijs", T. Strafr. 2005, 248; S. BERNEMAN, "Sanctionering van onrechtmatig verkregen bewijsmateriaal: een inleiding tot het Antigoonarrest van I4 oktober 2003", T. Strafr. 2004, 2-39; S. BERNEMAN, "Van relativering naar rationalisering van de bewijsuitsluitingsregel", T. Strafr. 2005, 489-507; J. DE CODT, "Preuve pénale et nullités", Rev. dr. pén. 2009, 634-666 A. MASSET, "Les preuves illégales et irrégulières en matière pénale: 8 ans d'application du test Antigone" in X (eds.), Bewijs in strafzaken/la preuve en droit pénal, Brugge, Die Keure, 20II, 3-35; F. SCHUERMANs, "Antigoon geen vrijgeleide voor onbehoorlijk politieoptreden: trekt cassatie de teugels aan ?”, noot onder Cass. 
Deze wending in de rechtspraak maakte een einde aan een lange periode van toepassing van een radicale uitsluitingsregel die in 1923 in het Belgische strafprocesrecht zijn intrede had gedaan. ${ }^{13^{8}}$ Krachtens deze regel wordt het niet toegelaten een persoon te veroordelen op grond van bewijsmateriaal dat op een onrechtmatige manier is verkregen.

Met het arrest van het Hof van Cassatie van I3 mei 1986 werd duidelijk dat deze uitsluitingsregel drie soorten onrechtmatig verkregen bewijs betreft: bewijs verkregen door een met de materiële wet strijdige daad, verkregen door middel van een daad strijdig met de regelen van formeel strafprocesrecht en verkregen door een daad strijdig met de algemene rechtsbeginselen. ${ }^{139}$ Ook het bewijs verkregen door een handeling die niet verenigbaar is met de grondregelen van de strafrechtspleging en meer bepaald met de eerbiediging van het recht van verdediging, waartoe het zwijgrecht behoort, valt hieronder. ${ }^{140}$ In het eerder vermelde arrest van 13 mei 1986 werd voor het eerst ook een onderscheid gemaakt tussen onwettigheid en onrechtmatigheid. Dit laatste begrip kan worden gezien als de waardigheid van het gerecht, met de daaraan verbonden vereiste van loyauteit van het bewijs of nog de vereiste van behoorlijkheid in de opsporing en de bewijsvoering, zeker indien het gaat om handelingen die uitgaan van overheidsagenten of privépersonen die in opdracht van of in samenspraak met de overheid handelen. ${ }^{\text {III }}$ De notie 'onrechtmatigheid' is derhalve een stuk ruimer dan een loutere onwettigheid.

23 september 2008, T. Strafr. 2009, I52-I58; D. DE WOLF, "Nieuwe wending in de rechtspraak betreffende de sanctie bij onrechtmatig verkregen bewijs: het cassatiearrest van I4 oktober 2003”, RW 2003-2004, I235-I239; F. KUTY, "Le droit de la preuve au regard de la jurisprudence récente de la Cour de cassation”, in Questions d'actualité de droit pénal et de procédure pénale, Brussel, Bruylant, 2005, 53-I07; F. KUTY, " La règle de l'exclusion de la preuve illégale ou irrégulière: de la précision au bouleversement", RCJB 2004, 408-438; P. TRAEST, "Het bewijs in strafzaken na Antigoon" in Orde van advocaten Kortrijk (ed.), Recente ontwikkelingen in het strafrecht, Gent, Larcier, 2008, I09-I37; K. VAN DONINCK, "Onrechtmatig verkregen bewijs in strafzaken: van dogmatisme naar pragmatisme” in R. BOYDENS \& R. DE BAERDEMAKER (ed.), Justitie: vraagstukken en perspectieven voor morgen, Brugge, Die Keure, 20I3, I-I4; A. MASSET, "Jurisprudence Antigone" in R. BOYDENS \& R. DE BAERDEMAKER (ed.), Justitie: vraagstukken en perspectieven voor morgen, Brugge, Die Keure, 2013, I5-30.

I38 Cass. I2 maart 1923, Pas. I923, I, 233; Cass. Io december 1923, Pas.1924, I, 67, met conclusie van P. LECLERCQ. In beide gevallen ging het om een onwettig bevonden huiszoeking. Voor een uitgebreider overzicht van de voorgeschiedenis van het Antigoon-arrest van het Hof van Cassatie raadplege men onder meer P. TRAEST, "Het bewijs in strafzaken na Antigoon" in Orde van Advocaten Kortrijk (ed.), Recente ontwikkelingen in het strafrecht, Gent, Larcier, 2008, I09-I38. Terecht werd opgemerkt (S. VAN OVERBEKE, "Het recht van verdediging: de verdediging van het onrecht?" in De wet voorbij. Liber amicorum Luc Huybrechts, Antwerpen, Intersentia, 2010, 537-57I, voetnoot I9) dat de beide arresten uit 1923 wellicht steunen op een eerder arrest van 20 maart igr6 (Pas. I9I5-I9i6, I, 305, conclusie advocaat-generaal PHOLIEN).

I39 Cass. 13 mei I986, Arr.Cass. 1985-86, nr. 558, conclusie advocaat-generaal Du JARDIN.

I40 Cass. I3 januari 1999, Arr.Cass. I999, nr. I5, met strijdige conclusie advocaat-generaal DE RIEMAECKER.

I4I J. DU JARDIN, conclusie voor Cass. 4 januari I994, Arr.Cass. I994, nr. I. 
In twee arresten van respectievelijk $\mathrm{I} 7$ januari $199 \mathrm{O}^{\mathrm{I42}}$ en $\mathrm{I} 7$ april $\mathrm{I} 99 \mathrm{I}^{\mathrm{I} 43}$ werden vervolgens de krijtlijnen getrokken voor een eerste relativering van de uitsluitingsregel gebaseerd op de hoedanigheid van de verkrijger van het bewijs enerzijds en zijn bedoeling anderzijds.

Het Hof van Cassatie oordeelde in beide gevallen dat uit het enkele feit dat de stukken bedrieglijk van de eigenaar werden weggenomen niet noodzakelijk volgt dat de overlegging ervan in rechte onrechtmatig is. Vervolgens stelt het Hof vast dat (I) de met het onderzoek belaste personen en de aangever geen enkele onrechtmatige daad hebben gepleegd om in het bezit te komen van dat stuk en (2) er geen verband bestaat tussen de diefstal van de litigieuze stukken en de overhandiging ervan aan de met het onderzoek belaste personen.

In twee latere arresten van 4 januari $1994^{\mathrm{I} 44}$ en 9 december $1997^{\mathrm{I} 45}$ wordt deze regel - zij het onrechtstreeks ${ }^{\mathrm{I} 46}$ - opnieuw toegepast. De rechter kan ook weigeren een bewijs te weren dat door een ongeoorloofde daad is verkregen wanneer de derde, via wie dat bewijs bij de speurders terecht is gekomen, zelf geen uitstaans heeft met enige onrechtmatige handeling. ${ }^{\mathrm{I} 77}$ De relativering van de uitsluitingsregel

I42 Cass. I7 januari I99o, Arr.Cass. I989-90, nr. 3I0, RW I990-I99I, 463-464, noot HuybRECHTS. Dit arrest had betrekking op een aantekenboekje dat de 'zwarte' boekhouding van de beklaagde bevatte en gestolen werd door een persoon die oorspronkelijk de betrokkene hiermee wilde chanteren doch vervolgens zijn plannen wijzigde en dit boekje overhandigde aan een andere persoon, die het ten slotte aan de politiediensten overmaakte. Op basis van dit bewijselement werd de beklaagde vervolgens veroordeeld.

I43 Cass. I7 april I99I, Rev.dr.pén. I992, 94-Io9, noot DE VALCKENEER, RW, I99I-92, 403, noot VANDEPLAS. Dit arrest had betrekking op het gebruik in een strafproces van gegevens die ten nadele van de beklaagde waren gestolen door zijn echtgenote, met wie hij in een echtscheidingsprocedure was gewikkeld. Bij een huiszoeking ingevolge de door de beklaagde wegens de diefstal ingediende klacht werden deze stukken aangetroffen en werden zij vervolgens gebruikt om de beklaagde te veroordelen. Over dit arrest en het in de vorige noot vermelde arrest zie eveneens: F. Hutsebaut, "Private opsporing en de bewijsvoering voor de strafrechter" in L. VAN OUTRIVE, T. DeCORTE \& W. VAN LAETHEM (ed.), Private bewaking en opsporing en de grondrechten van de mens, Politeia, I995, 209 e.v.; J. DE CODT, "Les nullités de l'instruction préparatoire et le droit de la preuve. Tendances récentes”, Rev.dr.pén. 2000, 54-57; P. TRAEST, "De rol van de particulier in het bewijsrecht in strafzaken" in Liber Amicorum Jean du Jardin, Antwerpen, Kluwer, 200I, 66-7I.

I44 Arr.Cass. I994, nr. I, RW I994-95, I85-I88, conclusie advocaat-generaal du Jardin, noot F. D'HONT, R.Cass. I994, 72-75, noot P. TRAEST. Het gaat hier om het zgn. 'nachtwakersarrest', waarbij een nachtwaker nota had genomen van documenten waartoe hij toegang had en die betrekking hadden op de zwarte boekhouding van zijn werkgever. Geoordeeld werd dat dergelijk gedrag geen misdrijf of enige andere onrechtmatige verkrijging opleverde. Men raadplege ook J. MEsSINNE, "Développements récents de la jurisprudence en matière de preuve pénale" in Liber amicorum José Vanderveeren, Brussel, Bruylant, I997, 99-гоo.

I45 Arr.Cass. I997, nr. 542. De aangever was op een toevallige manier in het bezit gekomen van stukken die hij eerst een tijd had verborgen en nadien aan een derde had overhandigd. Vervolgens kwamen deze stukken in handen van de vervolgende instanties.

I46 In deze beide arresten werd immers geoordeeld dat de particulier zich niet schuldig gemaakt had aan enig misdrijf of enige andere onrechtmatigheid.

I47 Cass. I8 mei 20II, AR P.Io.2049.F in het kader van een vervolging tegen een politiek mandataris op grond van documenten uit het archief van de gemeente, geraadpleegd door een gemeenteraadslid in strijd met het reglement van inwendige orde over de raadpleging van de archieven (A. MASSET, "Les preuves illégales et irrégulières en matière pénale: 8 ans d'application du test Antigone" in X (eds.), Bewijs in strafzaken/la preuve en droit pénal, Brugge, Die Keure, 20II, 30-3I). 
indien een particulier ten grondslag ligt van de onrechtmatige bewijsvoering is nochtans voor ernstige kritiek vatbaar. ${ }^{148}$

Een tweede fase van relativering van de sanctie van uitsluiting van onrechtmatig verkregen bewijs heeft betrekking op het onderscheid tussen een aangifte en een bewijs. De op een onregelmatigheid berustende aangifte hoeft immers niet op dezelfde wijze te worden benaderd als het onrechtmatig verkregen bewijs. De vraag is immers of het mogelijk is gebleken op een rechtmatige manier bewijs te verzamelen van het op deze manier aan de overheid ter kennis gebrachte feit.

In het arrest van het Hof van Cassatie van 30 mei $1995^{149}$ oordeelde het Hof van Cassatie dat het bewijs van een misdrijf niet hetzelfde is als de bekendmaking van een misdrijf en dat een bekendmaking niet voor onbestaande kan gehouden worden. Het Hof overweegt verder: "Overwegende dat in geval van bekendmaking van een misdrijf het aan het bevoegde openbaar ministerie staat te oordelen welk gevolg hieraan wordt gegeven en of het mogelijk lijkt om er regelmatig bewijs van in te zamelen. Dat de omstandigheid dat de aangever van het misdrijf dit ingevolge een onwettigheid heeft vernomen, geen afbreuk doet aan de rechtmatigheid van het bewijs, dat zelf zonder enige onwettigheid naderhand werd verkregen."

De Antigoonrechtspraak werd vrij snel in een wettelijke regeling omgezet waar het gaat om de uitsluiting van onrechtmatig verkregen bewijs in een internationale context. ${ }^{150}$

Sedert de vermelde wettelijke regeling uit 2013 zijn er dus slechts drie gevallen waarin tot onrechtmatigheid en dus uitsluiting van het bewijs kan worden besloten.

De eerste situatie is voor de praktijk weinig relevant. Er zijn immers in de Belgische wetgeving zeer weinig vormvoorschriften die op straffe van nietigheid zijn voorgeschreven. In de gevallen waarin dit wel het geval is (bijv. artikel 86bis $§ 4$ en 86ter $\S 5$ in verband met de anonieme getuigenis) kan men zich bovendien de

I48 P. TRAEST, "De rol van de particulier in het bewijsrecht in strafzaken" in Liber Amicorum Jean du Jardin, Antwerpen, Kluwer, 200I, 66-7I; P. TRAEST, "Het bewijs in strafzaken na Antigoon" in Orde van Advocaten te Kortrijk (ed.), Recente ontwikkelingen in het strafrecht, Gent, Larcier, 20o8, II2; F. Hutsebaut, "Private opsporing en de bewijsvoering voor de strafrechter" in L. VAN Outrive, T. Decorte \& W. VAN LAETHEM (ed.), Private bewaking en opsporing en de grondrechten van de mens, Politeia, I995, 2I4; J. DU JARDIN, conclusie voor Cass. 4 januari 1994, Arr.Cass. I994, nr. I.

I49 Cass. 30 mei I995, Arr.Cass. I995, nr. 267, conclusie advocaat-generaal Goeminne, J.L.M.B. I998, 488, noot F. KuTY, R.Cass. I996, I42 e.v., noot P. TRAEST, Rev. dr. pén. I996, II8. In deze zaak was een informatieonderzoek gestart als gevolg van op aanwending van afluistertechnieken steunende inlichtingen die door de Franse rijkswacht waren medegedeeld. Deze technieken waren toegepast op een ogenblik dat Frankrijk nog niet beschikte over wetgeving die het afluisteren van telefoongesprekken overeenkomstig art. 8 EVRM toeliet. De feitenrechters hadden geoordeeld dat het in België gevoerde onderzoek niet los kon worden gezien van het in Frankrijk gevoerde onderzoek, dat het noodzakelijke uitgangspunt vormde.

I50 Art. I3 van de wet van 9 december 2004 betreffende de internationale politiële verstrekking van gegevens van persoonlijke aard en informatie met gerechtelijke finaliteit, de wederzijdse internationale rechtshulp in strafzaken en tot wijziging van artikel goter van het Wetboek van Strafvordering (BS 24 december 2004). 
vraag stellen of het steeds gaat om vormvoorschriften die dermate essentieel zijn dat een dergelijke sanctie dient te gelden. Anderzijds is er van nietigheid geen sprake in de artikelen betreffende de bijzondere opsporingsmethoden, de huiszoeking, het DNA-onderzoek e.d.m. Deze toestand is het logische gevolg van het feit dat de wetgever in het verleden bij het uitwerken van een wettelijke regeling omtrent het bewijs, gelet op de tot 2003 geldende absolute uitsluitingsregel, zich nooit de vraag heeft hoeven stellen of het betrokken vormvoorschrift dermate essentieel was dat aan de miskenning ervan een nietigheidssanctie diende te worden gekoppeld. De miskenning van verdragsrechtelijk of grondwettelijk gewaarborgde grondrechten heeft evenmin tot gevolg dat het bewijs altijd ontoelaatbaar is. ${ }^{15^{1}}$

De tweede uitsluitingsgrond heeft betrekking op de gevallen waarbij de onrechtmatigheid of de onregelmatigheid bij de bewijsgaring wel een onmiddellijke impact heeft op de betrouwbaarheid van het bewijs. De toegevoegde waarde van dit criterium is gering aangezien dit vooral aan de orde is in de gevallen waarbij de betrokken bewijsmethode wettelijk geregeld is en dat komt weinig voor. De toepassing van dit criterium is in de praktijk dan ook verwaarloosbaar. ${ }^{152}$ Overigens kan worden opgemerkt dat de rechter onbetrouwbaar bewijs nooit als basis voor zijn uitspraak zal gebruiken, wat ook de oorzaak van deze onbetrouwbaarheid is.

Het derde criterium is logischerwijze dan ook het criterium dat in de praktijk het meest tot discussie aanleiding heeft gegeven. Deze derde uitsluitingsgrond verwijst rechtsreeks naar artikel 6 EVRM en de notie van het eerlijk proces. Het Hof van Cassatie heeft dit uitsluitingscriterium in meerdere arresten sedert 2003 nader ingevuld. Het uitgangspunt blijft dat het eerlijk karakter van het proces beoordeeld moet worden rekening houdende met het proces in zijn geheel beschouwd. Dit principe spoort met de rechtspraak van het EHRM waaruit ook blijkt dat artikel 6 EVRM op zich geen bewijsuitsluiting oplegt en het aan de nationale overheden toekomt regels uit te werken met betrekking tot de uitsluiting van onrechtmatig verkregen bewijs of enige andere sanctie. De door het Hof van Cassatie uitgewerkte subcriteria zijn niet cumulatief toe te passen. Het gaat enkel om criteria waar de rechter rekening mee kan houden maar zonder dat hij verplicht zou zijn om in elke concrete casus al deze criteria te overlopen en te onderzoeken. Hieruit blijkt dus al dat de feitenrechter een bijzonder grote vrijheid heeft bij de beoordeling van het lot van het onrechtmatig verkregen bewijs.

De subcriteria die werden uitgewerkt zijn de volgende: ${ }^{153}$

I5I Cass. I6 november 2004, T. Strafr. 2005, 285, noot R. VERSTRAETEN en S. DE DECKER, "Antigoon sluit de achterpoort maar opent een raam", RABG 2005, 504, concl. advocaat-generaal P. DUINSLAEGER. Ook de omstandigheid dat de niet-nageleefde bepaling de bescherming van het privéleven beoogt, doet niets af aan de regel dat bewijs enkel kan worden uitgesloten in de gevallen bepaald in art. 32 VTSV.

I52 J. MEESE, "Het bewijs in strafzaken" in P. TAELMAN (ed.), Efficiënt procederen voor een goede rechtsbedeling, XLIste Postuniversitaire cyclus Willy Delva, Mechelen, Kluwer, 2016, 525.

I53 J. MEESE, "Het bewijs in strafzaken" in P. TAELMAN (ed.), Efficiënt procederen voor een goede rechtsbedeling, XLIste Postuniversitaire cyclus Willy Delva, Mechelen, Kluwer, 20I6, 527-53I. 
- De vraag of de overheid die met de opsporing, het onderzoek en de vervolging van misdrijven is belast de on rechtmatigheid al dan niet opzettelijk heeft begaan. Zelfs een opzettelijk begane onrechtmatigheid hoeft niet tot bewijsuitsluiting te leiden terwijl een onverschoonbare fout van de opsporingsambtenaren (die dus niet opzettelijk is) wel kan leiden tot bewijsuitsluiting.

- De verhouding tussen de ernst van de onregelmatigheid en de ernst van het misdrijf. Naarmate de ernst van de onderzochte feiten toeneemt, mag de rechter dus meer door de vingers zien. Dit subcriterium is bevreemdend aangezien het EHRM net de omgekeerde redenering volgt. ${ }^{54}$ Op te merken valt dat dit subcriterium in de praktijk, al dan niet in samenhang met andere subcriteria, geregeld wordt aangewend om onrechtmatig verkregen bewijs niet uit te sluiten.

- De omstandigheid dat het onrechtmatig verkregen bewijs alleen een materieel element van het misdrijf betreft. Dit criterium wordt in de praktijk weinig toegepast.

- De omstandigheid dat de onrechtmatigheid geen weerslag heeft gehad op het recht of de vrijheid die de norm beoogt te beschermen. ${ }^{155}$ Dit subcriterium vertoont een zeer grote gelijkenis met de normdoeltheorie of de zogenoemde Schutznorm.

- De omstandigheid dat het miskende vormvoorschrift een puur formeel karakter heeft. Algemeen wordt evenwel aangenomen dat dit vijfde subcriterium aan de materie weinig of niets toevoegt.

De wettelijke verankering van de Antigoonrechtspraak in artikel 32 VTSV heeft tot gevolg gehad dat er geen ruimte meer bestaat voor de aanneming van andere hoofdcriteria. Zo heeft het Hof van Cassatie in een arrest van 24 april 2013 geoordeeld dat bewijsmateriaal niet mag worden aangewend indien dit werd verkregen in strijd met substantiële voorschriften die raken aan de organisatie van hoven en rechtbanken. ${ }^{156}$ Dit was voor de invoering van artikel 32 VTSV. In dezelfde zaak werd vervolgens op 23 september 2015 geoordeeld dat de nietigheid van een onregelmatig verkregen bewijselement, bedoeld in artikel 32 Voorafgaande Titel Wetboek van Strafvordering, dat betrekking heeft op de eerbiediging van de op straffe van nietigheid voorgeschreven vormvoorschriften, geen miskenning inhoudt van een substantiële regel betreffende de organisatie van de hoven en rechtbanken en werd vervolgens aangenomen dat de betrokken vergissing door de opsporingsambtenaren verschoonbaar was. ${ }^{157}$ Hierdoor wordt het vermoeden versterkt dat

I54 Naarmate de ernst van de feiten en dus het risico op een zware bestraffing van de beklaagde toeneemt moet de strafprocedure meer waarborgen inhouden (zie bijv. EHRM 27 november 2008, Salduz/Turkije, § 54).

I55 Zie in dit verband het zgn. winkelkassa-arrest: Cass. 2 maart 2005, Arr. Cass. 2005, nr. I30, JLMB 2005, IO86-IIO9, met noot M.A. BEERNAERT.

I56 Cass. 24 april 2013, RW 2013-I4, I620, noot B. DE SMET.

I57 Cass. 23 september 20I5, RDPC 20I6, 72-89, noot M.A. BEERNAERT. De regel vervat in art. 32 VTSV geldt voor alle on regelmatigheden, ongeacht of zij een inbreuk inhouden op een bepaling van openbare orde dan wel betrekking hebben op een regel van rechterlijke organisatie (Cass. I9 mei 20I5, T. Strafr. 20I5, 26I, noot T. DECAIGNY). 
ook deze onregelmatigheden enkel tot uitsluiting kunnen leiden indien zij onder de toepassing van artikel 32 VTSV kunnen worden gebracht. ${ }^{158}$

Ook de omstandigheid dat het miskende voorschrift ertoe strekt de intrinsieke kwaliteit van het bewijs te waarborgen blijkt na de invoering van artikel 32 VTSV niet voldoende voor bewijsuitsluiting. Voortaan wordt vereist dat het bewijs voorligt dat de onregelmatigheid de kwaliteit en de betrouwbaarheid van het bewijs daadwerkelijk heeft aangetast. ${ }^{159} \mathrm{Bij}$ de totstandkoming van de wet van 24 oktober 2013 in het parlement was de vraag aan de orde of de twee voormelde criteria - het bestaan van substantiële voorschriften die raken aan de organisatie van hoven en rechtbanken en een aantasting van de intrinsieke kwaliteit van het bewijs - al dan niet in de wettelijke regeling dienden te worden opgenomen doch zulks werd categorisch afgewezen. ${ }^{160}$

Indien er alsnog tot bewijsuitsluiting wordt overgegaan strekken de gevolgen van deze uitsluiting zich zoals voorheen nog steeds uit tot de vruchten van het onrechtmatig verkregen bewijs. Het gaat hierbij om het bewijs dat rechtstreeks of onrechtstreeks voortvloeit uit het primaire bewijs. ${ }^{161}$

De Belgische bewijsuitsluitingsregeling vond ondertussen ook al genade in de ogen van het EHRM. ${ }^{162}$

Aan dit alles moet nog worden toegevoegd dat volgens de rechtspraak een onderscheid dient te worden gemaakt tussen inlichtingen die toelaten een onderzoek te starten of te oriënteren enerzijds en het bewijs van de feiten anderzijds. De eerstbedoelde inlichtingen hebben geen bewijswaarde, ook al kunnen op die grond autonoom bewijzen worden vergaard. ${ }^{163}$ Het gebruik van onrechtmatig verkregen inlichtingen die niet dienen als bewijs maar louter worden aangewend ter oriëntering en voor de verdere uitbouw van een strafonderzoek leidt volgens het Hof van Cassatie niet tot de onontvankelijkheid van de strafvordering. Uit de tekst van artikel 32 Voorafgaande Titel Wetboek van Strafvordering en van artikel I3 van de wet van 9 december 2004 betreffende de wederzijdse internationale rechtshulp in strafzaken en tot wijziging van artikel goter Wetboek van Strafvordering volgt immers dat deze bepalingen niet van toepassing zijn op onregelmatig ver-

I58 Zie tevens Cass. I9 april 2016, T. Strafr. 2016, 366-369, met noot (i.v.m. de gevolgen van de vernietiging van art. 126 van de wet van 13 juni 2005 betreffende de elektronische communicatie door het Grondwettelijk Hof op de gegevens die op basis van een eerdere versie van deze wet werden bijgehouden).

I59 Cass. I4 mei 20I4, conclusie D. VAndermeErsCh, NC 20I5, 43-49, noot T. De Coster: "Over de toepassing van de Antigooncriteria op het zogenaamd 'wettelijk bewijs'. Een kroniek van een aangekondigde dood?".

r6o Zie in dit verband o.a. het verslag van de Commissie voor de Justitie van de Kamer: Parl. St. Kamer, 2012-I3, nr. 004I/OI5, waar de door de Senaat aangebrachte wijzigingen ongedaan werden gemaakt, en de daaraan voorafgaande parlementaire behandeling van het oorspronkelijke voorstel.

I6I J. MEESE, "Het bewijs in strafzaken" in P. TAELMAN (ed.), Efficiënt procederen voor een goede rechtsbedeling, XLIste Postuniversitaire cyclus Willy Delva, Mechelen, Kluwer, 20r6, 537.

I62 O.a. recent EHRM 3 I januari 20I7, Kalnéniené/België, T. Strafr. 20I7, II2- I2I, met noot C. VAN DE HeYNing, "Antigoon doorstaat ( voorlopig) de mensenrechtentoets".

I63 Cass. 5 februari 20I3, T. Strafr. 20I4, 55, noot F. SCHuERMAns. 
kregen inlichtingen die niet als bewijs in aanmerking kunnen worden genomen, maar louter worden aangewend ter oriëntering en voor de verdere uitbouw van een strafonderzoek. Dit ontslaat evenwel de rechter die vaststelt dat dergelijke inlichtingen onrechtmatig werden verkregen, niet van de verplichting na te gaan of het gebruik van die inlichtingen met dat doel het recht van de partijen op een eerlijk proces niet aantast, waarbij het eerlijk proces in zijn geheel moet worden beschouwd. ${ }^{164}$

De onrechtmatigheid die met het verkrijgen van dergelijke inlichtingen gepaard gaat, ontsnapt derhalve aan elke sanctionering binnen het strafproces aangezien de bewijsuitsluitingsregeling van artikel 32 VTSV eenvoudig niet toepasselijk is en buiten deze gevallen geen uitsluiting mogelijk is.

Wel werd geoordeeld dat onregelmatigheden die betrekking hebben op de ontvankelijkheid van de strafvordering kunnen niet worden beoordeeld aan de hand van de regels voor de beoordeling van onrechtmatig verkregen bewijs. ${ }^{165}$

\subsubsection{Toekomst}

Met MeEsE moet worden vastgesteld dat de Belgische bewijsuitsluitingsregel getuigt van een gebrek aan visie. Zulks heeft ook veel te maken met de wijze waarop de huidige regeling tot stand is gekomen, eerst via de rechtspraak en vervolgens zonder veel inhoudelijke discussie in het wetboek van strafvordering overgenomen. De wetgever heeft zich tot de dag van vandaag niet bezonnen over de zin van de bewijsuitsluiting en de voorschriften die dermate belangrijk zijn dat zij met bewijsuitsluiting dienen gesanctioneerd te worden. Het huidige wettelijk kader geeft ook zeer veel vrijheid aan de feitenrechter.

Bij het ontwerpen van een nieuwe regeling dient men zich te bezinnen over de oriëntatie ervan. MEESE merkt terecht op dat de Belgische uitsluitingsregel nogal individualistisch georiënteerd is. Hij leidt zulks af uit het feit dat de beslissing tot uitsluiting te maken heeft met de concrete strafzaak en dat aldus de indruk gewekt wordt dat de nietigheidsleer er enkel is om de rechten van de beklaagde te vrijwaren.

Dat de Belgische nietigheidsleer traditioneel opgevat is als een regeling die vertrekt vanuit de concrete strafzaak, is niet te loochenen. Het is ook denkbaar meer ruimte te geven aan overwegingen die betrekking hebben op een bredere maatschappelijke grondslag, met name het verzekeren van de rechtsstaat en het creëren van een samenleving waarin de burger gerust mag zijn dat overheidsoptreden dat interfereert in rechten en vrijheden enkel plaatsvindt binnen het democratisch tot stand gekomen wettelijk kader. ${ }^{166}$

I64 Cass. 28 februari 20I7, P.I6.026r.N; Cass. I8 april 2017, P.I6.I292.N.

I65 Cass. I9 januari 2016, P.I5.0768.N. In casu ging het om de machtiging van een aangifte wegens fiscale misdrijven overeenkomstig art. 29 Sv.

I66 J. MEESE, "Het bewijs in strafzaken" in P. TAELMAN (ed.), Efficiënt procederen voor een goede rechtsbedeling, XLIste Postuniversitaire cyclus Willy Delva, Mechelen, Kluwer, 20I6, 543. 
Dat van een uitsluitingsregel ook een signaal moet uitgaan naar de overheid en via deze weg de overheid eraan herinnerd moet worden wat in een democratische samenleving al dan niet toelaatbaar is, is zeker gewenst. Anderzijds ontkomt men niet aan de realiteit dat de vraag naar het lot van onrechtmatig verkregen bewijs concreet aan de orde gesteld wordt in een specifieke strafzaak en dat de te nemen beslissing over de bewijsuitsluiting noodzakelijk in die zaak dient te worden gekaderd. Dit rechtvaardigt dat ook in de toekomst nog een ruime plaats wordt voorbehouden voor criteria die in verband staan met de concrete strafzaak en de wijze waarop met de rechten van de beklaagde werd omgegaan.

Het huidige artikel 32 VTSV vertrekt van de idee dat elk onrechtmatig verkregen bewijs mag worden gebruikt tenzij in drie door de wet aangegeven gevallen. Het gebruik van onrechtmatig verkregen bewijs is aldus de regel en de uitsluiting ervan de uitzondering. Dit lijkt niet ideaal. In een rechtsstaat lijkt het aangewezen te vertrekken van het beginsel dat enkel van rechtsgeldig verkregen bewijs gebruik mag worden gemaakt en vervolgens een regeling uit te werken waarbij aangegeven wordt welke het lot is van het on rechtmatig bewijs.

In een toekomstige regeling van de bewijsuitsluiting zijn een aantal elementen die zouden kunnen meegenomen worden.

Vooreerst is het duidelijk dat elk bewijs dat werd bekomen als gevolg van een schending van artikel 3 EVRM dient te worden uitgesloten, evenals de gegevens die hierop steunen of daarvan zijn afgeleid.

Het lijkt ook duidelijk dat in navolging van de rechtspraak van het Hof van Cassatie $^{\mathrm{I} 67}$ moet worden aangenomen dat de vaststelling of de ontdekking van een misdrijf niet voor onbestaande kan worden gehouden. In dat geval komt het aan het Openbaar Ministerie toe om te oordelen welk gevolg hieraan wordt gegeven en of het mogelijk is rechtmatig bewijs in te zamelen.

De invoering van de onderzoeksrechter als machtigingsrechter vereist bovendien een bijzondere bescherming van zijn statuut. De regel dat in een geïntegreerd vooronderzoek onder leiding van het Openbaar Ministerie onderzoeksdaden die fundamentele rechten en vrijheden van burgers aantasten enkel ten uitvoer gelegd kunnen worden mits er een machtiging is door de onderzoeksrechter, is het sluitstuk van de nieuwe wettelijke regeling. Hieruit volgt dat de niet-naleving van deze regel streng dient te worden gesanctioneerd. Wanneer een onderzoeksdaad onderworpen is aan een machtiging van de onderzoeksrechter dienen de bewijzen die hierdoor werden verzameld uit de debatten te worden gesloten indien deze machtiging niet werd bekomen. Het spreekt voor zich dat een dergelijke situatie in een democratische rechtsstaat niet aanvaardbaar is. Deze situatie verschilt van de hypothese waarin een onrechtmatigheid wordt begaan bij de uitvoering van een onderzoeksdaad die geen machtiging van de onderzoeksrechter vereist of waarbij de politie een handeling stelt zonder toelating door het Open-

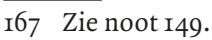


baar Ministerie. Omwille van de miskenning van een wettelijk vereiste machtiging van een rechter dient een strikte wettelijk verplichte uitsluitingsregel te worden toegepast waarbij geen ruimte meer gelaten wordt voor criteria die deze sanctie zouden afzwakken.

Buiten deze gevallen van wettelijk verplichte bewijsuitsluiting - waar weinig of geen ruimte voor rechterlijke relativering open staat - en de andere gevallen waar de wet een bijzondere regeling zou bepalen dienen de bewijzen die werden verkregen in strijd met het recht van verdediging, het recht op de bescherming van het privéleven, het recht op de integriteit van personen, de regels die de respectieve bevoegdheden van hoven en rechtbanken bepalen of het journalistiek bronnengeheim uit de debatten te worden geweerd, evenals de elementen die eruit zijn afgeleid. Hierbij zou de rechter nochtans anders kunnen oordelen en deze elementen toch in het dossier laten indien hij vaststelt dat (I) de onregelmatigheid niet de vrucht is van een bewuste of onverschoonbare schending van het beschermde recht, (2) de ernst van de schending van het beschermde recht of de beschermde waarde concreet minder zwaarwichtig is dan het maatschappelijk belang bij de vervolging van het betrokken misdrijf en de sanctionering van de dader en (3) het gebruik van het onrechtmatig verkregen bewijs geen afbreuk doet aan de integriteit van Justitie.

Andere onregelmatigheden die geen aantasting inhouden van de in de vorige paragraaf vermelde rechten zouden door de rechter aangewend kunnen worden. Niettemin wordt ook in dit geval een uitzondering gemaakt voor de hypothese waarbij het gebruik van dat bewijselement toch de integriteit van Justitie zou aantasten.

Aandacht dient ook te worden gegeven aan het onderscheid tussen de inlichtingen die toelaten een onderzoek te starten of te oriënteren enerzijds en degene die strekken tot het bewijs van de feiten anderzijds. Het gegeven dat bepaalde inlichtingen niet als een bewijs worden beschouwd en zodoende ontsnappen aan een rechterlijke controle in de zin van artikel 32 VTSV kan problematisch zijn. Indien de informatie door de rechter in zijn oordeelsvorming wordt betrokken of indien uit de bewijsconstructie en de motivering blijkt dat deze een rol heeft gespeeld bij de beslissing dient deze informatie aan hetzelfde regime als een bewijs te worden onderworpen. Om deze reden zou in een toekomstige wettelijke regeling de bredere term 'informatie' kunnen worden gebruikt in plaats van de klassieke term 'bewijs'.

De wetgever zal zich ook dienen te bezinnen over de vraag of er nog plaats is voor bewijsuitsluiting wanneer een bepaalde norm werd overtreden doch uit het dossier blijkt dat de beklaagde concreet niet in zijn rechten werd aangetast. Een minder individualistisch georiënteerde ratio van de bewijsuitsluiting, waarbij een groot belang wordt gehecht aan de integriteit van het justitieel apparaat, lijkt tegen een grote rol bij de bewijsuitsluiting voor een eis van belangenschade of een toepassing van de schutznormtheorie te pleiten. Er valt niet in te zien waarom de schending door de overheid van een wettelijke norm vanuit het oogpunt van de maatschappelijke grondslag van de bewijsuitsluiting minder gevolgen zou moeten hebben omdat de normschending in concreto niet geleid heeft tot een 
aantasting van de rechten van de beklaagde. De eerder 'private' grondslag van de bewijsuitsluiting pleit dan weer voor de tegengestelde oplossing.

Of andere sancties dan de uitsluiting van het onrechtmatig verkregen bewijs dienen te worden toegelaten lijkt niet zeker. Het lijkt moeilijk om een eenvormig mechanisme uit te werken waarbij een verhouding wordt vastgelegd tussen de ernst van de onregelmatigheid en de mate waarin strafvermindering dient te worden toegestaan. De analogie met de sanctionering van de overschrijding van de redelijke termijn overtuigt niet aangezien de door de overheid begane tekortkoming in beide gevallen moeilijk vergelijkbaar is. Hoogstens zou aan de rechter een dergelijke bevoegdheid kunnen worden verleend in de gevallen waarin het onrechtmatig verkregen bewijs niet wordt uitgesloten en op grond van de overweging dat toch een fout werd begaan.

\section{Io Besluit}

De hervorming van het strafprocesrecht is een dringende noodzaak geworden. Deze hervorming kan niet meer beperkt worden - zoals vroeger dikwijls het geval was - tot een voorzichtige en partiële herziening van bepaalde onderdelen van het Wetboek van Strafvordering. Meer dan tweehonderd jaar na de afkondiging van het huidige wetboek is het tijd om een debat te voeren over de grondslagen zelf van de strafprocedure. Het type vooronderzoek, de participatierechten van de partijen en de rol van de benadeelde persoon zijn slechts enkele aspecten die een grondige reflectie behoeven.

Hierbij is de wetgever aan zet. Er wacht het parlement geen gemakkelijke taak maar het ontwerpen van een leesbaar, coherent en evenwichtig wetboek van strafprocesrecht behoort nu eenmaal tot de kerntaken van de wetgever in een democratische rechtsstaat. 